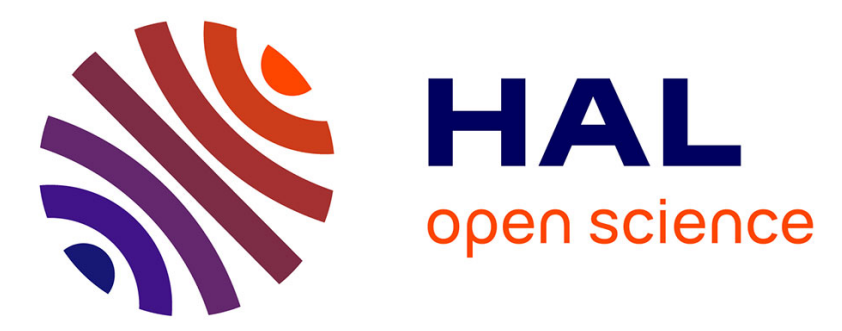

\title{
Antarctic-like temperature variations in the Tropical Andes recorded by glaciers and lakes during the last deglaciation
}

L. C P Martin, P.-H Blard, J Lavé, Vincent Jomelli, J. Charreau, T. Condom, M. Lupker, Maurice Arnold, Georges Aumaitre, D.L. L Bourlès, et al.

\section{To cite this version:}

L. C P Martin, P.-H Blard, J Lavé, Vincent Jomelli, J. Charreau, et al.. Antarctic-like temperature variations in the Tropical Andes recorded by glaciers and lakes during the last deglaciation. Quaternary Science Reviews, 2020, 247, pp.106542. 10.1016/j.quascirev.2020.106542 . hal-03029770

\section{HAL Id: hal-03029770 \\ https://hal.univ-lorraine.fr/hal-03029770}

Submitted on 2 Dec 2020

HAL is a multi-disciplinary open access archive for the deposit and dissemination of scientific research documents, whether they are published or not. The documents may come from teaching and research institutions in France or abroad, or from public or private research centers.
L'archive ouverte pluridisciplinaire HAL, est destinée au dépôt et à la diffusion de documents scientifiques de niveau recherche, publiés ou non, émanant des établissements d'enseignement et de recherche français ou étrangers, des laboratoires publics ou privés.

\section{(ㅇ)(1) $\$$}

Distributed under a Creative Commons Attribution - NonCommercial - NoDerivatives| 4.0 


\section{Antarctic-like temperature variations in the Tropical Andes 2 recorded by glaciers and lakes during the last deglaciation}

3 L.C.P. Martin ${ }^{\mathrm{a}, \mathrm{b}^{*}}$, P.-H. Blard ${ }^{\mathrm{a}, \mathrm{c}^{*}}$, J. Lavé, ${ }^{\mathrm{a}}$, V. Jomelli, ${ }^{\mathrm{d}, \mathrm{e}}$, J. Charreau ${ }^{\mathrm{a}}$, T. Condom ${ }^{\mathrm{f}}$, M. Lupker ${ }^{\mathrm{g}}$,

4 ASTER Team ${ }^{\text {e\# }}$

leo.doug.martin@gmail.com; blard@.crpg.cnrs-nancy.fr Centre de Recherches Pétrographiques et Géochimiques

15 rue Notre Dame des Pauvres 54501 Vandœuvre-lès-Nancy

France

- Words: 14,986

- Tables: 7

- Figures: 18

- Supplementary Information: 1,247 words, 3 Tables,4 figures

Keywords: paleoclimate dynamics; Tropical Andes; paleoglaciers; cosmogenic nuclides; ${ }^{10} \mathrm{Be},{ }^{3} \mathrm{He}$; glacial geomorphology; last deglaciation; Termination 1; continental paleotemperature and precipitation reconstruction, global and regional climate. 


\section{$28 \quad$ Highlights}

29 - Cosmic ray exposure ages and paleo-ELAs determined for Bolivian Andes late-glacial moraines

30 - New ${ }^{14} \mathrm{C}$ shoreline ages constrain the depth of paleolake Coipasa $(\sim 12.5 \mathrm{cal}$ kyr BP $)$

31 - Temperature and precipitation reconstructed from coupled glacier-lake modeling

32 - Lake-induced precipitation recycling effect accounted in reconstruction

33 - Precipitation modulated by Northern Hemisphere, temperatures by Antarctic during 19-11 ka BP

\section{Abstract}

The respective impacts of Northern and Southern Hemispheric climatic changes on the Tropics during the last deglaciation remain poorly understood. In the High Tropical Andes, the Antarctic Cold Reversal (ACR, 14.3-12.9 ka BP) is better represented among morainic records than the Younger Dryas (12.9-11.7 ka BP). However, in the Altiplano basin (Bolivia), two cold periods of the Northern Hemisphere (Heinrich Stadial 1a, 16.5-14.5 ka BP, and the Younger Dryas) are synchronous with (i) major advances or standstills of paleoglaciers and (ii) the highstands of giant paleolakes Tauca and Coipasa.

Here, we present new cosmic ray exposure (CRE) ages from glacial landforms of the Bolivian Andes that formed during the last deglaciation (Termination 1). We reconstruct the equilibrium line altitudes (ELA) associated with each moraine and use them in an inverse algorithm combining paleoglaciers and paleolake budgets to derive temperature and precipitation during the last deglaciation. progressive warming from $\Delta \mathrm{T}=-5$ to $-2.5^{\circ} \mathrm{C}$ during $17-14.5 \mathrm{ka} \mathrm{BP}$, followed by a return to colder conditions around $-4^{\circ} \mathrm{C}$ during the ACR (14.5-12.9 ka BP). The Coipasa highstand (12.9-11.8 ka BP) is coeval with another warming trend followed by $\Delta \mathrm{T}$ stabilization at the onset of the Holocene (ca. 10 ka BP), around $-3^{\circ} \mathrm{C}$. Our results suggest that, during the last deglaciation $(20-10 \mathrm{ka} \mathrm{BP})$ atmospheric

51 temperatures in the Tropical Andes mimicked Antarctic variability, whereas precipitation over the 52 Altiplano was driven by changes in the Northern Hemisphere. 


\section{Introduction}

The last deglaciation was characterized by major reorganizations of the continental and oceanic climate systems, including modifications of oceanic circulations (McManus et al., 2004), and the monsoon systems (Cruz et al., 2005), shifts of the wind belts (Denton et al., 2010; Toggweiler, 2009), and opposing north/south temperature variations (Barker et al., 2009; Broecker, 1998). During this period, antiphase warming/cooling events (such as the Northern Hemisphere, NH, warm BøllingAllerød and the Southern Hemisphere, SH, Antarctic Cold Reversal, Andersen et al., 2004; Jouzel et al., 2007) may have influenced both hemispheres and triggered major continental hydro-climatic changes (e.g. Barker et al., 2011; Blard et al., 2011a, 2009; Broecker and Putnam, 2012; Jomelli et al., 2014; Martin et al., 2018; Placzek et al., 2006; Sylvestre et al., 1999). However, the respective interhemispheric impacts of oceanic and atmospheric changes remain controversial and the subject of various investigations (e.g. Blard et al., 2009; Fritz et al., 2007; Jomelli et al., 2014).

Because the tropics are intersectional between the Northern and Southern Hemispheres, this region is key to addressing the respective impacts of both hemispheres on global and regional climates (Jackson et al., 2019). The Tropical Andes, and particularly the Altiplano Basin, exhibit outstanding hydro-climatic archives of climatic changes during the last deglaciation. Indeed, the Antarctic Cold Reversal (a SH event) was reported to have exerted a major influence on glacial dynamics throughout the tropical and sub-tropical Andes (Jomelli et al., 2014). Furthermore, in the Altiplano, paleohighstands of Lakes Tauca $\left(52,000 \mathrm{~km}^{2}\right)$ and Coipasa $\left(32,000 \mathrm{~km}^{2}\right)$ are synchronous with the second half of the Heinrich Stadial 1 (16.5 - 14.5 ka BP) and the Younger Dryas (12.9 - $11.7 \mathrm{ka}$ BP), respectively (NH events, Blard et al., 2011a; Placzek et al., 2006; Sylvestre et al., 1999). These lake cycles are characterized by abrupt transgressions and regressions within $1 \mathrm{kyr}$, implying drastic and fast climatic changes that occurred synchronously with abrupt changes within the northern Atlantic region (Andersen et al., 2004; McManus et al., 2004). Throughout the Altiplano Basin, moraine records evidence glacial standstills or re-advances synchronous with the Lake Tauca highstand, which Martin et al. (2018) used to reconstruct the regional distribution of precipitation during Heinrich Stadial 1 (16.5 $-14.5 \mathrm{ka} \mathrm{BP}$ ), for which they computed a regional precipitation increase of $130 \%$ (i.e. a factor of 2.3 ). 
Relying on their reconstructed spatial distribution of precipitation, they concluded that the change in rainfall regime during Heinrich Stadial 1 resulted from modifications of the South American Summer Monsoon (SASM), involving a southward shift of synoptic atmospheric features compared to the present.

Numerous studies have provided local chronologies of glaciers fluctuations in the tropical Andes for the last glacial maximum (LGM) and late-glacial period (e.g. Bromley et al., 2016; Carcaillet et al., 2013; Farber et al., 2005; Palacios et al., 2020; Shakun et al., 2015; Smith, 2005; Ward et al., 2015; Zech et al., 2009) and climatic reconstructions from glacial landforms in the vicinity of the Altiplano have already been reported (Jomelli et al., 2011; 2016, Kull et al.,, 2008; Kull and Grosjean, 2000; Malone et al., 2015). In the Altiplano, Blard et al. (2009) and Placzek et al. (2013) quantified temperature variations based on joint lake- and glacier-budget calculations during the Lake Tauca cycle. However, these previous approaches suffered from substantial uncertainties on the spatial distribution of precipitation over the Altiplano because very few climatic reconstructions are available before and after the Lake Tauca highstand. Notably, little is known about Tropical Andean temperatures and precipitation during the LGM-Heinrich 1 transition, the ACR and the Younger Dryas. In this regard, climatic reconstructions spanning the last deglaciation in the High Tropical Andes are critical to establishing the extent and influence of these major and potentially opposing climatic changes recorded at high latitudes of the Northern and Southern Hemisphere.

Here we present new glacial chronologies from four sites of the Bolivian Altiplano: the Zongo valley $\left(16.3^{\circ} \mathrm{S}, 68.1^{\circ} \mathrm{W}\right)$, Nevado Sajama $\left(18.1^{\circ} \mathrm{S}, 68.9^{\circ} \mathrm{W}\right)$, Cerro Tunupa $\left(19.8^{\circ} \mathrm{S}, 67.6^{\circ} \mathrm{W}\right)$, and Cerro Luxar $\left(21.0^{\circ} \mathrm{S}, 68.0^{\circ} \mathrm{W}\right)$. These chronologies are based on cosmic ray exposure (CRE) dating of recessional moraine sequences and glacially abraded bedrock surfaces. These new data extend the existing chronologies of Smith et al. (2005), Jomelli et al. (2011), Blard et al. (2009, 2013) and Martin et al. (2018). Considering lake-level variations over the same period, we applied an inversion method that builds on our previous studies (Blard et al. 2009, Martin et al. 2018). By coupling glacier- and lake-

105 budget calculations, we took advantage of their contrasting sensitivities to temperature and precipitation, and reconstructed temperature and precipitation ranges that jointly satisfy glacial and lacustrine extents for a given moment of the last deglaciation. 


\section{Geological Setting}

\subsection{Climate of the Altiplano}

The Altiplano is a wide intra-mountain plateau covering an area of $196,000 \mathrm{~km}^{2}$ and bounded

111 by the eastern and western Andes Cordilleras (Fig. 1). Due to its regional topography, this area is an

112 endorheic basin (hereafter, the "Altiplano Basin"). This basin extends from $15.5^{\circ} \mathrm{S}$ (Peru) to $22.5^{\circ} \mathrm{S}$

113 (Bolivia), and ranges in elevation from 3,658 $\mathrm{m}$ above sea level (asl) at Salar de Uyuni to 6,542 $\mathrm{m}$ asl

114 at Sajama volcano.

115 The precipitation regime of the Altiplano is under the climatic influence of the SASM, which

116 brings most of the annual rainfall during the austral summer (December, January, February, Vera et al.,

117 2006; Zhou and Lau, 1998). During this period, the dry westerlies are weakened by subtropical jet

118 modulations and a concomitant southward expansion of the tropical easterlies. This modification

119 promotes the transport of humidity from the Amazonian basin and central Brazil towards the Altiplano

120 (Garreaud et al., 2003, 2009; Segura et al., 2019; Vuille, 1999; Vuille and Keimig, 2004). The

121 orographic effect of the Eastern Cordillera modulates this transport and creates an important precipitation gradient over the Altiplano. Annual rainfall presently ranges from $800 \mathrm{~mm}$ on the shores

123 of Lake Titicaca to $60 \mathrm{~mm}$ in the vicinity of the Laguna Colorada, southwest Bolivia (Fig. 1).

124 Present temperatures are relatively uniform over the Altiplano, and the daily temperature 125 variability is larger than the seasonal variability (Aceituno, 1996) as is often observed in the tropics

126 (Hastenrath, 1991). Maximum daily temperatures occur around $2 \mathrm{pm} \mathrm{LT}$ when solar radiation is 127 maximal. For most of the year, daily temperature variations are constrained by night radiative loss from 128 the surface. Therefore, the daily amplitude of temperature variations is reduced during the wet season 129 when cloudiness is important (Condom, 2002). Climatic conditions at the glacial sites are presented in 130 Table 1. 

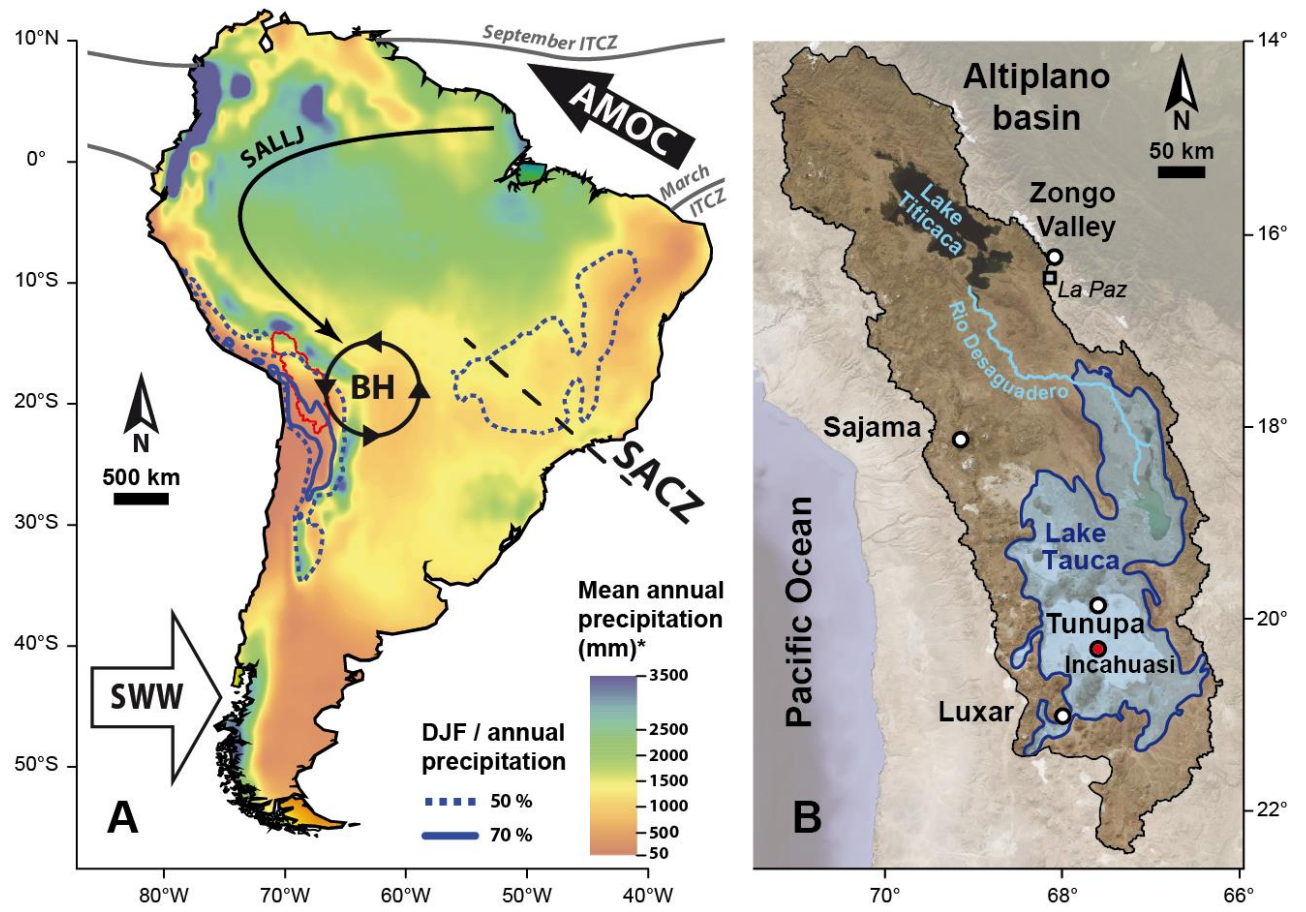

Figure 1. South American climate and the Altiplano Basin. (A) Modern features of the South American climate, with particular focus on the summer monsoon. $S W W$, southern westerly winds; AMOC, Atlantic meridional overturning circulation; ITCZ, intertropical convergence zone; SALLJ, South American low-level jets; SACZ, South Atlantic convergence zone; BH, Bolivian High. The colored background indicates mean annual rainfall (*color scale truncated at 3,500 mm). Blue contours show the December-February (DJF) to annual precipitation ratio. Precipitation data are mean values during 1979-2016 from ERA-Interim (Dee et al., 2011). (B) The Altiplano Basin and the locations of sites analyzed herein overlaid on SPOT Imagery. White dots indicate glacial valleys, and the red dot indicates lacustrine deposits sampled and analyzed herein. The maximum paleo-extent of Lake Tauca is shaded in blue. The black line delimits the Altiplano endorheic basin.

\subsection{Altiplano hydrology and paleolake records}

The Altiplano endorheic basin comprises a north-south succession of four adjacent sub-basins

(Fig. 2). The Titicaca watershed in the northern Altiplano is the highest (lake altitude, 3,812 $\mathrm{m}$ asl) and wettest sub-basin. It drains to the southeast via Rio Desaguadero (Figs. 1 and 2) to the Poopo watershed. Lake Poopo was a shallow lake $(<3 \mathrm{~m}$ deep) that vanished in 2015 due to ongoing climate change and excessive irrigation (Satgé et al., 2017). The small Coipasa watershed is to the southwest of Poopo watershed, and the two are separated by an elevation threshold of 3,703 $\mathrm{m}$ asl (Fig. 2). The Uyuni watershed (bottom at 3,660 m asl) is to the south of Coipasa watershed, from which it is separated by an elevation threshold of 3,672 $\mathrm{m}$ asl. Channels and paleochannels between the different basins indicate

that they were hydrologically connected during wetter periods. 


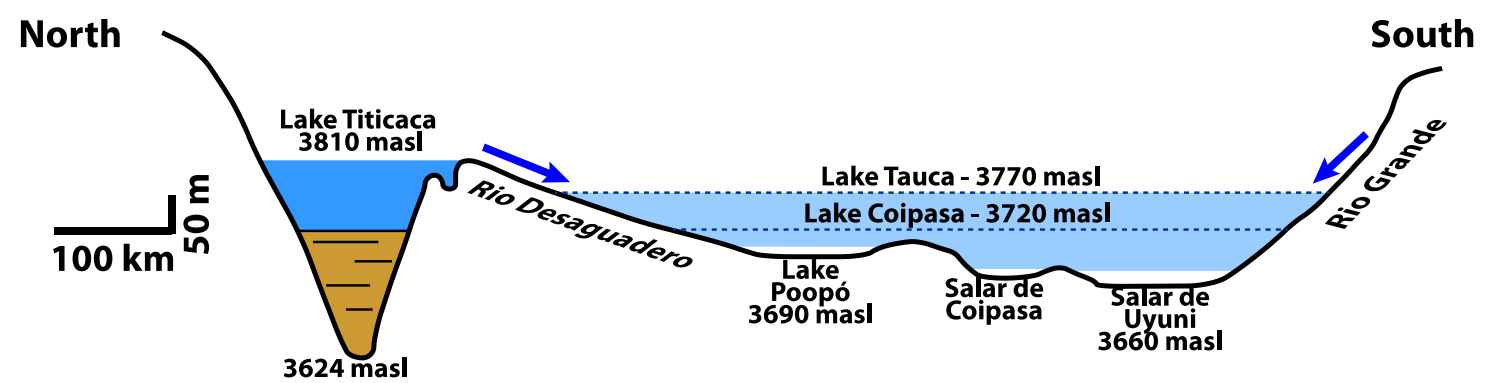

153

154

155

156

157

158

159

160

161

162

163

164

165

166

167

168

169

170

Figure 2. Topographic cross section of the Altiplano showing the hydrological relationships between lake and salar watersheds (modified from Argollo and Mourguiart, 2000). The threshold between the Poopo and Coipasa watersheds is 3,703 m asl. The threshold between the Coipasa and Uyuni watersheds is 3,672 $\mathrm{m}$ asl. The elevation reported for paleolake Coipasa is based on our new shoreline ${ }^{14} \mathrm{C}$ ages (see Section 4.1.1).

The three southernmost basins of the Altiplano are dry at present, but were covered by large lakes during the wettest periods of the Quaternary (Placzek et al., 2006; Sylvestre et al., 1999). Of the several lake episodes that occurred during the last $120 \mathrm{kyr}$, the Lake Tauca episode was the widest and deepest ( 110 to $120 \mathrm{~m}$ deep, Placzek et al., 2006; Blard et al., 2011). During the Lake Tauca highstand $(3,770 \mathrm{~m}$ asl), the lake extent covered the totality of the three southernmost basins (Poopo, Coipasa and Uyuni; Figs. 1 and 2).

$\mathrm{U}-\mathrm{Th}$ and ${ }^{14} \mathrm{C}$ dating of its shorelines constrain the timing of the Lake Tauca cycle, i.e. the transgression (18-16.5 ka BP), highstand (16.5-15.5 ka BP) and regression phases (14.5-13.5 ka BP, Blard et al., 2013a). During its highstand, the lake level reached a maximum altitude of 3,770 $\mathrm{m}$ asl and covered $52,000 \mathrm{~km}^{2}$. The Coipasa Lake cycle is characterized by a transgression from 13.3 to $12.9 \mathrm{ka}$ $\mathrm{BP}$, a highstand from 12.9 to $11.8 \mathrm{ka} \mathrm{BP}$ and a regression from 11.8 to $10.2 \mathrm{ka} \mathrm{BP}$ (Blard et al., 2011a; Placzek et al., 2006; Sylvestre et al., 1999). Placzek et al. (2013) reported that the highstand lake level reached 3,700 $\mathrm{m}$ asl, covering $28400 \mathrm{~km}^{2}$.

To expand the existing age dataset, we sampled two new bioherms on Isla Incahuasi $\left(20.24^{\circ} \mathrm{S}\right.$ $67.62^{\circ} \mathrm{W}$, Table 2), a rocky hill in the center of Salar de Uyuni (Fig. 3). The first bioherm lies $5 \mathrm{~m}$ below the top of the hill (3,715 masl). Dislocations in the calcareous crust revealed a radial cross section of its cortical structure. We took advantage of this exposure and sampled the outermost cortex (INC-13-1), which presents a fine radial branching structure, and a more inner region of the bioherm (INC-13-2), 
178 hill (3,720 $\mathrm{m}$ asl), and we sampled the outermost cortex (INC-13-3).
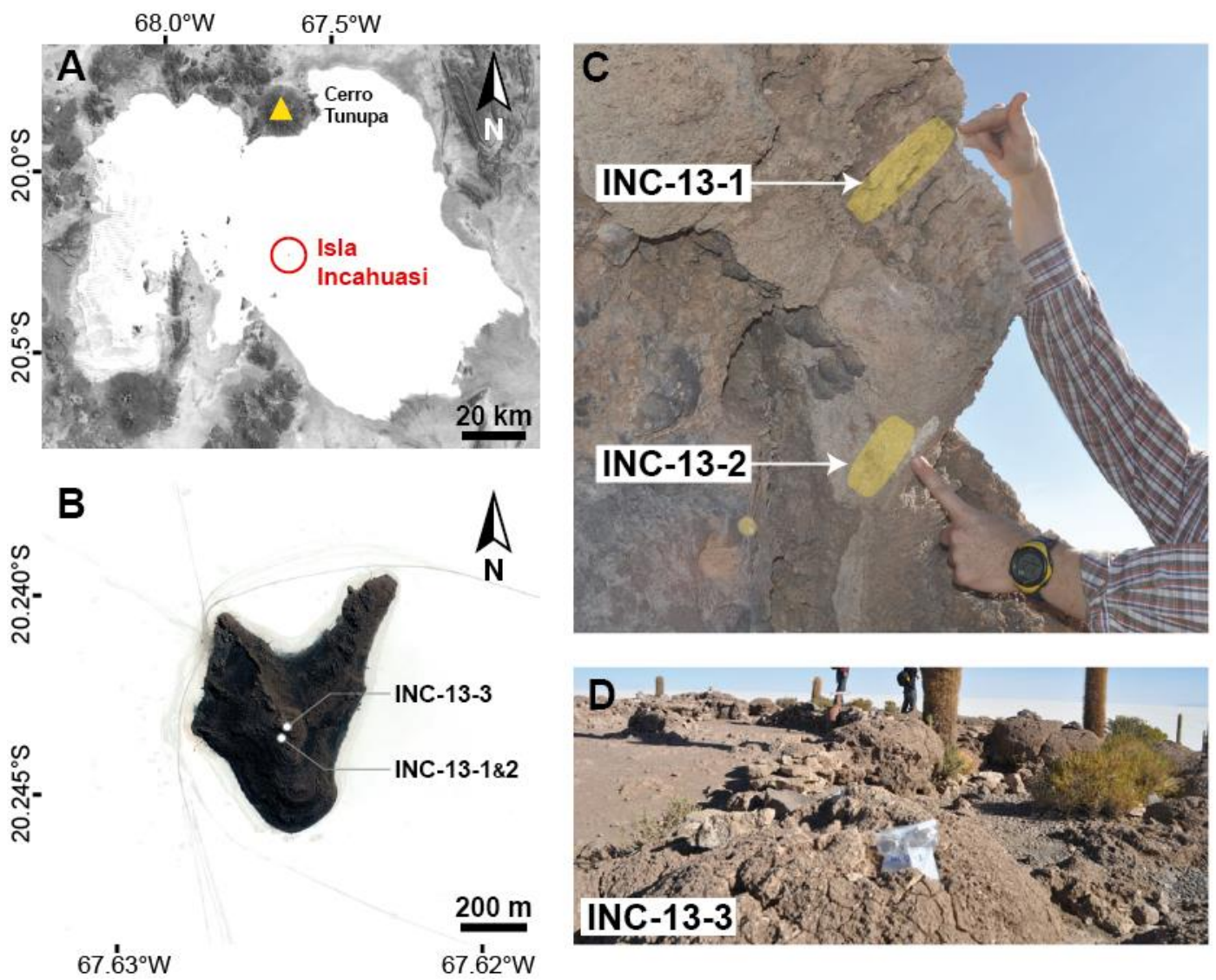

Figure 3. Bioherm samples on Isla Incahuasi. (A) The location of Isla Incahuasi within Salar de Uyuni. (B) Bioherm sampling locations on Isla Incahuasi. (C) INC-13-1 and INC-13-2 sample different parts of the same bioherm; yellow shaded areas indicate the sampled portions of the bioherm. (D) Sample INC-13-3 atop the hill.

\subsection{Moraine Settings}

The four paleoglaciated sites presented in this study span the latitudinal range from $16.3^{\circ} \mathrm{S}$ to $21.0^{\circ} \mathrm{S}$ (Fig. 1).

\subsubsection{Zongo Valley $\left(16.2^{\circ} \mathrm{S}-68.1^{\circ} \mathrm{W}\right)$}

Zongo valley is in the Cordillera Real in the northern part of the Bolivian Altiplano (Fig. 1). It is a northward-orientated valley, draining a mountainous area of about $150 \mathrm{~km}^{2}$ towards the Amazonian basin and culminating at Huayna Potosi $(6,088 \mathrm{~m}$ asl). Presently glaciated areas have small extents. Huayna Potosi presently bears a retreating slope glacier on its southern face which has been monitored by the IRD-GREAT ICE team since 1991 (Rabatel et al., 2013; Soruco et al., 2009). Other summits in 
194 the valley (Telata, Charquini) only bear small glaciers or perennial snow patches. The valley exhibits

195 geomorphic evidence of important past glaciations including several moraines and roches moutonnées.

196 This part of the Cordillera Real massif mainly comprises granitic rocks. The glacial geomorphic features 197 of Zongo Valley are thus suitable for CRE dating by measuring ${ }^{10} \mathrm{Be}$ in quartz. Such data have already 198 been reported for this valley (Jomelli et al., 2011; Martin et al., 2018; Smith et al., 2005). We sampled 19923 new moraine boulders and combined our and previous results to better constrain the timing of the 200 deglaciation in the valley (Fig. 4, Table 3). The different moraines are classified into four groups. The Cerro Illampu group (green moraines on Fig. 4) includes the five most distal moraines (IP1 to 5) and a perched frontal moraine left by a small glacier of local origin (IP $\alpha$ ). Moraines IP1 to 5 are LGM moraines studied by Smith et al. (2005) and Martin et al. (2018). Downstream from these moraines, glacial morphologies vanish and the U-shaped valley gradually becomes V-shaped, indicating the former extent of past glacial activities. IP1 to 3 are 206 lateral moraines and IP4 and 5 are frontal moraines in the bottom of the valley. Due to their distal 207 position in the valley, the former ice tongues associated with moraines IP1 to 3 resulted from the 208 convergence of 5 ice streams flowing down from Huayna Potosi, Charquini, Telata, Cerro Illampu and 209 Jiskha Choquela (Fig. 4A). The IP 4 and 5 ice tongues flowed from the Cerro Illampu summit alone. The Main Valley (MV) moraine gathers a complex of small recessional (lateral and frontal) 211 moraines that lie upstream within a portion of the Zongo valley that flows straight north (Fig. 4A). The 212 associated ice tongue resulted from the convergence of ice flows from Huayna Potosi, Cerro Charquini 213 and Cerro Telata. The T1 to T3 moraines are associated with ice flows downstream from Cerro Telata. 214 These sets of frontal moraines were dated to the Pleistocene - Holocene transition by Jomelli et al. 215 (2011). CQ1 and CQ3 are lateral moraines and CQ4 is a frontal moraine. Whereas the ice tongue 216 associated with CQ1 must have resulted from the convergence of ice streams from Huayna Potosi and 217 Charquini, CQ3 and CQ4 are only associated with downstream ice flows from Cerro Charquini. The 218 MV and CQ moraines were sampled for the present study (see Table 3). From IP1 to CQ4, the glacial 219 record spans over $15 \mathrm{~km}$ horizontally and over $1200 \mathrm{~m}$ vertically. Examples of collected samples are 220 shown on Fig. 5. 

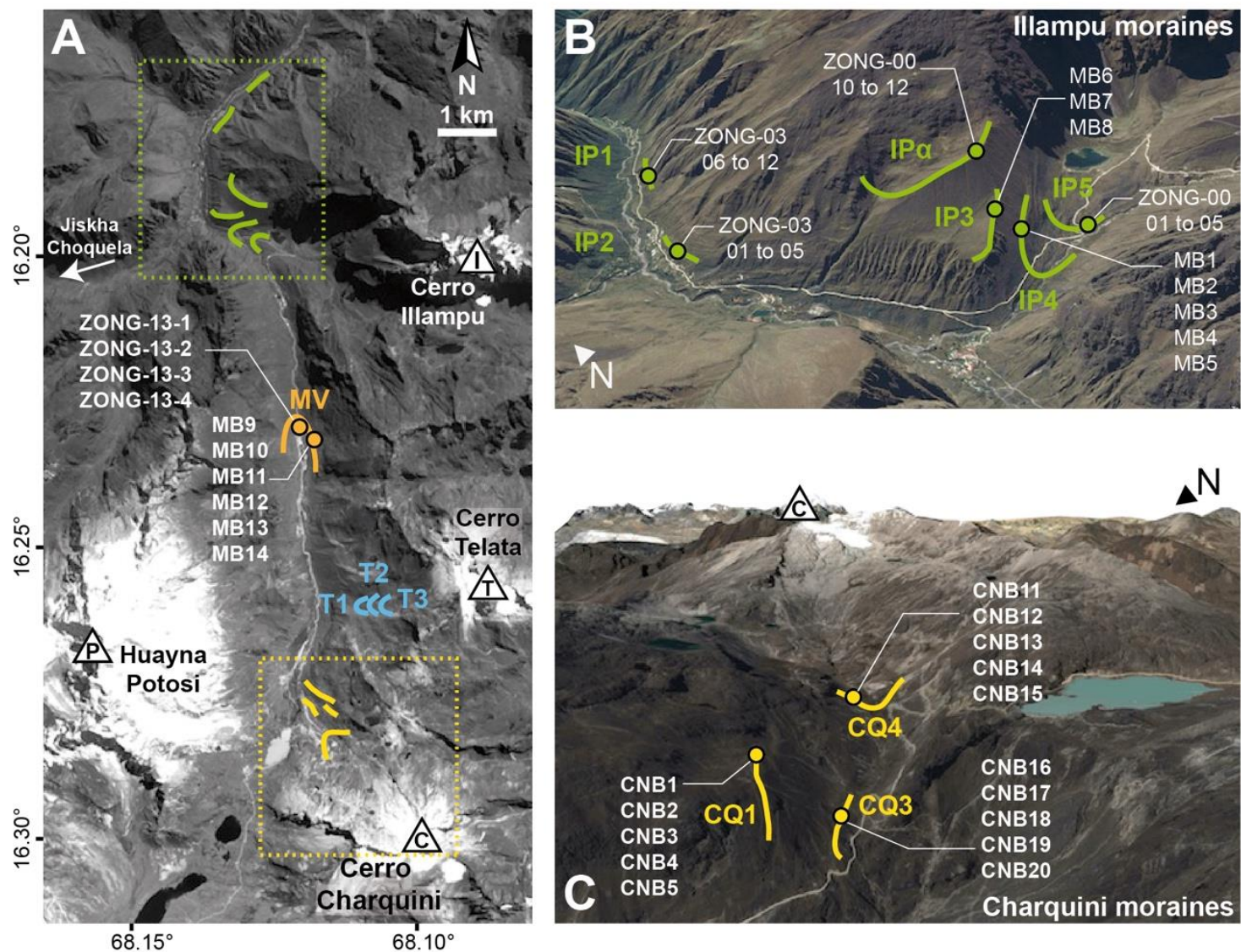

Figure 4. Moraine samples in Zongo Valley. (A) Overview of moraine groups and samples. (B) Cerro

Illampu moraines (sample numbers from Smith et al., 2005 and Martin et al., 2018). (C) Charquini moraines. Sample names in bold font are original samples from this study (MV and CQ groups). Samples from the T moraine group (blue) are from Jomelli et al. (2011), and are not detailed here (see Table 3).
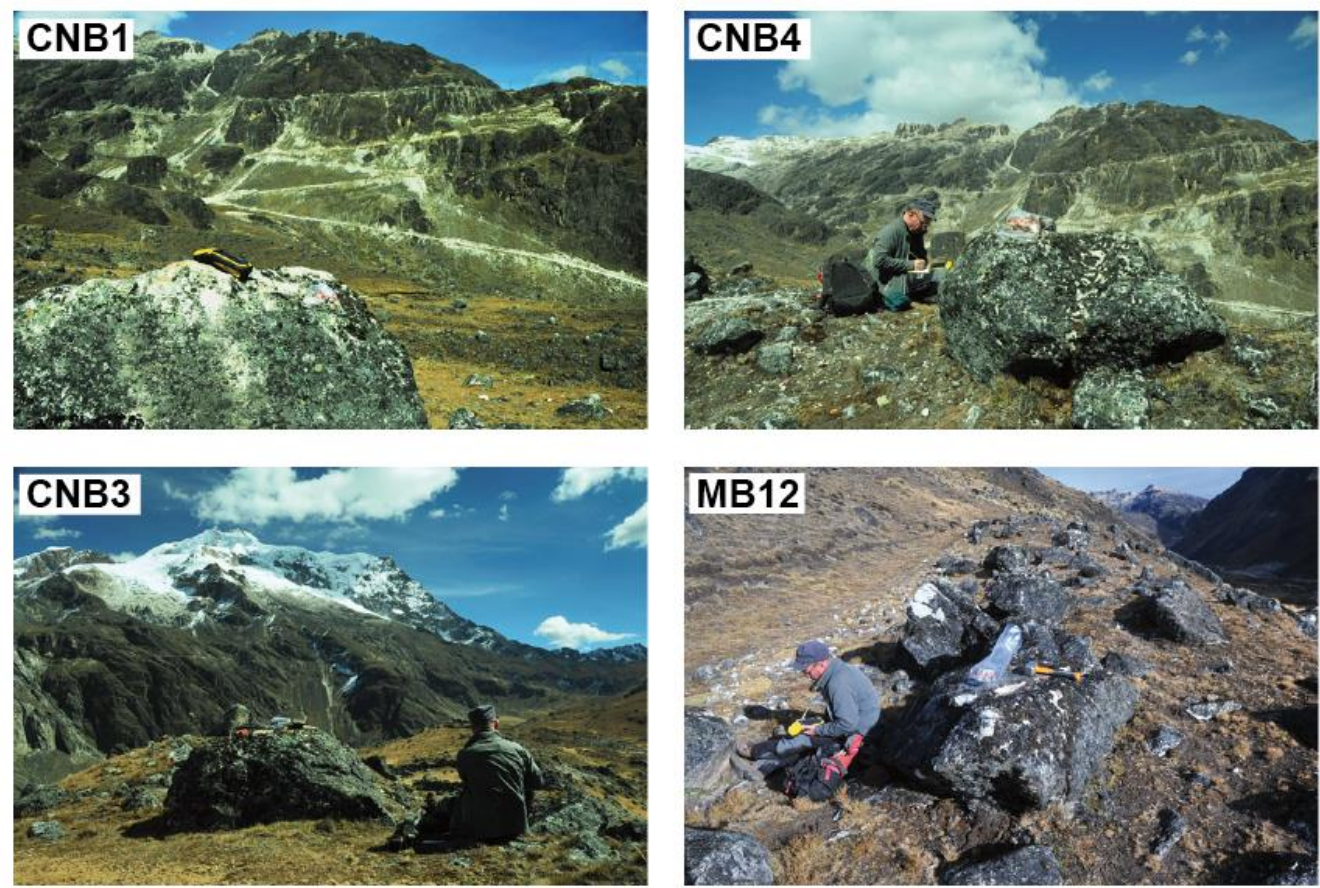

Figure 5. Examples of sampled boulders in Zongo Valley. Samples shown here belong to the CQ1 
Nevado Sajama is an andesitic and rhyodacitic stratovolcano in the western part of the central

231 Altiplano, and the highest summit of Bolivia (6,542 $\mathrm{m}$ asl). Nevado Sajama presently bears a small ice

232 cap of $\sim 5 \mathrm{~km}^{2}$ spanning $5,500-6,500 \mathrm{~m}$ asl. Larger past glacial activities carved numerous glacial valleys

233 into the flanks of the volcano radiating from the summit. We collected 18 samples on four moraines and

234 three roches moutonnées in the main southward valley of Nevado Sajama, where a former glacier left a

235 prominent moraine and smaller cordons (Fig. 6). The M1 moraine was CRE dated ( ${ }^{3} \mathrm{He}$ in pyroxenes)

236 at $15.1 \pm 1.1 \mathrm{ka}$ BP by Martin et al. (2018).
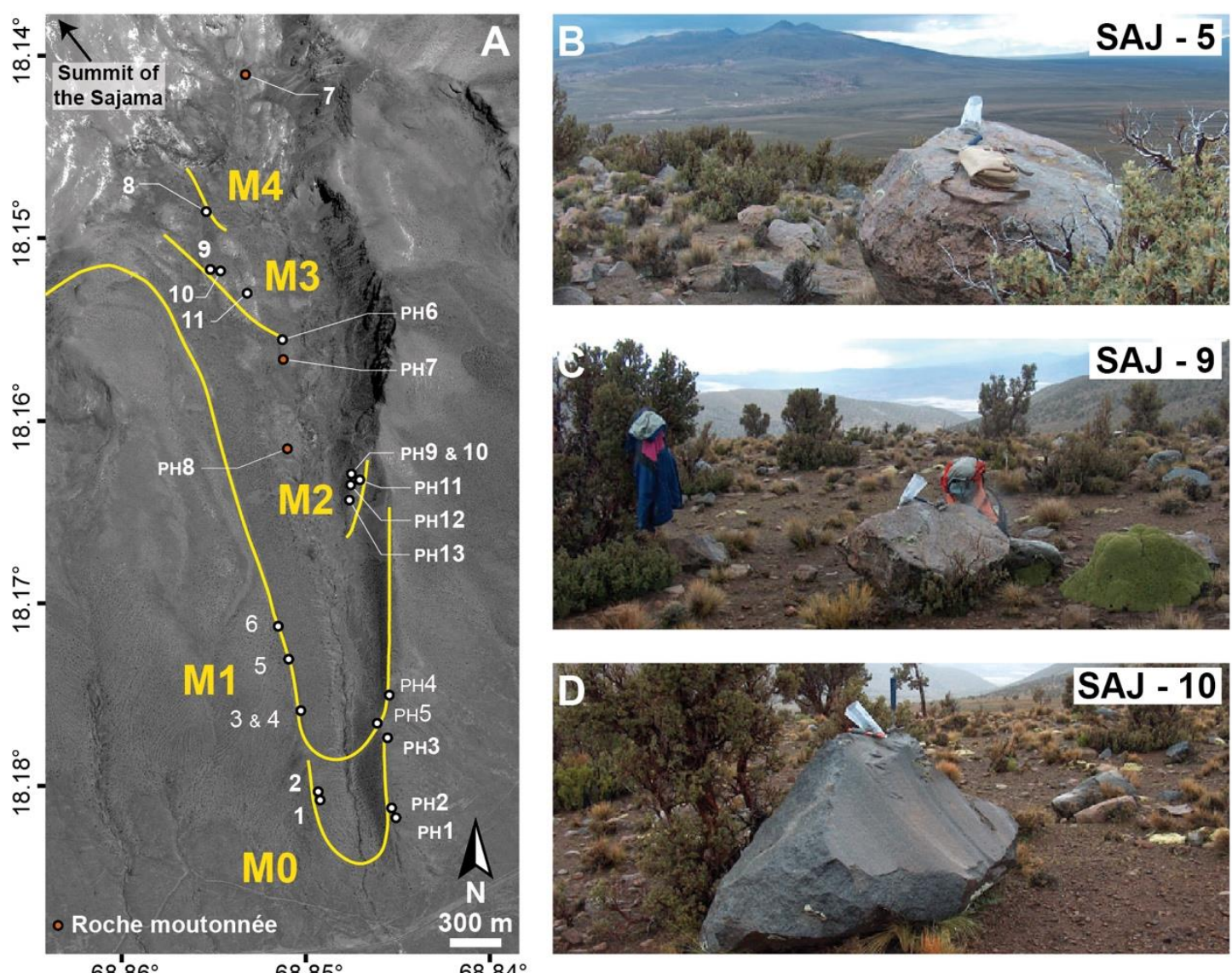

Figure 6. Moraine and roche moutonnée samples in the main southward valley of Nevado Sajama. (A) Detailed samplings of each moraine. White and orange dots indicate morainic boulder and roches moutonnées samples, respectively. Solid yellow lines delimit the moraines in the main scope of this study. Full sample names include the prefix 'SAJ-'. Only samples listed in bold font are from this study (i.e. all samples except those from M1, which are from Martin et al., 2018). (B-D) Representative morainic boulder samples.

Terminal moraine M0 was formed by the maximal ice extent in the valley, and M1-4 are recessional moraines deposited subsequently. These moraines lie in the bottom part of the valley, towards the southwest. The terminus of M1 is $700 \mathrm{~m}$ upstream from that of M0 (horizontal distance); 
248 M1 is more sharp-crested than M0 and was built laterally atop M0 lateral moraines. Recessional 249 moraines M2 and M3 are probably associated with short standstills as they are much smaller than M1. 250 Additionally, the geometry of M3 suggests a narrower ice flow associated with a reduced upstream 251 accumulation area (Fig. 6). Two roches moutonnées were sampled between M2 and M3 (SAJ-PH7 and 252 SAJ-PH8) and another upstream of M4 (SAJ-7). This glacial record spans over 5 km horizontally and 253 over $300 \mathrm{~m}$ vertically. The andesitic composition of the samples led us to establish CRE ages from in254 situ cosmogenic ${ }^{3} \mathrm{He}$ concentrations in pyroxenes. CRE ${ }^{36} \mathrm{Cl}$ ages reported by Smith et al. (2009) for the 255 eastward valleys of Nevado Sajama indicate late-glacial and Holocene moraines. Scatter among their 256 samples from the late-glacial period precludes a precise chronology.

\subsubsection{Cerro Tunupa $\left(19.8^{\circ} \mathrm{S}-67.6^{\circ} \mathrm{W}\right)$}

Cerro Tunupa (summit elevation, 5,321 m asl) is an andesitic stratovolcano in the center of the southern Altiplano, above the northern edge of Salar de Uyuni. Cerro Tunupa does not presently bear permanent ice cover, although numerous glacial landforms are preserved in its southern flank (Blard et al., 2009; Clayton and Clapperton, 1997). Chalchala valley is the main glacial valley, extending from

262 the glacial cirque towards the southeast. Downstream, the glacial carving gradually disappears and the 263 valley widens on the Chalchala glacial fan (Fig. 7). In this valley, Blard et al. (2009, 2013a) studied four 264 moraines (M0-3) and the Chalchala fan delta (Fig. 7). M0 is a pre-LGM moraine outlet cross-cut by moraine M1. M1 and M2 have cosmogenic ${ }^{3} \mathrm{He}$ exposure ages contemporaneous with the Lake Tauca highstand (Blard et al., 2009, 2013a). Martin et al. (2018) recalculated the age of M2 to be $15.7 \pm 0.6$

267 ka BP based on the data of Blard et al. (2009) and additional Bayesian conditions based on the upper268 lying roche moutonnées TU-2 and TU-4. The recession indicated by M3 was dated to $14.5 \mathrm{ka}$ BP by 269 Blard et al. $(2009,2013)$.

As shown on Fig. 7, the lateral part of M2 was sampled but evidence of its frontal part remains unclear. The M3 moraine complex corresponds to small ice tongues that stood as the downstream digitations of a small-extent cirque glacier. A complete description of the Chalchala moraines is

273 available in Blard et al. (2009). Samples from the Chalchala valley span over $400 \mathrm{~m}$ vertically and $4 \mathrm{~km}$ 274 horizontally. 
276 roches moutonnées and six new morainic boulders (sample names including "13"). These samples were

277 collected for CRE age determinations from in-situ ${ }^{3} \mathrm{He}$ concentrations in pyroxenes.

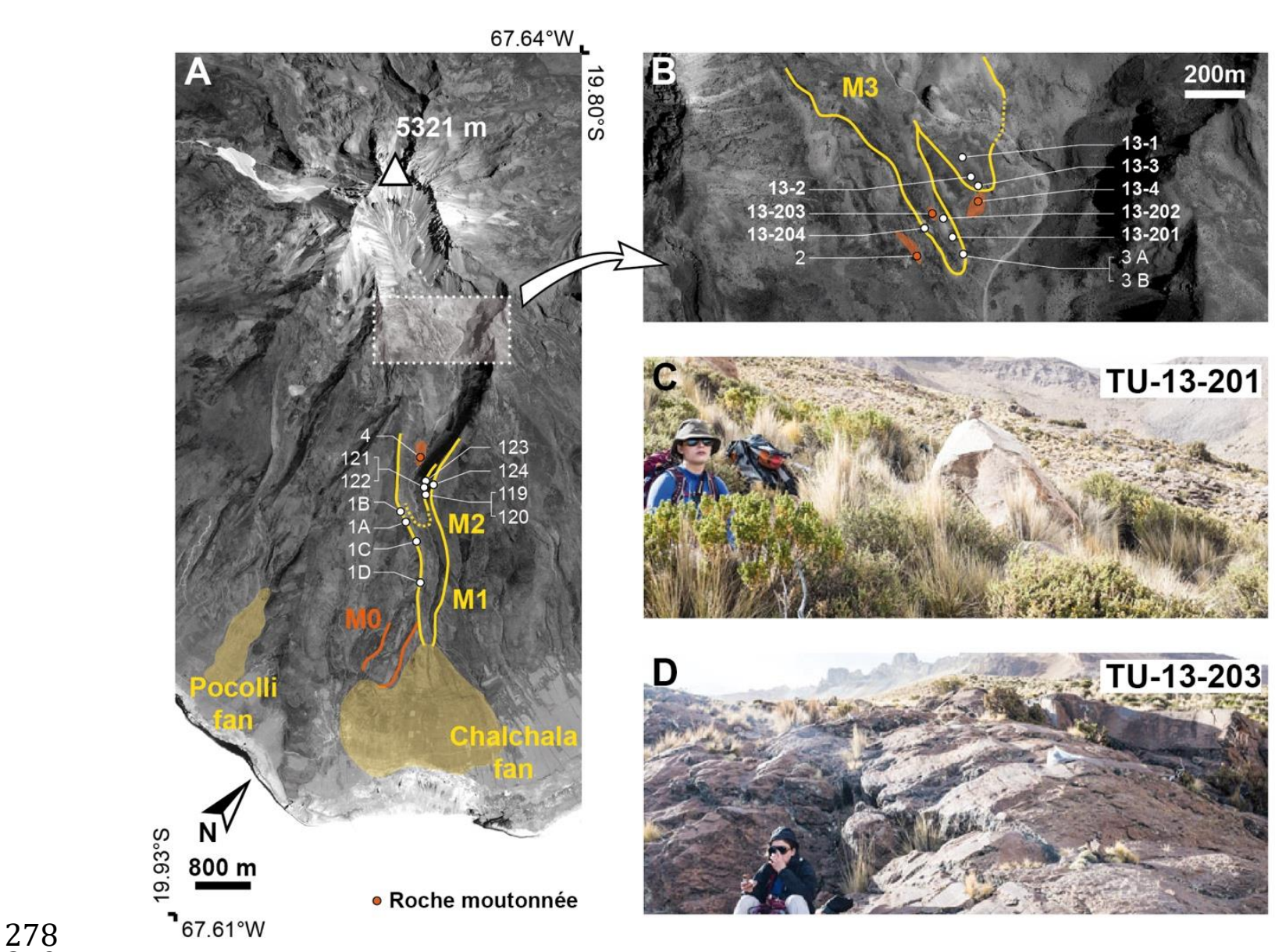

Figure 7. Moraine samples on Cerro Tunupa. (A) Location of the moraines and samples in the main glacial valley. White and orange dots indicate morainic boulder and roches moutonnées samples, respectively. Solid yellow lines delimit the moraines in the main scope of this study. (B) Enlarged view of the upstream samples associated with the M3 morainic complex. (C) The TU-13-201 moraine boulder. (D) The TU-13-203 roche moutonnée. Full sample names include the prefix 'TU-'. Only samples labelled in bold font are from this study (samples including "13-" in (B)); other samples were presented in Blard et al. (2009, 2013a). 
Cerro Luxar is an andesitic stratovolcano in the southwestern Altiplano, $70 \mathrm{~km}$ south of Salar

289 de Uyuni; it belongs to a wide volcanic province extending from the western Cordillera to the center of 290 the Altiplano. Cerro Luxar does not currently have permanent ice cover, but numerous glacial 291 geomorphic features are observed in the valleys carved into its flanks. Because of the andesitic 292 composition of the Luxar volcano, in-situ cosmogenic ${ }^{3} \mathrm{He}$ concentrations in pyroxenes can be used to 293 date the glacial features. The M1 moraine (Fig. 8) is the terminal moraine, corresponding to the last 294 maximal extent of the ice tongue; it is a sharp-crested moraine extending continuously over more than $2951 \mathrm{~km}$ and delimiting a narrow and sinuous ice tongue. The M2 and M3 moraines are recessional 296 moraines located upstream in the valley. M2 extends over $500 \mathrm{~m}$ on the left bank and over $200 \mathrm{~m}$ on the 297 right bank. Martin et al. (2018) measured exposure ages on morainic boulders of moraines M1 and M2 298 (Fig. 8) and dated them at $16.6 \pm 0.7 \mathrm{ka} \mathrm{BP}$ and $15.4 \pm 0.9 \mathrm{ka} \mathrm{BP}$, respectively. Here we extend their 299 results with two samples on boulders of moraine M3 (sampled on the more prominent right bank) and 300 two upper-lying roches moutonnées (located upstream of the three moraines, in the glacial cirque).

301 Combined with the samples of Martin et al. (2018), this glacial landform record spans $1.2 \mathrm{~km}$ 302 horizontally and $450 \mathrm{~m}$ vertically. 


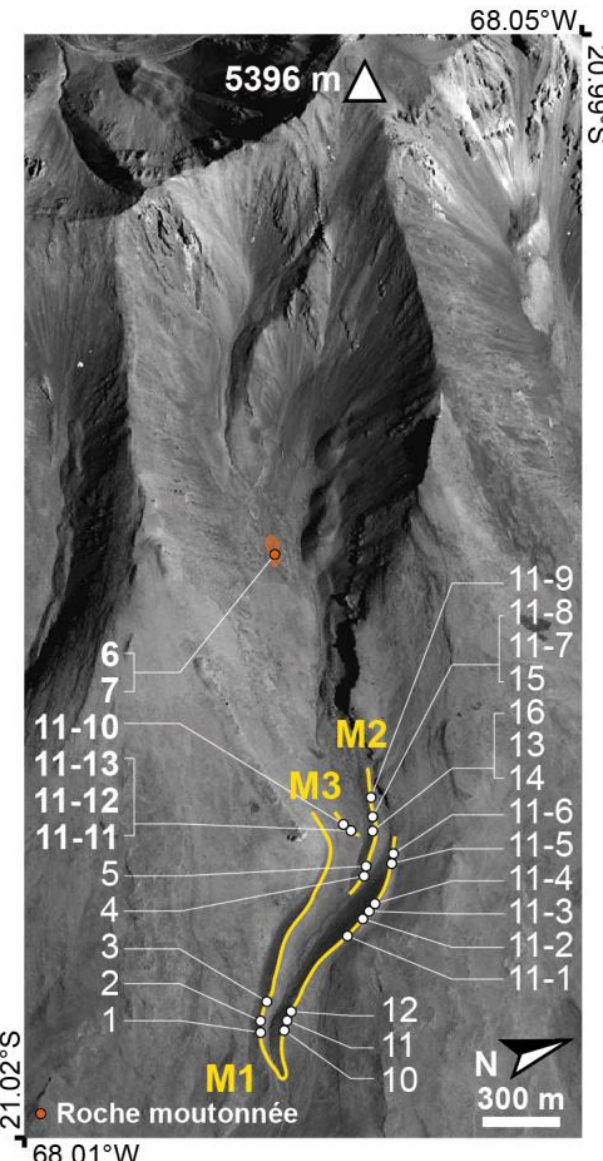

304 Figure 8. Moraine samples on Cerro Luxar detailed on a map of the valley. White and orange dots indicate morainic boulder and roches moutonnées samples, respectively. Solid yellow lines delimit the moraines in the main scope of this study. Full sample names include the prefix 'LUX-'. Only samples labelled in bold font are from this study (M3 and roche moutonnées samples); other samples are from Martin et al. (2018) 


\section{Methods}

\subsection{CRE dating methods}

\subsubsection{Sampling methods}

Boulders were sampled using a hammer and a chisel. We favored large angular boulders to minimize the possibility of recent surface deflation of the diamict matrix. For both boulders and roches moutonnées. the thicknesses of the samples ranged between 2 and $5 \mathrm{~cm}$ (Tables 3-6). The tops of many

315 boulders presented flat or slightly sloping surfaces, generally smooth and clean without any evidence of 316 exfoliation or physical weathering. This suggests that they have experienced only negligible denudation (i.e. less than a few $\mathrm{mm}$ ) since their deposition.

\subsubsection{In-situ ${ }^{10}$ Be concentration measurement}

To measure cosmogenic ${ }^{10} \mathrm{Be}$ concentrations in quartz mineral fractions, samples were prepared at the CRPG (Nancy, France) to obtain pure $\mathrm{BeO}$ targets for subsequent ${ }^{10} \mathrm{Be} /{ }^{9} \mathrm{Be}$ isotopic analysis.

321 Samples were first crushed and wet-sieved to collect the $200-800 \mu \mathrm{m}$ fraction. Quartz grains were 322 magnetically and electrostatically separated, then isolated through selective dissolution in a concentrated $323 \mathrm{H}_{2} \mathrm{SiF}_{6}-\mathrm{HCl}$ solution. Once pure quartz was obtained, $30 \%$ of the mass of each sample was dissolved 324 during three successive HF leaching steps in order to remove any atmospheric ${ }^{10} \mathrm{Be}$ contamination from 325 the quartz. We then added $150-300 \mathrm{mg}$ of an in-house ${ }^{9} \mathrm{Be}$ carrier $\left(2,020 \mathrm{ppm}{ }^{9} \mathrm{Be}\right)$ to the samples and 326 completely dissolved them in concentrated HF. To isolate beryllium, samples were fractionated in three 327 alkaline precipitations alternating with two separations on ionic-exchange columns and a final 328 dehydration at $700{ }^{\circ} \mathrm{C}$.

The resulting $\mathrm{BeO}$ was mixed with niobium powder, introduced into a copper cathode, and pressed. The ${ }^{10} \mathrm{Be} /{ }^{9} \mathrm{Be}$ ratios were analyzed by accelerator mass spectrometry at the French national

331 facility ASTER (LN2C, CEREGE, Aix-en-Provence, France). During each analytical session, the 332 measured ${ }^{10} \mathrm{Be} /{ }^{9} \mathrm{Be}$ ratios were normalized to the ${ }^{10} \mathrm{Be} /{ }^{9} \mathrm{Be}$ ratio of the NIST SRM 4325 reference 333 material $\left({ }^{10} \mathrm{Be} /{ }^{9} \mathrm{Be}=(2.79 \pm 0.03) \times 10^{-11}\right.$; Nishiizumi et al., 2007). During the three analytical sessions, 
334 blank values were $(2.7 \pm 1.7) \times 10^{-15},(1.5 \pm 0.4) \times 10^{-15}$ and $3.9 \times 10^{-15}$, respectively, yielding respective 335 maximum blank corrections of sample ${ }^{10} \mathrm{Be} /{ }^{9} \mathrm{Be}$ ratios of $6 \%, 3 \%$, and $3 \%$.

\subsubsection{In-situ ${ }^{3}$ He concentration measurements}

For cosmogenic ${ }^{3} \mathrm{He}$ measurements, all samples were prepared and analyzed at the CRPG. Samples were crushed and wet-sieved to collect the 180-800 $\mu \mathrm{m}$ fraction. We concentrated heavy minerals by density separation in sodium polytungstate solutions $\left(\mathrm{d} \sim 3.1 \mathrm{~g} \mathrm{~cm}^{-3}\right)$ and rinsed them with deionized water. Black and green pyroxenes were observed and identified by scanning electron microscopy, then mono-mineral grains without any adhering lava were handpicked under a binocular microscope and packed into stain capsules. The prepared pyroxene aliquots weighed between 11.4 and $57.2 \mathrm{mg}$.

The total ${ }^{3} \mathrm{He}$ concentrations of the samples were measured by split flight tube mass spectrometry following a previously established procedure (Blard et al., 2015; Mabry et al., 2012; Zimmermann et al., 2012) summarized here. Pyroxene aliquots were fused in a single vacuum resistance furnace during $15 \mathrm{~min}$ at $1400-1500{ }^{\circ} \mathrm{C}$. The extracted gas was purified using activated carbons, getters, and a cryogenic pump, and ${ }^{3} \mathrm{He}$ and ${ }^{4} \mathrm{He}$ concentrations were analyzed in the spectrometer. Furnace blanks induced a mean correction of $4 \pm 3 \%$ (with a maximal value of $12 \%$ ). The sensitivity of the mass spectrometer was calibrated using the HESJ standard (Matsuda et al., 2002) as described in Blard et al. (2013a) over a range of helium pressures that encompassed those of the measured samples, and from which the adequate sensitivity could be interpolated. Mean $1 \sigma$ external reproducibilities for ${ }^{3} \mathrm{He}$ and ${ }^{4} \mathrm{He}$ of $2.0 \pm 0.6 \%$ and $1.9 \pm 2.3 \%$, respectively, with respective maximum values of $3.1 \%$ and $7.0 \%$. During each analytical session, we measured CRONUS-P pyroxene standard aliquots, which yielded a mean

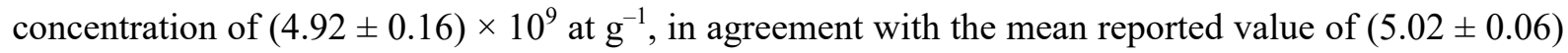
$\times 10^{9}$ at $\mathrm{g}^{-1}$ (Blard et al., 2015).

Blard et al. (2013a, 2014) measured magmatic ${ }^{3} \mathrm{He}$ concentrations in pyroxenes from Cerro Tunupa and Cerro Uturuncu via prolonged vacuum step-crushing. They showed that magmatic ${ }^{3} \mathrm{He}$ concentrations were $2-3$ orders of magnitude below cosmogenic ${ }^{3} \mathrm{He}$ concentrations in volcanic 
360 formations of the Altiplano. Relying on their data, we derived and applied a magmatic ${ }^{3} \mathrm{He}$ correction 361 of $8.50 \times 10^{4}$ at $\mathrm{g}^{-1}$ to all our samples,

362 Nucleogenic ${ }^{3} \mathrm{He}$ concentrations were calculated from the major and trace element compositions 363 of both lavas and phenocrysts, as in Blard et al. (2013a) (measurements performed by SARM-CNRS). 364 We calculated both $(\mathrm{U}-\mathrm{Th}-\mathrm{Sm}) /{ }^{4} \mathrm{He}$ eruption ages and nucleogenic ${ }^{3} \mathrm{He}$ production rates (following 365 Andrews and Kay, 1982 and Andrews, 1985) to derive ${ }^{3} \mathrm{He}$ nucleogenic concentrations. For each 366 sample, the final cosmogenic ${ }^{3} \mathrm{He}$ concentration was obtained by subtracting the magmatic and 367 nucleogenic components from the total ${ }^{3} \mathrm{He}$ concentration. These corrections represent less than $3 \%$ of 368 the total measured ${ }^{3} \mathrm{He}$ concentrations in all samples.

\subsubsection{Cosmogenic exposure age computation}

Because the cosmogenic production rate is a pivotal parameter in the calculation of exposure ages, we relied on the weighted means of local calibration values (detailed below). This approach has two advantages: (i) local calibration values limit potential inaccuracies arising from the spatial scaling procedure (Martin et al., 2015), and (ii) the use of more than one calibration study makes the final calibration value used in the age calculations more robust. The Sea Level High Latitude (SLHL) production rate used to calculate the ${ }^{10} \mathrm{Be} C R E$ ages is the weighted mean of the production rates of Blard et al. (2013a), Kelly et al. (2015), and Martin et al. (2015); these production rates were obtained in the High Tropical Andes from calibration sites within limited distances from the glacial landforms dated in the present study (all are within the Altiplano Basin, except that of Kelly et al., 2015, which is $30 \mathrm{~km}$ away). Similarly, ${ }^{3} \mathrm{He}$ CRE ages were calculated using the weighted mean of the production rates of Blard et al. (2013b, within the basin) and Delunel et al. (2016, $60 \mathrm{~km}$ away). We took the uncertainties of both production rates as the weighted standard deviations (Martin et al., 2017) taken over the individual production rate values and propagated it in the computed ages. CRE computations were performed using the online CREp calculator (Martin et al., 2017) and the modified Lal (1991) time-dependent scaling scheme (Balco et al., 2008; Stone, 2000) with the ERA40 spatialized atmosphere (Uppala et al., 2005) and the virtual dipolar moment (VDM) reconstruction of Muscheler et al. (2005). Borchers et al. (2016) showed that the modified Lal model and the LSD 
model (Lifton et al., 2014) were the most efficient models available to reduce discrepancies between the

388 different calibration studies at SLHL conditions. Martin et al. (2015) similarly showed that the modified

389 Lal scheme performs better in the High Tropical Andes, especially when combined with the ERA-40

390 atmosphere and the VDM reconstruction of Muscheler et al. (2005).

\subsubsection{Bayesian filtering of CRE ages from stratigraphic relationships}

For each moraine in this study, we computed a normalized sum of the probability density

393 function (PDF) of the age of each sample and applied a Bayesian age filtering. Stratigraphic relations

394 between moraines and roches moutonnées bring additional time constraints to the objects that they

395 bracket. These can be formulated in terms of Bayesian conditions (conditional probability) to produce

396 or refine age probability densities associated with moraines (Parnell et al., 2011). We used the approach

397 of Blard et al. (2013b) and Martin et al. (2015) on some of the studied moraines to refine their age

398 distributions and limit the influence of possible outliers on the final results. We consider $f_{\text {object }}$ as the

399 non-filtered initial PDF of the dated object (a function of time $t$ ). Stratigraphic observations enable the

400 identification of an older and a younger object, each associated with its own PDF ( $f_{\text {OlderObject }}$ and

$401 f_{\text {YoungerObject, }}$ respectively). A new filtered PDF $f^{*}$ object can then be recalculated as:

$$
f_{\text {Object }}^{*}(t)=f_{\text {Object }}(t) \times \int_{t}^{\infty} f_{\text {Olderobject }}(\tau) d \tau \times \int_{0}^{t} f_{\text {Youngerobject }}(\tau) d \tau
$$

403 If no measurements are available for the object of interest, or if scatter is too important, a PDF can be 404 derived for the bracketed object by replacing $f_{\text {Object }}$ by 1 .

We systematically used this approach to filter and refine the age distributions of the moraines in this study. For each moraine, a raw PDF was first established as the normalized sum of the PDF of each sample of that moraine. Then, we used Bayesian conditions based on the raw PDFs of older and younger objects to bracket the age to be refined. This was not possible for the oldest and youngest

409 objects at a given site, which only benefited from one Bayesian condition (based on the second oldest 410 or second youngest objects, respectively). This framework was adjusted for special cases exhibiting 411 particularly large scatter among the individual ages associated with the central or bracketing objects. 
412 When the age of the older/younger object was characterized by significant scatter, it was replaced by

413 the object immediately older/younger than itself. When the central object to be refined presented

414 scattered ages older and/or younger than those of the bracketing objects, but the bracketing PDFs were

415 available, we replaced $f_{\text {Object }}$ by 1 . Final moraine ages were determined using the median and $1 \sigma$-range

416 of the thusly-refined moraine PDFs. For simplicity, the uncertainty associated with each moraine age is

417 the mean of the left and right $1 \sigma$ distances to the median. Illustration of the Bayesian processing on age

418 data is illustrated on Fig. S6 (Supplementary Information).

\subsection{Equilibrium line altitude calculation methods}

At the equilibrium line altitude (ELA) of a glacier, the glacier's mean annual mass balance is

null. Because ELA is an integrative signal of the climatic conditions driving glacial dynamics (Ohmura

et al., 1992), paleo-ELAs have been extensively used over the past 40 years for climate reconstructions

(Loibl et al., 2014; Porter, 2000; Sissons and Sutherland, 1976; Stauch and Lehmkuhl, 2010). Several

methods have been reported and compared to infer paleo-ELAs from the geomorphic features of glacial

valleys (Benn et al., 2005; Benn and Lehmkuhl, 2000; Meierding, 1982). These methods rely on

different observations, such as the glacial cirque altitude, the maximum elevation of lateral moraines,

the terminus altitude, or the hypsometry of the valley, and require variable amounts of knowledge about

past glacial extents. Here we used the accumulation area ratio (AAR) method, which enables ELA determination for several glacial standstills in the same valley. This method does not require any balance ratio or index, and is thus less precise than the balance ratio or area altitude balance ratio methods

431 (Osmaston, 2005). However, because the AAR method accounts for the surfaces of the ablation and 432 accumulation zones, it is a more explicit reference to the surface glacier mass balance than the widely 433 used toe-to-summit and toe-to-headwall altitude ratios (Benn and Lehmkuhl, 2000; Osmaston, 2005).

434 The AAR method has been applied to derive accurate ELA values in various mountain glacier settings (e.g. Martin et al., 2018).

ELA determinations using the AAR method rely on the use of an appropriate AAR parameter,

437 which ranges between 0.5 and 0.8 for present glaciers around the world (see Benn and Lehmkuhl, 2000,

438 and Benn et al., 2005, for reviews). Here, we used AAR values based on mass balance measurements 
conducted on three Andean glaciers by the GLACIOCLIM-IRD National Observation Service (Rabatel

et al., 2013; Soruco et al., 2009). Observed present-day AAR values were regressed against annual mass

441 balance measurements to account for the non-equilibrium conditions that characterize most 442 glaciological years over the last three decades in the Andes. We established AAR values for this study 443 as the $y$-intercepts of these regressions (i.e. the AAR for a null mass balance, see supplementary material 444 of Martin et al., 2018, for details). Thus, we used an AAR range of 0.63-0.73 (average 0.68), consistent 445 with Martin et al. (2018), to account for uncertainties (see review of AAR variability in Benn and 446 Lehmkuhl, 2000). Required hypsometry data were derived from the NASA-USGS SRTM 1-arcsecond 447 global digital elevation model (DEM).

\subsection{Climatic inversion methods}

\subsubsection{Glacial extent and climatic conditions}

Climate controls glacial dynamics through accumulation (snowfall) and ablation (mainly melting and sublimation). Glaciers, and, more precisely, the past glacial extent indicated by moraine records, have thus been used as proxies of past climatic changes. Sagredo and Lowell (2012) proposed a complete climatic setting for Andean glaciers. They proposed classifying glaciers into different groups

454 characterized by common climate settings. The glacial records presented in this study span two groups, 455 the Cordillera Real and the southeast Altiplano, both characterized by cold and homogenous 456 temperatures throughout the year and low precipitation inputs during the Austral summer (see Section 457 1). The main difference between these two groups is annual rainfall, with the Cordillera Real receiving more precipitation than the southeast Altiplano (700 vs. $300 \mathrm{~mm} \mathrm{yr}^{-1}$ ). In the southern Altiplano, 459 although their summits stand above the $0{ }^{\circ} \mathrm{C}$ isotherm during the ablation season, volcanoes such as 460 Cerro Tunupa (5,321 $\mathrm{m}$ asl) and Cerro Luxar (5,396 $\mathrm{m}$ asl) do not presently have permanent ice cover 461 due to the low annual precipitation. This primary dependence of glacial dynamics on precipitation makes 462 the region precipitation-limited (Ammann et al., 2001; Kull et al., 2008). Considering the characteristic response time of several decades for mountain glaciers (Leclercq 464 et al., 2014), we consider them to be in equilibrium with climatic conditions for our reconstructions. 465 Therefore, we followed Martin et al. (2018, methodological comparison and discussion provided in their 
466 Supplementary Information) and used empirical relations between ELA and the present climate derived

467 from statistical analyses of modern glaciers. These relations consider that the ELA position depends

468 primarily on mean temperature and precipitation values; enhanced accumulation concomitant with

469 lowering of the ELA is associated with decreased temperature and/or increased precipitation, whereas

470 the opposite trend is associated with raising of the ELA (Condom et al., 2007; Kuhn, 1989; Ohmura et

471 al., 1992; Seltzer, 1994). For the Central Andes, Condom et al. (2007) extended the work of Fox (1993)

472 to derive ELA (m asl) as:

$$
E L A=3427-1148 \times \log _{10}(P)+\frac{T(z)}{L R}+z
$$

474 where $P$ is the annual rainfall $(\mathrm{mm}), T$ is mean annual temperature $\left({ }^{\circ} \mathrm{C}\right), L R$ is the atmospheric lapse rate

$475\left({ }^{\circ} \mathrm{C} \mathrm{m}^{-1}\right)$, and $z$ is the altitude of the temperature measurement ( $\mathrm{m}$ asl). As in Martin et al. (2018), we 476 chose this modeling approach for several reasons: (i) Equation (2) directly links ELA to the investigated 477 climatic variables; (ii) it is easy to use in terms of data availability, calculation, and error propagation; 478 (iii) contrary to energy balance models, it requires limited atmospheric variables; and (iv) it performs 479 well for Bolivian glaciers (see Fig. S13 in Martin et al., 2018).

\subsubsection{Present-day temperature and precipitation at the glacial sites}

To document paleoclimatic variations, we consider the present as a reference state. We used homogenized monthly weather station data (Vuille et al., 2008; Martin et al., 2018) to establish the reference climatic conditions at the four studied paleoglacial sites (Table 1). This record includes 57 temperature stations and 102 precipitation stations spanning $14-23^{\circ} \mathrm{S}$ (including the cordilleras and the Altiplano) over the observational periods 1948-2001 (precipitation) and 1948-2007 (temperature). The

486 derived mean temperature and annual precipitation values for the four paleoglacial sites studied herein are reported in Table 1. 
Sites

Latitude ( $\left.{ }^{\circ} \mathrm{S}\right)$

Longitude $\left({ }^{\circ} \mathrm{W}\right)$

Summit elevation (masl)

Mean annual

Rainfall (mm)

Mean annual temperature normalized to 3800 masl ${ }^{a}\left({ }^{\circ} \mathrm{C}\right)$

Zongo

Sajama

Tunupa

Luxar

$\begin{array}{rrrr}16.2 & 18.1 & 19.8 & 21.0 \\ 68.1 & 68.9 & 67.6 & 68.0 \\ 6088 & 6542 & 5321 & 5440 \\ & & & \\ 529 \pm 9 & 329 \pm 7 & 201 \pm 15 & 136 \pm 16 \\ 8.5 \pm 0.2 & 7.7 \pm 0.6 & 6.3 \pm 0.2 & 7.5 \pm 0.7\end{array}$

${ }^{a}$ Normalization calculated for a lapse rate of $6.5^{\circ} \mathrm{C} / \mathrm{km}$

Table 1. Present annual rainfall and mean temperature at the studied sites derived from weather station measurements (Vuille et al., 2008; Martin et al., 2018). Observation from 1948 to 2001 for precipitation and 1948 to 2007 for temperature. Temperatures normalized at 3800 masl for comparison purpose.

Equation (2) implies that a given ELA could correspond to several local precipitationtemperature pairs. Therefore, additional constraints are required to derive unique precipitation and temperature pairs for each ELA. To do so, we couple glacier and lake modeling following Blard et al. (2009), Placzek et al. (2013) and Martin et al. (2018), but we extend their approach to the entire deglaciation, between 18 and $10 \mathrm{ka} \mathrm{BP.}$

\subsubsection{Lake model}

We used the lake model of Condom et al. (2004) as modified by Martin et al. (2018). This model divides the Altiplano Basin into lake and soil pixels. All soil pixels are considered to be a reservoir that can be filled until its overflow threshold (CapaS) is reached. When precipitation fills the reservoir above CapaS, water flows directly to the lake. The flow path of water from the watershed pixel to the lake is not taken into account. As in Blard et al. (2009), the equation used to calculate evaporation is derived from the generalized equation of Xu and Singh (2000) that relies on a simplified energy balance budget. The model is run at a quarterly time resolution and a $5-\mathrm{km}$ spatial resolution. Because gridded products are necessary for the lake model, the temperature and precipitation inputs are derived from the dataset of New et al. (2002). Elevation is based on the 1-arcsecond SRTM DEM. The CapaS value was calibrated from the Titicaca watershed for the present period. The modifications of Martin et al. (2018) to the original model of Condom et al. (2004) account for the potential yearly accumulation of seasonal snow stock on watershed pixels. The distributed model computes the melting of this stock using a 
511 positive degree day (PDD) value of $6 \mathrm{~mm}^{\circ} \mathrm{C}^{-1} \mathrm{~d}^{-1}$. Melted snow first fills the soil reservoir until reaching

512 CapaS and overflowing. Further details are available in the Supplementary Information of Martin et al.

513 (2018).

\subsubsection{Coupled lake and glacier modeling}

515

The complete inversion workflow is presented in Fig. 9 and operates as follows. For a given

516 late-glacial moraine of a paleoglacier, we have access to its age via CRE dating and its ELA via the

517 AAR method. From this ELA, the relation of Condom et al. (2007) provides a set of local $P$ - $T$ solutions

518 that respect the glacial extent (green path in Fig. 9). From the moraine age, the algorithm considers the

519 synchronous lake shoreline in the updated dataset of the lake level chronology (see Section 4.1.1). The

520 paleolake extent corresponding to the selected level is then used to compute the correct hydrologic

521 balance for different cooling and precipitation values (blue path in Fig. 9). The precipitation field used

522 in the model includes a local anomaly of enhanced rainfall over the lake region (see Section 3.3.5 and

523 Supplementary Information). The intersection of these two computed $P-T$ curves (sets of solutions) then

524 defines the precise climatic conditions (i.e. a single $P$ - $T$ pair) associated with the glacial extent. We note

525 that, despite major lake-size variations, both the continuous sediment accumulation in the Coipasa Basin

526 throughout the study period (Nunnery et al., 2019) and the presence of shoreline records indicate that

527 the lake did not completely dry prior to the Holocene; this algorithm is therefore applicable to the entire

528 last deglaciation. 


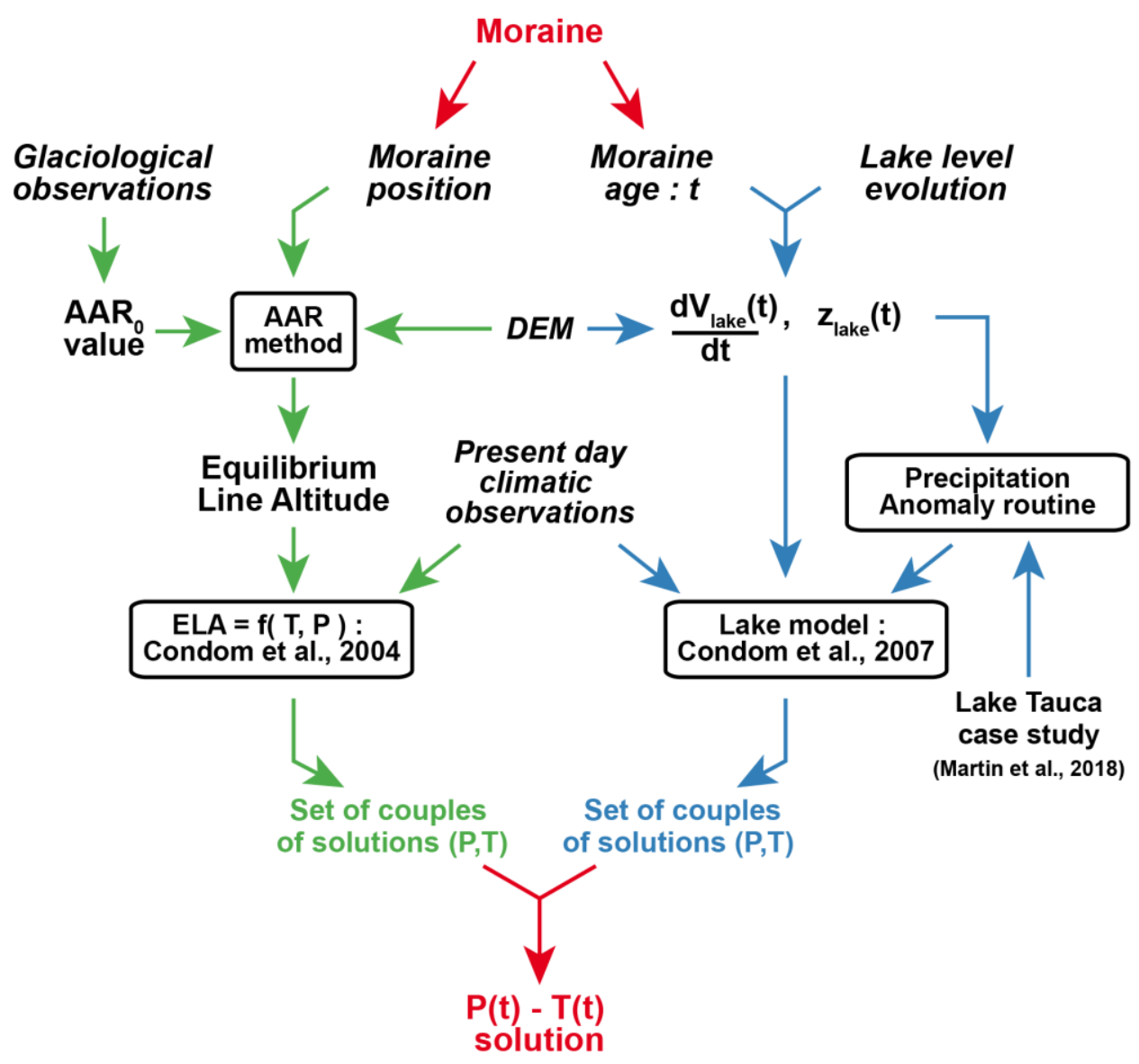

solution

Figure 9. Workflow for paleoclimatic inversions in this study. Lake level evolutions are based on 531 Sylvestre et al. (1999), Placzek et al. (2006), and Blard et al. (2011a), and include the updated Coipasa highstand of the present study (see Section 2.2 and 4.1.1). Glaciological observations are from Soruco et al. (2009) and Rabatel et al. (2013). Moraine ages are either original ages from this study or ages from the literature (see Section 2.3). Present day climatic observations are from New et al. (2002) for gridded products (lake model inputs) and station data (Vuille et al., 2008) for site-specific data $(E L A(P, T)$ inputs). We used the NASA-USGS SRTM 1-arcsecond DEM. Details on the Precipitation Anomaly routine are provided in Section 3.3.5. Input data are italicized. 
Martin et al. (2018) recently established the spatial distribution of precipitation during the Tauca

540 Highstand, which evidences the local recycling of lake water superimposed on the global rainfall field.

541 Here, we develop a novel algorithm to account for this lake-induced local precipitation anomaly. In 542 practice, this routine uses the case study of Martin et al. (2018) to mimic the Lake Tauca rainfall anomaly

543 for any given lake geometry and extent. This routine is necessary because they showed this recycling 544 effect to have a non-negligible impact on the spatial distribution of rainfall. Moreover, the four studied 545 glacial sites are contrastingly impacted by this regional precipitation anomaly: whereas Zongo Valley is 546 far from any paleolake influence, the Tunupa and Luxar glaciers, being close to the paleolake centers, 547 were highly impacted by this recycling. To define the geometry of this regional rainfall recycling, we 548 chose an empirical approach that aims to adapt the radial evolution of the Tauca anomaly for any lake 549 configuration of the last deglaciation. In this simplified framework, we define the paleoprecipitation 550 grid as:

$$
P(x, y, t)=P_{\text {Present }}(x, y) \times \alpha(t) \times\{1+\beta(\text { lake }(t)) \times A(x, y, \text { lake }(t))\}
$$

where $P$ is the precipitation field over the basin (two spatial dimensions $x$ and $y$ ) at a given time $t$ of the 553 last deglaciation, $P_{\text {Present }}$ is the present day precipitation field over the basin, $\alpha$ is a scalar regional 554 amplification factor, $\beta$ is the amplitude of the recycling anomaly based on the lake surface, and $A$ is the 555 normalized anomaly grid. $\beta$ is empirically calibrated using hydrological data from several intertropical 556 lakes (Lakes Mweru, Malawi, Titicaca, and Victoria; see Supplementary Information S4). We obtained 557 a relation fitting $\beta$ to the lake surface $\left(S_{\text {lake, }}, \mathrm{km}^{2}\right)$ with a coefficient of determination $\left(R^{2}\right)$ of 0.97 .

$$
\beta=0.27 \times \ln \left(S_{\text {lake }}\right)-2.10
$$

We then used the Tauca highstand case study of Martin et al. (2018) to establish the matrix $A(x$, $560 y, t=$ Tauca highstand $)=A_{\text {Tauca }}$ and thus isolate the recycling anomaly. To do so, we inverted Equation 561 (3) for $t=$ Tauca highstand. The value of $\alpha_{\text {Tauca }}$ was taken as 2.4 , the mean $P_{\text {Tauca }} / P_{\text {Present }}$ ratio for Zongo 562 Valley and Nevado Sajama, which corresponds to the increased precipitation far from the Tauca paleolake influence. Then, $\beta_{\text {Tauca }}$ was computed using Equation (4). 
To adapt the shape of the recycling anomaly to the different lacustrine configurations of the last

565 deglaciation, we first approached the Tauca anomaly as follows. We first computed the barycenter of

566 Lake Tauca, which we defined as the point of the lake surface for which the sum of the distances to all

567 other points on the lake surface is minimal. From this barycenter, we discretized the Altiplano Basin

568 into 20 regular angular sectors ("pie slices"). The mean radius of the lake for a given sector was

569 computed considering the mean distance from the barycenter to all Lake Tauca points within that sector.

570 Then, the radially decreasing anomaly profile (from the barycenter towards the watershed edges) was

571 averaged per sector and normalized by the mean lake radius of each sector.

$572 \quad$ For the different lake configurations during deglaciation, we then assumed that the recycling

573 anomaly can be deduced from the Tauca anomaly by some kind of homothety (a transformation

574 preserving angles and length ratios) centered on the paleo-barycenter of the lake. We therefore implicitly

575 assume that the redistribution of the local lake-evaporation moisture is primarily driven by the

576 geographic extent of the water body, and that the wind regime has not drastically changed. For each

577 paleo-lake extension, we then calculated its barycenter, the angular sectors, and the mean lake radius

578 per sector, and applied the normalized radial profile (defined by the Lake Tauca extent) to derive $A(x$, $579 y, t)$.

$580 \quad$ Once $A(x, y, t)$ was established, $\beta(t)$ was calculated using Equation (4) and $\alpha(t)$ was numerically 581 adjusted so that the climatic input to the lake model is in accordance with the prescribed lake budget 582 (Fig. 9). The reconstructed anomaly fields (given as $\beta \times A$ ) for the Lake Coipasa and Lake Tauca 583 highstands are shown in Figure 10. Further details of the anomaly algorithm are provided in the 584 Supplementary Information (and graphically illustrated in Fig. S3). The resulting precipitation field is 585 in excellent agreement with the ELA-derived precipitation map of Martin et al. (2018; see their Fig. 586 3D). 

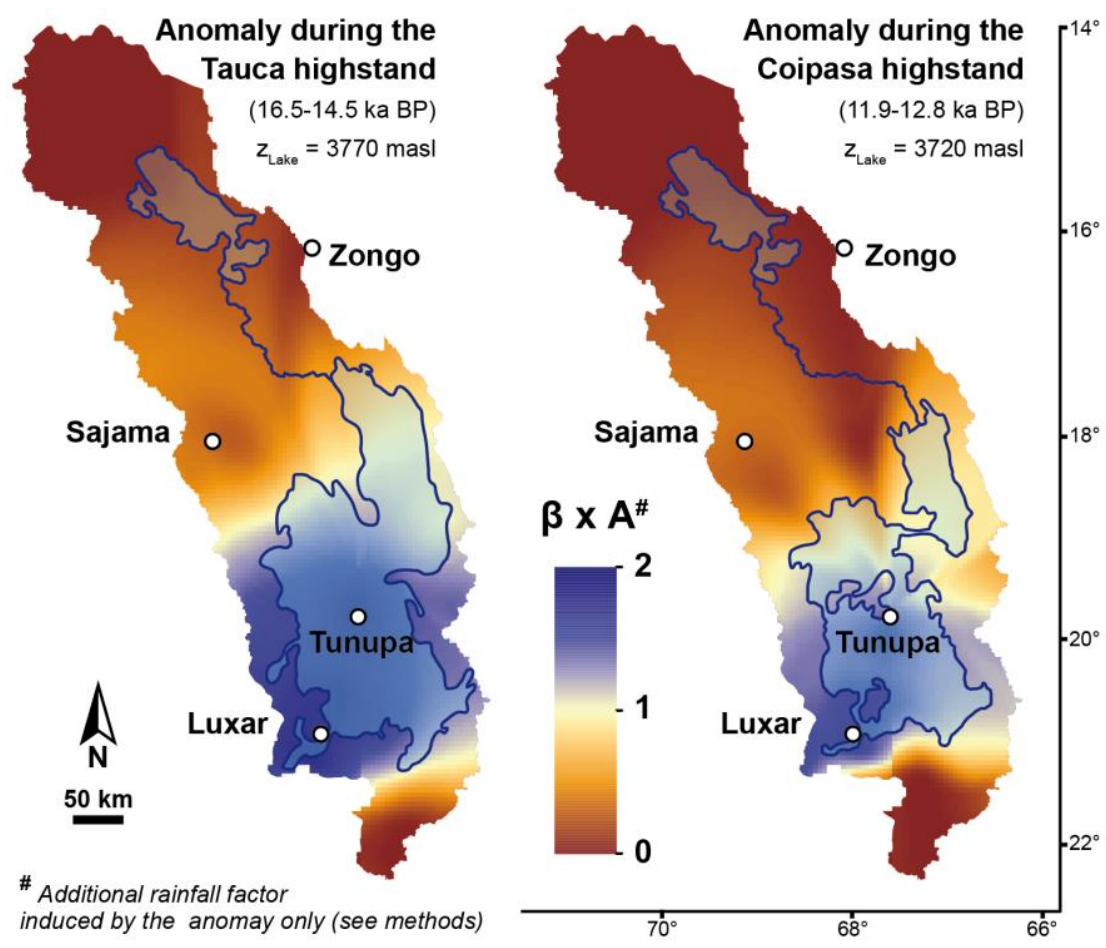

588 Figure 10. Reconstructed precipitation anomaly fields of the Tauca and Coipasa highstands using the 589 anomaly algorithm (see Section 3.3.5 and Supp. Info. S2) compared to the present. Reported values are 590 the product $\beta \times A$. 


\section{Results}

\subsection{Dating results}

Our new ${ }^{14} \mathrm{C}$ ages (Table 2) and all previously published radiocarbon ages were calibrated relative to 2010 using OxCal 4.2 (Ramsey, 2009) and the IntCal13 calibration curve (Reimer, 2013).

597 This updated dataset was used to refine our knowledge of the evolution of the lake level through time

598 (Fig. 11). Our four new calibrated ages span the Tauca and Coipasa lake cycles, with sample INC-13-2 599 (15.97 $\pm 0.11 \mathrm{cal}$ kyr BP) belonging to the transgressive or deep part of the Lake Tauca cycle. Both 600 replicates of INC-13-3 (INC-13-3A and INC-13-3B) yield ages of $12.75 \pm 0.03$ and $12.09 \pm 0.13 \mathrm{cal} \mathrm{kyr}$ 601 BP, respectively, precisely coeval with the Lake Coipasa highstand. However, sample INC-13-1 does 602 not fit the lake level curve established by Blard et al. (2011a); its age of $13.44 \pm 0.05$ cal kyr BP is $1 \mathrm{kyr}$ 603 too young to belong to the Tauca highstand and 1 kyr too old for the Coipasa highstand. This single 604 sample is at odds with the complete dataset, which supports the near-complete evaporation of the lake 605 between 14 and 13 ka BP (see summary in Blard et al., 2011a). Thus, we consider sample INC-13-1 to 606 be partially contaminated by modern or dead carbon and exclude it from further discussion.

\begin{tabular}{|c|c|c|c|c|c|c|c|c|c|}
\hline Sample & Material & $\begin{array}{l}\text { Latitude } \\
\operatorname{Dec}^{\circ}\end{array}$ & $\begin{array}{l}\text { Longitude } \\
\mathrm{Dec}^{\circ}\end{array}$ & $\begin{array}{c}\text { Elevation } \\
\text { masl }\end{array}$ & $\begin{array}{c}\text { Mass } \\
m g\end{array}$ & $\begin{array}{c}\delta^{13} \mathrm{C} \\
\% \text { vs } P D B\end{array}$ & $\begin{array}{c}\text { Modern C } \\
\% \\
\end{array}$ & $\begin{array}{c}{ }^{14} \mathrm{Cage}^{\mathrm{a}} \\
y r \\
\end{array}$ & $\begin{array}{c}\text { Calendar age }(1 \sigma)^{\mathrm{b}} \\
k a \mathrm{BP} \\
\end{array}$ \\
\hline INC-13-1 & $\begin{array}{c}\text { Bioherm, white massive } \\
\text { algal carbonate } \\
\text { (external part) }\end{array}$ & $-20,2435$ & -676255 & 3715 & 0.35 & 2.28 & $23.8 \pm 0.2$ & $11550 \pm 50$ & $13.44 \pm 0.05$ \\
\hline INC-13-2 & $\begin{array}{c}\text { Bioherm, cream-coloured } \\
\text { carbonate } \\
\text { (internal part) }\end{array}$ & -20.2433 & 3023.023 & (3) & 0.37 & 1.53 & $19.2 \pm 0.2$ & $13240 \pm 60$ & $15.97 \pm 0.11$ \\
\hline $\begin{array}{l}\text { INC-13-3-A } \\
\text { INC-13-3-B }\end{array}$ & $\begin{array}{l}\text { Bioherm, white massive } \\
\text { algal carbonate }\end{array}$ & -20.2432 & -67.6254 & 3720 & $\begin{array}{l}0.62 \\
0.69\end{array}$ & 2.65 & $26.2 \pm 0.1$ & $\begin{array}{l}10745 \pm 45 \\
10270 \pm 45\end{array}$ & $12.75 \pm 0.03$ \\
\hline
\end{tabular}

608 Table 2. Radiocarbon results for lacustrine bioherms of Incahuasi Island. 


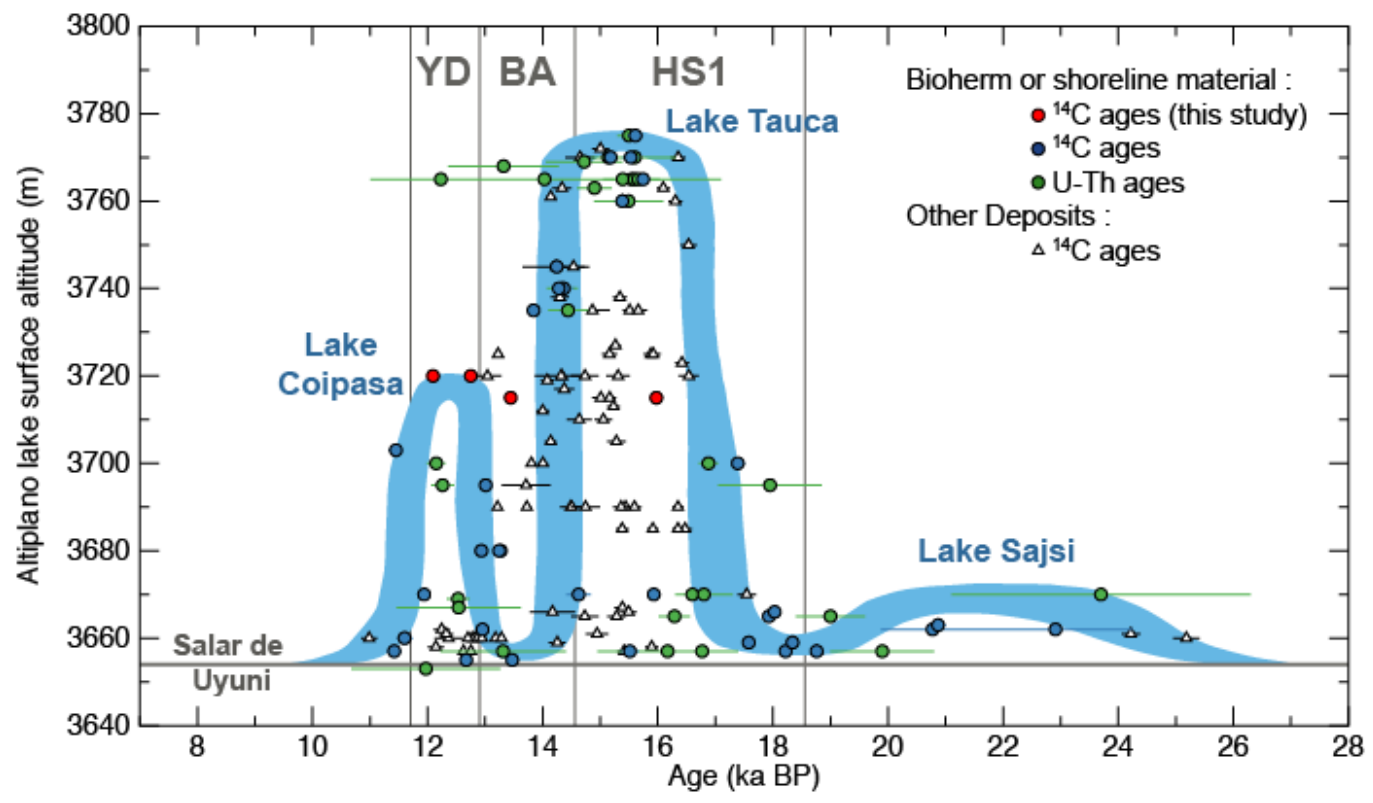

Figure 11. Paleolake chronology of the southern Altiplano. The blue curve is updated from Blard et al., (2011a) to fit a Lake Coipasa highstand 15-20 m above their values, as indicated by our new data (red points). Other data (blue, green, and white points) are from Blard et al. (2011a), Placzek et al. (2006), and Sylvestre et al. (1999).

The most important update from this new dataset is that the two ${ }^{14} \mathrm{C}$ ages of bioherms INC-133A and B belong to the Lake Coipasa (Younger Dryas) event (Fig. 11). These samples stand at 3,720 m asl, indicating that the Coipasa highstand was probably 15-20 m higher than previously reported (Blard et al., 2011a; Placzek et al., 2006) (Table 2; Fig. 11). This additional lake volume will induce a different hydrological balance for Lake Coipasa compared with previous studies.

\subsection{2. ${ }^{10}$ Be moraine chronology of Zongo Valley}

The CRE age results from Zongo Valley are presented in Table 3 and Figure 12. Moraines IP1 and IP2 (from Smith et al., 2005) exhibit extreme scatter; although it is hard to identify their precise timing in the late-glacial period, their position in the valley necessitates that they are older than the other moraines. Therefore, they are probably older than IP3 and have an age of at least $17 \mathrm{ka} \mathrm{BP}$. The three IP3 ages of Martin et al. (2018) are consistent with the four from Smith et al. (2005). By imposing the Bayesian condition that IP4 is a younger object, the age distribution of IP3 is narrowed by a few centuries towards older ages, yielding a final age of $16.9 \pm 0.8 \mathrm{ka}$ BP. Sample MB4 from moraine IP4 has an age two times older than those of two other samples from the same moraine that cluster well 
630 (36.9 ka BP compared to $16.6 \mathrm{ka} \mathrm{BP}$ ). This outlier was filtered out by our Bayesian processing when 631 using IP3 as an older object, giving a final age of $16.0 \pm 0.8 \mathrm{ka}$ BP for moraine IP4. The exposure ages 632 of samples from moraines IP5, CQ1, CQ3, and CQ4 cluster well and form a unique age peak in the PDF. 633 Our Bayesian processing has only a marginal effect on these ages, which yield respective average values 634 of $13.6 \pm 0.8,11.6 \pm 0.5,10.7 \pm 0.4$, and $10.1 \pm 0.4 \mathrm{ka} \mathrm{BP}$. Due to its upper position and its being 635 disconnected from the other glacier systems, we could not refine the ages for moraine IP $\alpha$ via Bayesian 636 filtering and its age PDF is bimodal; the main peak yields an age of $14.9 \pm 0.9 \mathrm{ka} \mathrm{BP}$.

637 With CRE ages ranging from 9 to $21 \mathrm{ka} \mathrm{BP,} \mathrm{moraine} \mathrm{MV} \mathrm{exhibits} \mathrm{substantial} \mathrm{scatter.} \mathrm{However,}$ 638 imposing the Bayesian conditions that IP5 and CQ1 are older and younger than MV, respectively, 639 narrows its age distribution to $12.6 \pm 0.8 \mathrm{ka}$ BP. Bayesian filtering also substantially modifies the PDF 640 of moraine T1, yielding an age of $12.4 \pm 1.5 \mathrm{ka} \mathrm{BP}$. Bayesian modifications are more marginal for T2 641 and T3, yielding respective ages of $11.0 \pm 0.8$ and $9.8 \pm 0.9 \mathrm{ka} \mathrm{BP}$. 


\begin{tabular}{|c|c|c|c|c|c|c|c|c|c|c|c|}
\hline Moraine & Source & Sample & $\begin{array}{l}\text { Latitude } \\
\text { Dec }^{\circ}\end{array}$ & $\begin{array}{l}\text { Longitude } \\
\text { Dec }^{\circ}\end{array}$ & $\begin{array}{c}\text { Altitude } \\
\text { masl }\end{array}$ & $\begin{array}{c}{ }^{10} \mathrm{Be}(\mathbf{1} \sigma) \\
10^{5} \text { at. } g^{-1} \\
\end{array}$ & $\begin{array}{c}\text { Thickness } \\
\mathrm{cm}\end{array}$ & $\begin{array}{c}\text { Thick. Corr. } \\
. \\
\end{array}$ & $\begin{array}{c}\text { Shielding }^{\mathrm{b}} \\
- \\
\end{array}$ & $\begin{array}{c}\text { Scaling Factor } \\
- \\
\end{array}$ & $\begin{array}{c}\text { Age }(1 \sigma)^{\mathrm{d}} \\
k a \\
\end{array}$ \\
\hline \multirow{7}{*}{ IP1 } & \multirow{7}{*}{ Smith et al., 2005} & ZONG-03-06 & -16.1310 & -68.1697 & 3417 & $3.57 \pm 0.14$ & 1 & 0.99 & 0.87 & 6.1 & $16.8 \pm 0.7$ \\
\hline & & ZONG-03-07 & -16.1314 & -68.1697 & 3408 & $3.47 \pm 0.15$ & 4 & 0.97 & 0.89 & 6.0 & $16.5 \pm 0.7$ \\
\hline & & ZONG-03-08 & -16.1310 & -68.1693 & 3399 & $1.15 \pm 0.05$ & 3 & 0.98 & 0.85 & 5.4 & $6.3 \pm 0.3$ \\
\hline & & ZONG-03-09 & -16.1310 & -68.1693 & 3393 & $3.33 \pm 0.09$ & 3 & 0.98 & 0.89 & 6.0 & $15.9 \pm 0.5$ \\
\hline & & ZONG-03-10 & -16.1309 & -68.1692 & 3391 & $1.31 \pm 0.05$ & 3 & 0.98 & 0.89 & 5.5 & $6.8 \pm 0.3$ \\
\hline & & ZONG-03-11 & -16.1310 & -68.1691 & 3383 & $0.69 \pm 0.04$ & 3 & 0.98 & 0.89 & 5.2 & $3.8 \pm 0.3$ \\
\hline & & ZONG-03-12 & -16.1309 & -68.1692 & 3386 & $2.51 \pm 0.07$ & 2 & 0.98 & 0.89 & 5.8 & $12.2 \pm 0.5$ \\
\hline \multirow{5}{*}{ IP2 } & \multirow{5}{*}{ Smith et al., 2005} & ZONG-03-01 & -16.1366 & -68.1755 & 3489 & $4.73 \pm 0.24$ & 1 & 0.99 & 0.95 & 6.5 & $19.2 \pm 0.9$ \\
\hline & & ZONG-03-02 & -16.1366 & -68.1755 & 3500 & $4.15 \pm 0.12$ & 3 & 0.98 & 0.95 & 6.4 & $17.4 \pm 0.6$ \\
\hline & & ZONG-03-03 & -16.1367 & -68.1757 & 3503 & $3.27 \pm 0.12$ & 2 & 0.98 & 0.95 & 6.2 & $14.0 \pm 0.6$ \\
\hline & & ZONG-03-04 & -16.1367 & -68.1757 & 3503 & $1.97 \pm 0.09$ & 1 & 0.99 & 0.95 & 6.0 & $8.7 \pm 0.4$ \\
\hline & & ZONG-03-05 & -16.1368 & -68.1757 & 3505 & $3.54 \pm 0.14$ & 1 & 0.99 & 0.95 & 6.2 & $14.9 \pm 0.6$ \\
\hline \multirow{7}{*}{ IP3 } & \multirow{3}{*}{ Martin et al., 2018} & MB6 & -16.1915 & -68.1330 & 3870 & $5.02 \pm 0.19$ & 1 & 0.99 & 0.97 & 7.7 & $16.8 \pm 0.7$ \\
\hline & & MB7 & -16.1918 & -68.1326 & 3886 & $5.02 \pm 0.16$ & 1 & 0.99 & 0.97 & 7.7 & $16.7 \pm 0.6$ \\
\hline & & MB8 & -16.1918 & -68.1325 & 3887 & $4.69 \pm 0.25$ & 3 & 0.98 & 0.97 & 7.7 & $15.9 \pm 0.8$ \\
\hline & \multirow{4}{*}{ Smith et al., 2005} & ZONG-00-06 & -16.1333 & -68.1919 & 3895 & $4.76 \pm 0.21$ & 5 & 0.96 & 0.98 & 7.7 & $16.2 \pm 0.7$ \\
\hline & & ZONG-00-07 & -16.1333 & -68.1919 & 3895 & $5.14 \pm 0.21$ & 5 & 0.96 & 0.95 & 7.8 & $17.7 \pm 0.7$ \\
\hline & & ZONG-00-08 & -16.1333 & -68.1919 & 3895 & $4.71 \pm 0.16$ & 5 & 0.96 & 0.98 & 7.7 & $16.0 \pm 0.6$ \\
\hline & & ZONG-00-09 & -16.1333 & -68.1919 & 3895 & $4.30 \pm 0.15$ & 5 & 0.96 & 0.98 & 7.6 & $14.9 \pm 0.5$ \\
\hline \multirow{3}{*}{ IP4 } & \multirow{3}{*}{ Martin et al., 2018} & MB1 & -16.1932 & -68.1328 & 3768 & $4.65 \pm 0.42$ & 2 & 0.98 & 0.97 & 7.3 & $16.6 \pm 1.3$ \\
\hline & & MB2 & -16.1933 & -68.1320 & 3784 & $4.66 \pm 0.22$ & 2 & 0.98 & 0.96 & 7.3 & $16.6 \pm 0.8$ \\
\hline & & MB4 & -16.1933 & -68.1317 & 3790 & $11.05 \pm 0.92$ & 0.5 & 1.00 & 0.96 & 7.7 & $36.9 \pm 2.8$ \\
\hline \multirow{5}{*}{ IP5 } & \multirow{5}{*}{ Smith et al., 2005} & ZONG-00-01 & -16.1308 & -68.1962 & 3806 & $3.56 \pm 0.18$ & 5 & 0.96 & 0.95 & 7.2 & $13.5 \pm 0.7$ \\
\hline & & ZONG-00-02 & -16.1308 & -68.1962 & 3806 & $3.75 \pm 0.22$ & 5 & 0.96 & 0.95 & 7.2 & $14.1 \pm 0.8$ \\
\hline & & ZONG-00-03 & -16.1308 & -68.1962 & 3806 & $3.33 \pm 0.23$ & 5 & 0.96 & 0.95 & 7.2 & $12.6 \pm 0.9$ \\
\hline & & ZONG-00-04 & -16.1308 & -68.1962 & 3806 & $3.57 \pm 0.16$ & 5 & 0.96 & 0.95 & 7.2 & $13.5 \pm 0.7$ \\
\hline & & ZONG-00-05 & -16.1308 & -68.1962 & 3806 & $3.71 \pm 0.14$ & 5 & 0.96 & 0.95 & 7.2 & $14.0 \pm 0.6$ \\
\hline \multirow{10}{*}{ MV } & \multirow{10}{*}{ This Study } & MB9 & -16.2321 & -68.1179 & 4255 & $5.38 \pm 0.29$ & 3 & 0.98 & 0.97 & 9.1 & $15.5 \pm 0.8$ \\
\hline & & MB10 & -16.2322 & -68.1178 & 4256 & $5.16 \pm 0.16$ & 3 & 0.98 & 0.97 & 9.0 & $15.0 \pm 0.5$ \\
\hline & & MB11 & -16.2329 & -68.1177 & 4264 & $4.38 \pm 0.16$ & 1 & 0.99 & 0.97 & 8.9 & $12.6 \pm 0.6$ \\
\hline & & MB12 & -16.2330 & -68.1177 & 4265 & $7.82 \pm 0.38$ & 2 & 0.98 & 0.97 & 9.6 & $21.0 \pm 1.0$ \\
\hline & & MB13 & -16.2330 & -68.1177 & 4265 & $3.79 \pm 0.24$ & 2 & 0.98 & 0.97 & 8.8 & $11.1 \pm 0.7$ \\
\hline & & MB14 & -16.2330 & -68.1177 & 4265 & $5.16 \pm 0.26$ & 3 & 0.98 & 0.97 & 9.0 & $14.8 \pm 0.7$ \\
\hline & & Zong-13-01 & -16.2302 & -68.1199 & 4183 & $2.97 \pm 0.11$ & 2 & 0.99 & 0.97 & 8.3 & $9.1 \pm 0.4$ \\
\hline & & Zong-13-02 & -16.2301 & -68.1201 & 4177 & $2.90 \pm 0.11$ & 2 & 0.99 & 0.97 & 8.3 & $9.0 \pm 0.4$ \\
\hline & & Zong-13-03 & -16.2281 & -68.1225 & 4180 & $2.08 \pm 0.10$ & 0.5 & 1.00 & 0.97 & 8.0 & $6.6 \pm 0.3$ \\
\hline & & Zong-13-04 & -16.2300 & -68.1200 & 4191 & $3.43 \pm 0.15$ & 1 & 0.99 & 0.97 & 8.4 & $10.4 \pm 0.5$ \\
\hline \multirow{3}{*}{ IP alpha } & \multirow{3}{*}{ Smith et al., 2005} & ZONG-00-10 & -16.1301 & -68.1902 & 4105 & $5.28 \pm 0.21$ & 5 & 0.96 & 0.99 & 8.5 & $16.1 \pm 0.6$ \\
\hline & & ZONG-00-11 & -16.1301 & -68.1902 & 4105 & $4.66 \pm 0.22$ & 5 & 0.96 & 0.99 & 8.3 & $14.5 \pm 0.6$ \\
\hline & & ZONG-00-12 & -16.1301 & -68.1902 & 4105 & $4.72 \pm 0.16$ & 5 & 0.96 & 0.99 & 8.3 & $14.7 \pm 0.5$ \\
\hline & & CNB1 & -16.2751 & -68.1158 & 4630 & $4.99 \pm 0.31$ & 2 & 0.99 & 0.99 & 10.5 & $12.0 \pm 0.8$ \\
\hline & & CNB2 & -16.2751 & -68.1158 & 4631 & $4.74 \pm 0.16$ & 3 & 0.98 & 0.99 & 10.5 & $11.6 \pm 0.4$ \\
\hline CQ1 & This Study & CNB3 & -16.2750 & -68.1160 & 4630 & $4.85 \pm 0.16$ & 2 & 0.98 & 0.99 & 10.5 & $11.7 \pm 0.4$ \\
\hline & & CNB4 & -16.2750 & -68.1162 & 4628 & $4.56 \pm 0.19$ & 3 & 0.98 & 0.99 & 10.4 & $11.2 \pm 0.5$ \\
\hline & & CNB5 & -16.2750 & -68.1159 & 4629 & $4.76 \pm 0.19$ & 2 & 0.98 & 0.99 & 10.5 & $11.6 \pm 0.5$ \\
\hline & & CNB16 & -16.2749 & -68.1192 & 4486 & $3.77 \pm 0.13$ & 1 & 0.99 & 0.97 & 9.6 & $10.0 \pm 0.4$ \\
\hline & & CNB17 & -16.2748 & -68.1193 & 4488 & $4.15 \pm 0.15$ & 1 & 0.99 & 0.97 & 9.7 & $10.9 \pm 0.4$ \\
\hline $\mathrm{CQ}_{3}$ & This Study & CNB18 & -16.2748 & -68.1191 & 4493 & $4.03 \pm 0.13$ & 1 & 0.99 & 0.97 & 9.7 & $10.6 \pm 0.4$ \\
\hline & & CNB19 & -16.2748 & -68.1190 & 4492 & $4.11 \pm 0.25$ & 1 & 0.99 & 0.97 & 9.7 & $10.8 \pm 0.6$ \\
\hline & & CNB2O & -16.2748 & -68.1192 & 4489 & $3.71 \pm 0.14$ & 2 & 0.99 & 0.98 & 9.6 & $9.8 \pm 0.4$ \\
\hline & & CNB11 & -16.2814 & -68.1148 & 4585 & $3.94 \pm 0.13$ & 2 & 0.98 & 0.95 & 10.1 & $10.2 \pm 0.4$ \\
\hline CQ4 & Jomelli et al., in prep. & CNB13 & -16.2748 & -68.1190 & 4492 & $3.96 \pm 0.17$ & 3 & 0.98 & 0.97 & 9.7 & $10.6 \pm 0.5$ \\
\hline & & CNB15 & -16.2814 & -68.1144 & 4594 & $3.88 \pm 0.13$ & 2 & 0.98 & 0.96 & 10.1 & $10.0 \pm 0.4$ \\
\hline Calculated & ith a density of $2.7 \mathrm{~g} . \mathrm{cn}$ & $\mathrm{m}^{-3}$ and an att & uation len & of $160 \mathrm{~g} \cdot \mathrm{cm}$ & & & & & & & \\
\hline${ }^{b}$ Calculated & using the CRONUS shield & ding applicatio & & & & & & & & & \\
\hline Global scal & $\mathrm{ng}$ factor that accounts $\mathrm{f}$ & for the geoma & tic corre & & & & & & & & \\
\hline
\end{tabular}

643 Table 3. Zongo Valley ${ }^{10}$ Be CRE age results. Recalculated ages from Cerro Telata (Jomelli et al., 2011) 644 are presented in the Supplementary Information (Table Sla) as well as the raw ${ }^{10} \mathrm{Be}$ and ${ }^{9} \mathrm{Be}$ 645 measurements of the new samples (Table S1b). 

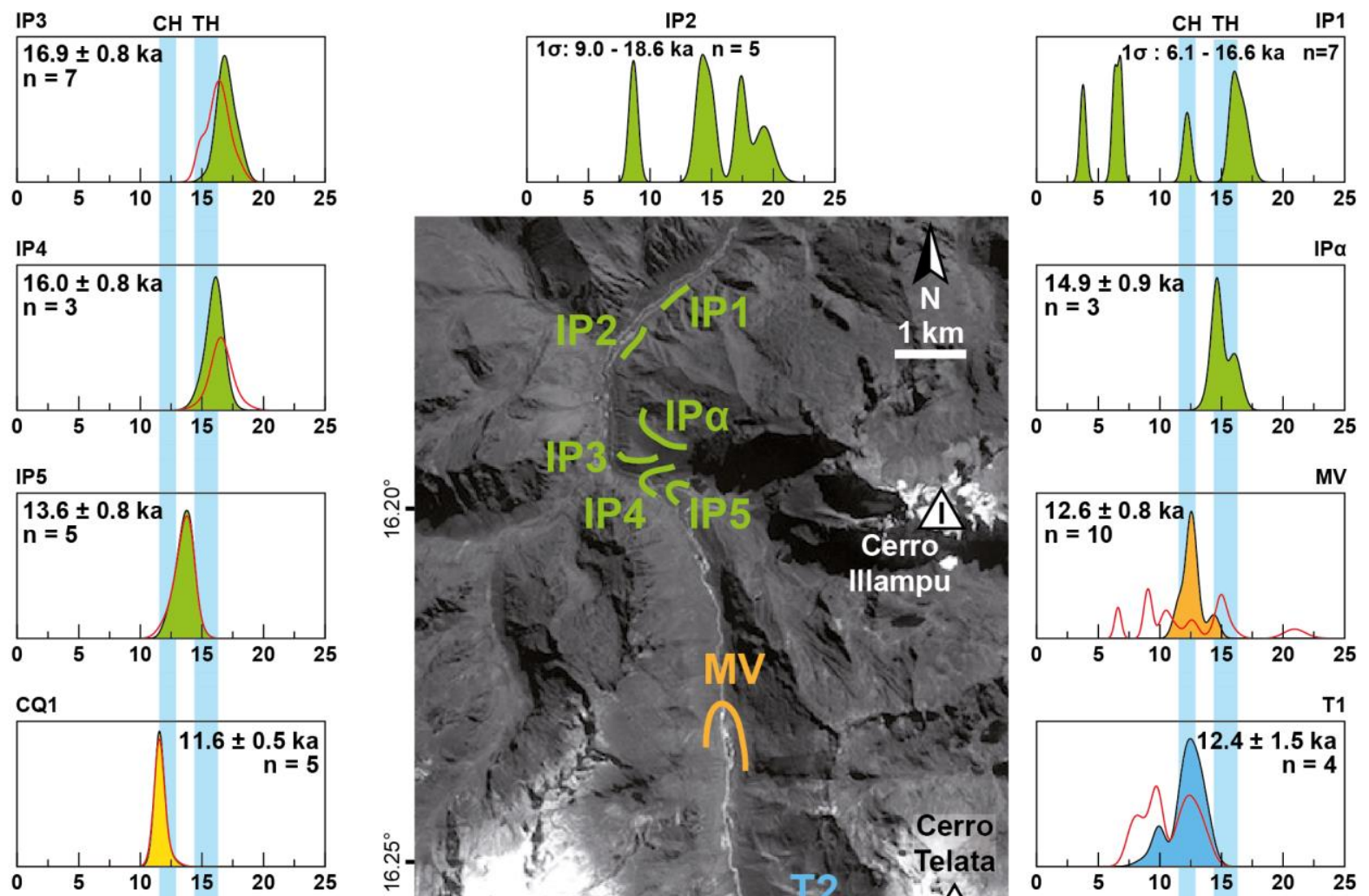

CQ3
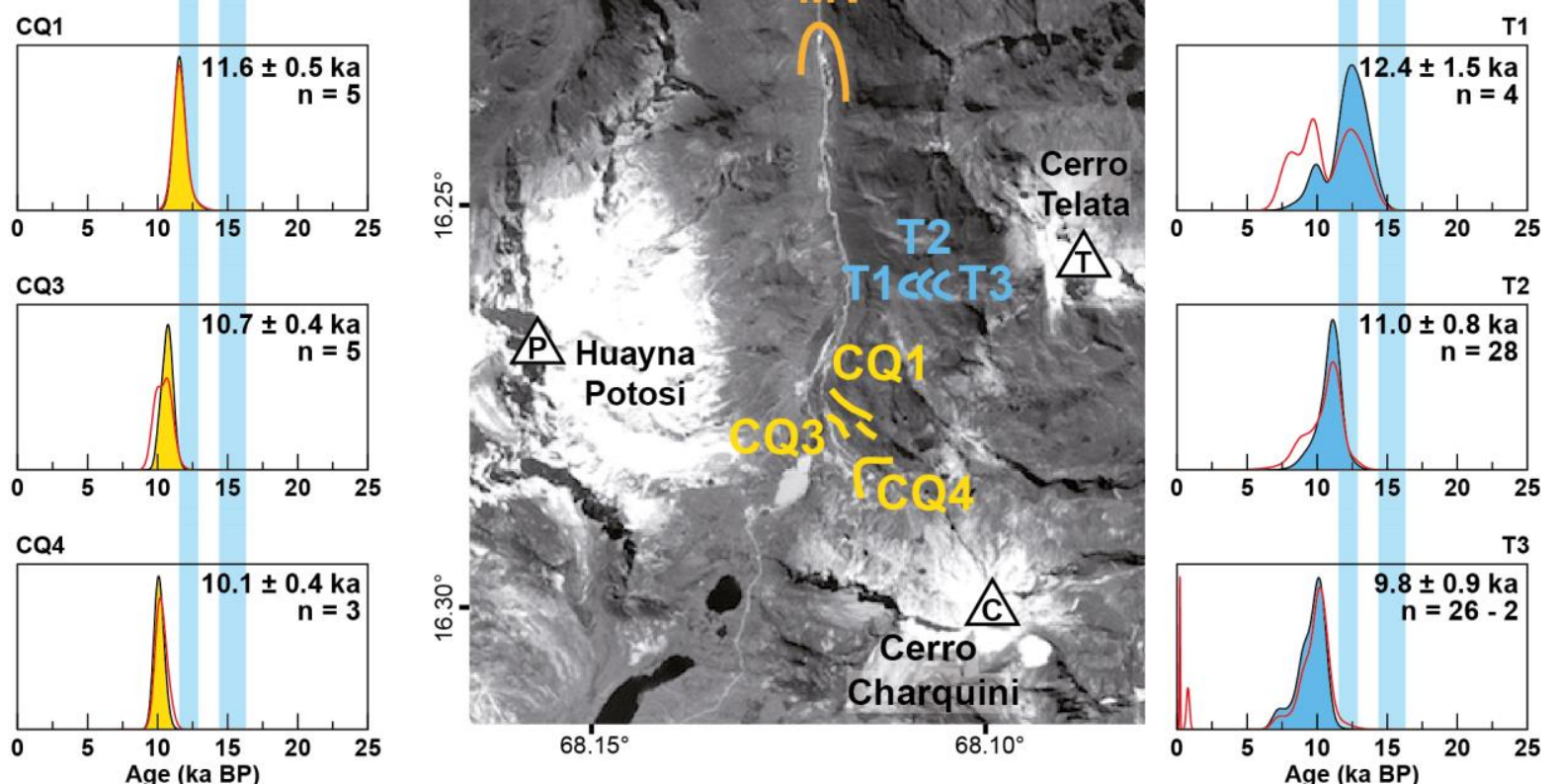

Figure 12. Moraine ${ }^{10}$ Be CRE ages in Zongo Valley. The age PDFs of each moraine are color coded to the map colors. For each PDF, the median age and mean $1 \sigma$ range are indicated. Boulder ages contributing to the moraine PDFs beyond $25 \mathrm{ka} B P$ are not represented. Red curves are the raw PDFs before Bayesian processing, and the shaded histograms are the final PDFs from which ages were derived (see Section 3.1.5). For moraines IPI and IP2, the scatter is too important to propose a relevant central value, and only the central $1 \sigma$ range is indicated. ' $n$ ' indicates the number of samples. When $n$ is reported as ' $n=A-B$ ', $A$ is the total number of boulders dated on the moraine and $B$ is the number of boulders considered to be outliers. The blue bars labeled ' $T H$ ' and 'CH' indicate the Tauca and 
658 M0 show important scatter; imposing the Bayesian condition that M1 is younger does not substantially 659 narrow the age distribution, which finally yields an age of $16.1 \pm 1.5 \mathrm{ka}$ BP. The M1 age PDF comprises 660 a main peak at c. $15 \mathrm{ka} \mathrm{BP}$, corresponding to four statistically consistent boulder ages, and two minor 661 peaks corresponding to two older single-boulder ages at 19 and $29 \mathrm{ka} \mathrm{BP}$. We attributed these two older 662 ages to the production of ${ }^{3} \mathrm{He}$ in these blocks prior to their deposition atop the moraine (i.e. inheritance) 663 and thus consider them to be outliers. After Bayesian processing using M0 and M2 as respectively older 664 and younger objects, the age PDF computed from the four main-peak samples gives an age of $15.3 \pm$ $6650.7 \mathrm{ka}$ BP. The raw age distribution of M2 presents important scatter; imposing the Bayesian conditions 666 that M1 and M3 are respectively older and younger narrows its age range to $15.1 \pm 0.8 \mathrm{ka} \mathrm{BP}$.

667 The four boulders of M3 yielded clustered ages, with the Bayesian processing only marginally 668 refining the PDF to yield an age of $14.9 \pm 0.8 \mathrm{ka} \mathrm{BP}$. The M4 age is based on a single boulder (SAJ-8) 669 whose age of $11.8 \pm 0.7 \mathrm{ka}$ BP is coherent with the ages of the younger SAJ-7 roche moutonnée (10.8 $670 \pm 0.5 \mathrm{ka} \mathrm{BP})$ and the older M3 moraine. The ages of the SAJPH-8 roches moutonnées $(15.1 \pm 0.7 \mathrm{ka}$ 671 BP) is in good agreement with the moraine ages, whereas SAJPH-7 yields an age that is several thousand 672 years younger than the well-established age of M3. Therefore, SAJPH-7 is probably at odds with the 673 global chronology and must have been affected by shielding, either by remnants of basal till or by 674 hillslope colluvium. 


\begin{tabular}{|c|c|c|c|c|c|c|c|c|c|c|c|c|c|c|c|c|}
\hline $\begin{array}{l}\text { Glacial } \\
\text { Feature }\end{array}$ & Source & Sample & $\begin{array}{l}\text { Latitude } \\
\text { Dec }^{\circ} \\
\end{array}$ & $\begin{array}{c}\text { Longitude } \\
\text { Dec }^{\circ} \\
\end{array}$ & $\begin{array}{l}\text { Altitude } \\
\text { masl }\end{array}$ & $\begin{array}{l}\text { Pyroxene } \\
\text { Color }\end{array}$ & $\begin{array}{c}\mathrm{Li} \\
p p m\end{array}$ & $\begin{array}{c}\text { Eruption age } \\
\qquad M a\end{array}$ & $\begin{array}{c}\mathrm{Pn} \\
\text { at. } g^{-4} \cdot y r^{-1} \\
\end{array}$ & $\begin{array}{c}{ }^{3} \mathrm{He}_{\mathrm{n}} \\
10^{5} \text { at. }^{-1 .} \\
\end{array}$ & $\begin{array}{c}{ }^{3} \mathrm{He}_{c}(1 \boldsymbol{\sigma})^{6} \\
10^{7} \text { at. } g^{-1}\end{array}$ & $\begin{array}{c}\text { Thickness } \\
\mathrm{cm}\end{array}$ & $\begin{array}{c}\text { Thick. Corr. } \\
.\end{array}$ & Shielding ${ }^{d}$ & $\begin{array}{c}\text { Scaling Factor } \\
\end{array}$ & $\begin{array}{l}\text { Age (10)' } \\
k a\end{array}$ \\
\hline \multirow{5}{*}{ мо } & \multirow{5}{*}{ This study } & SA 1 & -18.1817 & -68.8494 & 4400 & Black & 68 & 4.9 & 0.17 & 8.55 & $2.06 \pm 0.09$ & 2.0 & 0.98 & 1.00 & 10.03 & $15.7 \pm 0.7$ \\
\hline & & SAJ 2 & -18.1813 & -68.8496 & 4407 & Black & 21 & 3.5 & 0.06 & 2.04 & $1.90 \pm 0.14$ & 1.0 & 0.99 & 1.00 & 9.90 & $14.6 \pm 1.0$ \\
\hline & & SAJ PH 1 & -18.1823 & -68.8451 & 4422 & Black & 15 & 3.5 & 0.05 & 1.77 & $1.77 \pm 0.20$ & 1.0 & 0.99 & 1.00 & 9.87 & $13.6 \pm 1.5$ \\
\hline & & SAJ PH 2 & -18.1820 & -68.8452 & 4436 & Black & 28 & 3.8 & 0.10 & 3.69 & $1.83 \pm 0.09$ & 1.5 & 0.99 & 1.00 & 9.95 & $14.0 \pm 0.8$ \\
\hline & & SAJ PH 3 & -18.1779 & -68.8458 & 4498 & Black & 51 & 4.4 & 0.17 & 7.37 & $2.47 \pm 0.12$ & 2.0 & 0.98 & 1.00 & 10.71 & $17.6 \pm 0.9$ \\
\hline \multirow{7}{*}{ M1 } & \multirow{7}{*}{ Martin et al., 2018} & $\mathrm{SAJ} 3$ & -18.1761 & -68.8505 & 4532 & Black & 67 & 0.2 & 2.10 & 4.16 & $2.14 \pm 0.11$ & 1.5 & 0.99 & 1.00 & 10.61 & $15.4 \pm 0.8$ \\
\hline & & SAJ $3-R$ & -18.1761 & -68.8505 & 4532 & Green & 47 & 0.2 & 1.48 & 3.22 & $2.15 \pm 0.14$ & 1.5 & 0.99 & 1.00 & 10.62 & $15.4 \pm 0.9$ \\
\hline & & SAJ 4 & -18.1761 & -68.8505 & 4532 & Black & 54 & 0.2 & 0.82 & 1.78 & $1.86 \pm 0.09$ & 2.0 & 0.98 & 1.00 & 10.37 & $13.7 \pm 0.8$ \\
\hline & & SAJ 5 & -18.1734 & -68.8510 & 4570 & Black & 115 & 0.3 & 1.88 & 5.37 & $2.26 \pm 0.11$ & 1.0 & 0.99 & 1.00 & 10.86 & $15.8 \pm 0.8$ \\
\hline & & SAJ 6 & -18.1717 & -68.8516 & 4580 & Black & 53 & 0.3 & 0.90 & 2.31 & $2.13 \pm 0.10$ & 3.0 & 0.97 & 1.00 & 10.81 & $15.2 \pm 0.7$ \\
\hline & & SAJ PH 4 & -18.1755 & -68.8456 & 4527 & Black & 43 & 4.1 & 0.14 & 5.58 & $4.42 \pm 0.18$ & 1.0 & 0.99 & 1.00 & 11.44 & $29.2 \pm 1.6$ \\
\hline & & SAJ PH 5 & -18.1771 & -68.8464 & 4480 & Black & 148 & 2.9 & 0.46 & 13.19 & $2.75 \pm 0.12$ & 2.0 & 0.98 & 1.00 & 10.83 & $19.4 \pm 0.9$ \\
\hline \multirow{5}{*}{ M2 } & \multirow{5}{*}{ This study } & SAJ PH 9 & -18.1632 & -68.8474 & 4584 & Black & 52 & 5.6 & 0.17 & 9.72 & $3.90 \pm 0.14$ & 0.5 & 1.00 & 0.99 & 11.48 & $25.6 \pm 1.1$ \\
\hline & & SAJ PH 10 & -18.1632 & -68.8474 & 4584 & Black & 89 & 0.6 & 0.20 & 1.15 & $3.44 \pm 0.17$ & 1.0 & 0.99 & 0.99 & 11.61 & $22.4 \pm 1.4$ \\
\hline & & SAJ PH 11 & -18.1632 & -68.8477 & 4578 & Black & 43 & 4.6 & 0.15 & 6.91 & $2.02 \pm 0.07$ & 0.5 & 1.00 & 0.99 & 10.65 & $14.3 \pm 0.6$ \\
\hline & & SAJ PH 12 & -18.1637 & -68.8476 & 4569 & Black & 99 & 5.5 & 0.32 & 17.50 & $2.23 \pm 0.10$ & 3.0 & 0.97 & 0.99 & 10.85 & $15.8 \pm 0.7$ \\
\hline & & SAJ PH 13 & -18.1643 & -68.8478 & 4565 & Black & 27 & 3.8 & 0.08 & 2.88 & $2.56 \pm 0.12$ & 1.5 & 0.99 & 0.99 & 11.03 & $17.6 \pm 0.8$ \\
\hline \multirow{2}{*}{$\begin{array}{c}\text { Roches } \\
\text { Moutonnées }\end{array}$} & \multirow[b]{2}{*}{ This study } & SAJ PH 8 & -18.1617 & -68.8510 & 4545 & Black & 65 & 7.6 & 0.20 & 15.54 & $2.10 \pm 0.10$ & 2.0 & 0.98 & 0.99 & 10.63 & $15.1 \pm 0.7$ \\
\hline & & SAJ PH 7 & -18.1565 & -68.8514 & 4593 & Black & 33 & 7.2 & 0.09 & 6.48 & $1.61 \pm 0.09$ & 3.0 & 0.97 & 0.99 & 10.61 & $11.7 \pm 0.7$ \\
\hline \multirow{6}{*}{ M3 } & \multirow{6}{*}{ This study } & SAJ 9 & -18.1518 & -68.8553 & 4662 & Black & 126 & 0.2 & 2.05 & 3.94 & $2.24 \pm 0.12$ & 1.5 & 0.99 & 1.00 & 11.21 & $15.2 \pm 0.8$ \\
\hline & & SAJ 10 & -18.1518 & -68.8550 & 4660 & Black & 68 & 0.4 & 1.88 & 8.27 & $2.27 \pm 0.14$ & 1.0 & 0.99 & 1.00 & 11.22 & $15.4 \pm 0.9$ \\
\hline & & SAJ $10-R$ & -18.1518 & -68.8550 & 4660 & Green & 24 & 0.5 & 0.66 & 3.45 & $2.15 \pm 0.12$ & 1.0 & 0.99 & 1.00 & 11.10 & $14.7 \pm 0.8$ \\
\hline & & SAJ 11 & -18.1532 & -68.8534 & 4640 & Black & 36 & 0.4 & 0.19 & 0.82 & $2.25 \pm 0.15$ & 1.5 & 0.99 & 1.00 & 11.12 & $15.4 \pm 0.9$ \\
\hline & & SAJ $11-R$ & -18.1532 & -68.8534 & 4640 & Green & 8 & 0.5 & 0.04 & 0.21 & $2.26 \pm 0.15$ & 1.5 & 0.99 & 1.00 & 11.14 & $15.4 \pm 1.0$ \\
\hline & & SAJ PH 6 & -18.1555 & -68.8516 & 4604 & Black \& Green & 22 & 0.4 & 0.13 & 0.56 & $2.06 \pm 0.10$ & 0.5 & 1.00 & 0.99 & 10.78 & $14.4 \pm 0.7$ \\
\hline M4 & This study & SAJ 8 & -18.1485 & -68.8552 & 4670 & Black \& Green & 25 & 0.2 & 0.31 & 0.71 & $1.70 \pm 0.09$ & 1.5 & 0.99 & 1.00 & 10.98 & $11.8 \pm 0.7$ \\
\hline R. Mout. & This study & SAJ 7 & -18.1413 & -68.8535 & 4706 & Black & 16 & 5.1 & 0.07 & 3.65 & $1.57 \pm 0.06$ & 1.0 & 0.99 & 0.99 & 11.01 & $10.8 \pm 0.5$ \\
\hline
\end{tabular}

$R$ replicate. For the sample from this study, replicates have been used to compare ${ }^{3}$ He concentrations from black and green pyroxenes

" $(\mathrm{U}$-Th-Sm) $/$ He age

${ }^{\circ} \mathrm{He}_{\mathrm{c}}=\mathrm{He}_{\mathrm{tex}}-\mathrm{He}_{n}-\mathrm{He}_{m}$ (we considered $\mathrm{He}_{m}=8.5 \times 10^{4}$ at. $\mathrm{g}^{-4}$ for all samples)

'Calculated with a density of $2.7 \mathrm{~g} \mathrm{.cm}$ and an attenuation length of $160 \mathrm{~g} \mathrm{~cm}^{-2}$

Shielding is negligible

-Global saling factor that accounts for the geomagnetic correction

676 Table 4. Nevado Sajama ${ }^{3}$ He CRE age results. 

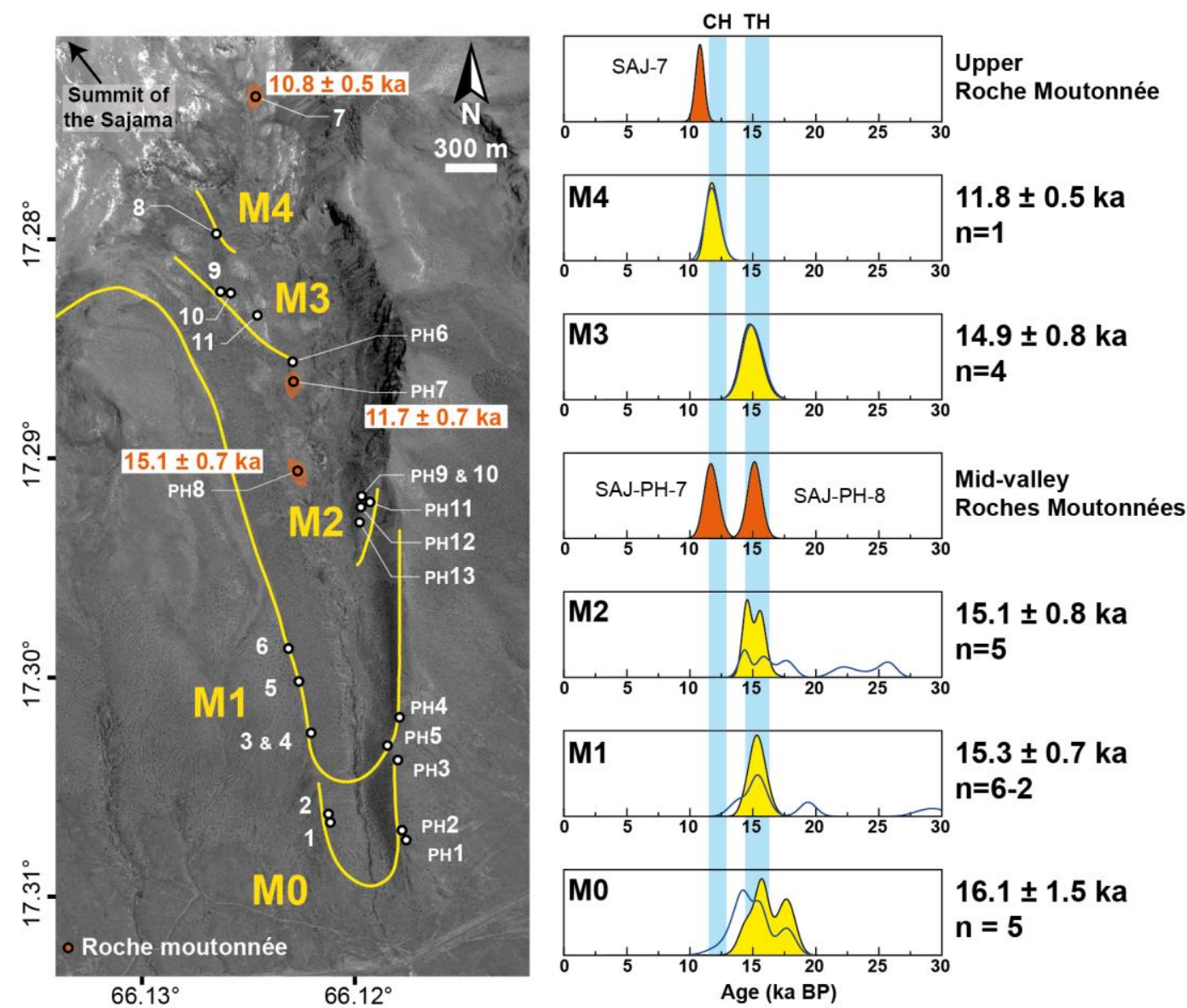

Figure 13. ${ }^{3} \mathrm{He} C R E$ ages on Nevado Sajama. Uncertainties are $1 \sigma$. The age PDF of each moraine is 679 reported in yellow. Boulder ages contributing to moraine PDFs beyond $30 \mathrm{ka}$ BP are not represented. 680 Roches moutonnées and their age distributions are reported on the map in orange. For each PDF, the 681 median age is reported. ' $n$ ' indicates the number of samples; when $n$ is reported as ' $n=A-B$ ', $A$ is the total number of boulders dated on the moraine and $B$ is the number of boulders considered to be outliers. Blue curves are the raw PDFs before Bayesian processing, and the shaded histograms are the final PDFs from which ages were derived (see Section 3.1.5). Blue bars labeled 'TH' and ' $\mathrm{CH}$ ' indicate the Tauca and Coipasa highstands, respectively.

\subsection{4. ${ }^{3}$ He moraine chronology of Cerro Tunupa}


696 the mid-valley roches moutonnées TU-2 and TU-4 are older partly narrows the M3 age distribution, 697 yielding an age of $13.4 \pm 1.1 \mathrm{ka}$ BP. Three roches moutonnées (TU-2, TU-4, TU-13-203) yield ages 698 clustered around 15.2-15.5 ka BP, and one (TU-13-04) a much older age of $21.9 \pm 1.3 \mathrm{ka}$ BP; this 699 probably indicates an inherited ${ }^{3} \mathrm{He}$ component. Given that moraine M3 is deposited above roches 700 moutonnées TU-2 and TU-13-203, it must have formed during a glacial re-advance (13-12.5 ka BP) 701 that occurred after the deglaciation at $15.2 \mathrm{ka} \mathrm{BP.}$ 


\begin{tabular}{|c|c|c|c|c|c|c|c|c|c|c|c|c|c|c|c|c|}
\hline $\begin{array}{l}\text { Glacial } \\
\text { Feature }\end{array}$ & Source & Sample & $\begin{array}{l}\text { Latitude } \\
\text { Dec }^{\circ}\end{array}$ & $\begin{array}{l}\text { Longitude } \\
\text { Dec }^{\circ}\end{array}$ & $\begin{array}{l}\text { Altitude } \\
\text { masl }\end{array}$ & $\begin{array}{c}\text { Pyroxene } \\
\text { Color }\end{array}$ & $\begin{array}{c}\mathrm{Li} \\
p p m\end{array}$ & $\begin{array}{l}\text { Eruption age } \\
\qquad M a\end{array}$ & $\begin{array}{c}\mathrm{Pn} \\
\text { at. }^{-1} \cdot y r^{-1}\end{array}$ & $\begin{array}{c}{ }^{3} \mathrm{He}_{\mathrm{n}} \\
10^{5} \text { atg }^{-1}\end{array}$ & $\begin{array}{c}{ }^{3} \mathrm{He}_{\mathrm{c}}(1 \sigma)^{b} \\
10^{7} \text { at. } g^{-1}\end{array}$ & $\begin{array}{c}\text { Thickness } \\
\mathrm{cm}\end{array}$ & Thick. Corr.' & Shielding $^{d}$ & Scaling Factor & $\begin{array}{l}\text { Age (10) } \\
k a\end{array}$ \\
\hline \multirow{5}{*}{ M1 } & \multirow{5}{*}{ Blard et al., 2009} & TU-124 & -19.8586 & -67.6138 & 4292 & - & - & - & . & . & $1.99 \pm 0.08$ & 2.2 & 0.98 & 1.00 & 9.7 & $15.7 \pm 0.7$ \\
\hline & & TU-1A & -19.8643 & -67.6128 & 4260 & . & . & . & . & . & $2.02 \pm 0.06$ & 3.3 & 0.97 & 1.00 & 9.7 & $16.2 \pm 0.6$ \\
\hline & & TU-1B & -19.8638 & -67.6144 & 4290 & . & . & . & . & . & $2.21 \pm 0.07$ & 2.2 & 0.98 & 1.00 & 9.9 & $17.1 \pm 0.7$ \\
\hline & & TU-1Cf & -19.8652 & -67.6099 & 4206 & - & - & - & . & . & $2.96 \pm 0.13$ & 3.3 & 0.97 & 1.00 & 9.9 & $23.1 \pm 1.4$ \\
\hline & & TU-1D & -19.8691 & -67.6054 & 4083 & - & - & - & - & - & $1.83 \pm 0.06$ & 5.5 & 0.95 & 1.00 & 8.9 & $16.2 \pm 0.7$ \\
\hline \multirow{6}{*}{ M2 } & \multirow{6}{*}{ Blard et al., 2009} & TU-119 & -19.8599 & -67.6138 & 4250 & - & - & - & . & - & $1.83 \pm 0.06$ & 0.5 & 1.00 & 0.99 & 9.4 & $14.7 \pm 0.6$ \\
\hline & & TU-120 & -19.8599 & -67.6138 & 4250 & - & - & - & - & - & $1.79 \pm 0.06$ & 0.5 & 1.00 & 0.99 & 9.4 & $14.4 \pm 0.6$ \\
\hline & & TU-121 & -19.8590 & -67.6147 & 4267 & - & - & - & - & - & $1.87 \pm 0.13$ & 0.5 & 1.00 & 0.99 & 9.5 & $14.8 \pm 0.9$ \\
\hline & & TU-121 - R & -19.8590 & -67.6147 & 4267 & - & - & - & - & - & $1.96 \pm 0.09$ & 0.5 & 1.00 & 0.99 & 9.6 & $15.4 \pm 0.7$ \\
\hline & & TU-122 & -19.8590 & -67.6147 & 4267 & - & - & - & - & - & $1.74 \pm 0.10$ & 0.5 & 1.00 & 0.99 & 9.4 & $14.0 \pm 0.8$ \\
\hline & & TU-123 & -19.8588 & -67.6149 & 4275 & - & - & - & - & - & $1.31 \pm 0.05$ & 0.5 & 1.00 & 0.98 & 9.2 & $10.7 \pm 0.5$ \\
\hline \multirow{4}{*}{$\begin{array}{c}\text { Roches } \\
\text { Moutonnées }\end{array}$} & Blard et al., 2009 & TU-4 & -19.8570 & -67.6180 & 4260 & - & - & - & - & - & $1.89 \pm 0.07$ & 2.2 & 0.98 & 0.98 & 9.6 & $15.5 \pm 0.6$ \\
\hline & Blard et al., 2009 & TU-2 & -19.8455 & -67.6272 & 4450 & - & - & - & - & - & $2.08 \pm 0.06$ & 3.3 & 0.97 & 0.98 & 10.5 & $15.7 \pm 0.6$ \\
\hline & \multirow{2}{*}{ This Study } & TU-13-04 & -19.8430 & -67.6271 & 4461 & Black & 87 & 1.20 & 0.3297 & $3.96 \mathrm{E}+05$ & $3.19 \pm 0.17$ & 2.8 & 0.98 & 0.98 & 11.2 & $21.9 \pm 1.3$ \\
\hline & & TU-13-203 & -19.8442 & -67.6278 & 4462 & Black & 66 & 1.38 & 0.2545 & $3.51 E+05$ & $2.04 \pm 0.10$ & 5.0 & 0.96 & 0.98 & 10.5 & $15.3 \pm 0.7$ \\
\hline \multirow{11}{*}{ M3 } & \multirow{4}{*}{ Blard et al., 2009} & TU-3A & -19.8446 & -67.6259 & 4415 & - & - & - & - & - & $1.57 \pm 0.06$ & 2.2 & 0.98 & 0.98 & 10.0 & $12.2 \pm 0.6$ \\
\hline & & TU-3A - R & -19.8446 & -67.6259 & 4415 & - & - & - & - & - & $1.63 \pm 0.07$ & 2.2 & 0.98 & 0.98 & 10.0 & $12.7 \pm 0.7$ \\
\hline & & TU-3B & -19.8446 & -67.6259 & 4415 & - & - & - & - & - & $1.81 \pm 0.05$ & 2.2 & 0.98 & 0.98 & 10.1 & $14.1 \pm 0.5$ \\
\hline & & TU-13-201 & -19.8443 & -67.6268 & 4432 & Black & 51 & 0.57 & 0.4736 & $2.71 E+05$ & $1.86 \pm 0.11$ & 1.7 & 0.99 & 0.98 & 10.1 & $14.0 \pm 0.8$ \\
\hline & \multirow{7}{*}{ This Study } & TU-13-201 - R & -19.8443 & -67.6268 & 4432 & Green & 45 & 1.72 & 0.4179 & $7.18 \mathrm{E}+05$ & $1.65 \pm 0.07$ & 1.7 & 0.99 & 0.98 & 10.1 & $12.4 \pm 0.7$ \\
\hline & & TU-13-202 & -19.8441 & -67.6275 & 4457 & Green & 50 & 2.06 & 0.3340 & $6.88 \mathrm{E}+05$ & $2.36 \pm 0.09$ & 5.0 & 0.96 & 0.98 & 10.7 & $17.3 \pm 0.8$ \\
\hline & & TU-13-204 & -19.8447 & -67.6276 & 4456 & Black & 51 & 0.84 & 0.4651 & $3.92 E+05$ & $1.76 \pm 0.10$ & 5.0 & 0.96 & 0.98 & 10.2 & $13.5 \pm 0.8$ \\
\hline & & TU-13-204 - R & -19.8447 & -67.6276 & 4456 & Green & 48 & 1.70 & 0.4378 & $7.43 E+05$ & $1.65 \pm 0.07$ & 2.2 & 0.98 & 0.98 & 10.2 & $12.4 \pm 0.6$ \\
\hline & & TU-13-01 & -19.8424 & -67.6286 & 4502 & Black & 61 & 1.27 & 0.2345 & $2.98 \mathrm{E}+05$ & $2.15 \pm 0.12$ & 3.9 & 0.97 & 0.99 & 10.7 & $15.6 \pm 0.8$ \\
\hline & & TU-13-02 & -19.8426 & -67.6278 & 4480 & Black & 54 & 1.49 & 0.2092 & $3.11 E+05$ & $2.36 \pm 0.12$ & 2.2 & 0.98 & 0.99 & 10.8 & $16.8 \pm 0.9$ \\
\hline & & TU-13-03 & -19.8426 & -67.6275 & 4467 & Black & 48 & 1.49 & 0.1773 & $2.65 E+05$ & $3.23 \pm 0.17$ & 4.5 & 0.96 & 0.98 & 11.2 & $22.5 \pm 1.5$ \\
\hline
\end{tabular}

$R$ replicate. For the sample from this study, replicates have been used to compare ${ }^{3}$ He concentrations from black and green pyroxenes

(U-Th-Sm) $\hat{r}^{4}$ He age

${ }^{\circ} \mathrm{He}_{\mathrm{c}}=\mathrm{He}_{\mathrm{tot}}-\mathrm{He}_{n}-\mathrm{He}_{m}$ (we considered $\mathrm{He}_{m}=8.5 \times 10^{4}$ at. ${ }^{-4}$ for all samples)

'Calculated with a density of $2.7 \mathrm{~g} . \mathrm{cm}^{-3}$ and an attenuation length of $160 \mathrm{~g} . \mathrm{cm}^{-2}$

Shielding from Blard et al. (2009) calculated with the CRONUS application, shielding for samples from this study is negligible

"Global scaling factor that accounts for the geomagnetic correction

703 'SLHL PR: weighted mean of the rates from Blard et al. (2013a) and Delunel et al. (2016) - Scaling scheme: Lal modified - Atmosphere: ERA40 - VDM: Muscheler et al. (2005)

704 Table 5. Cerro Tunupa ${ }^{3} \mathrm{He}$ CRE age results. 


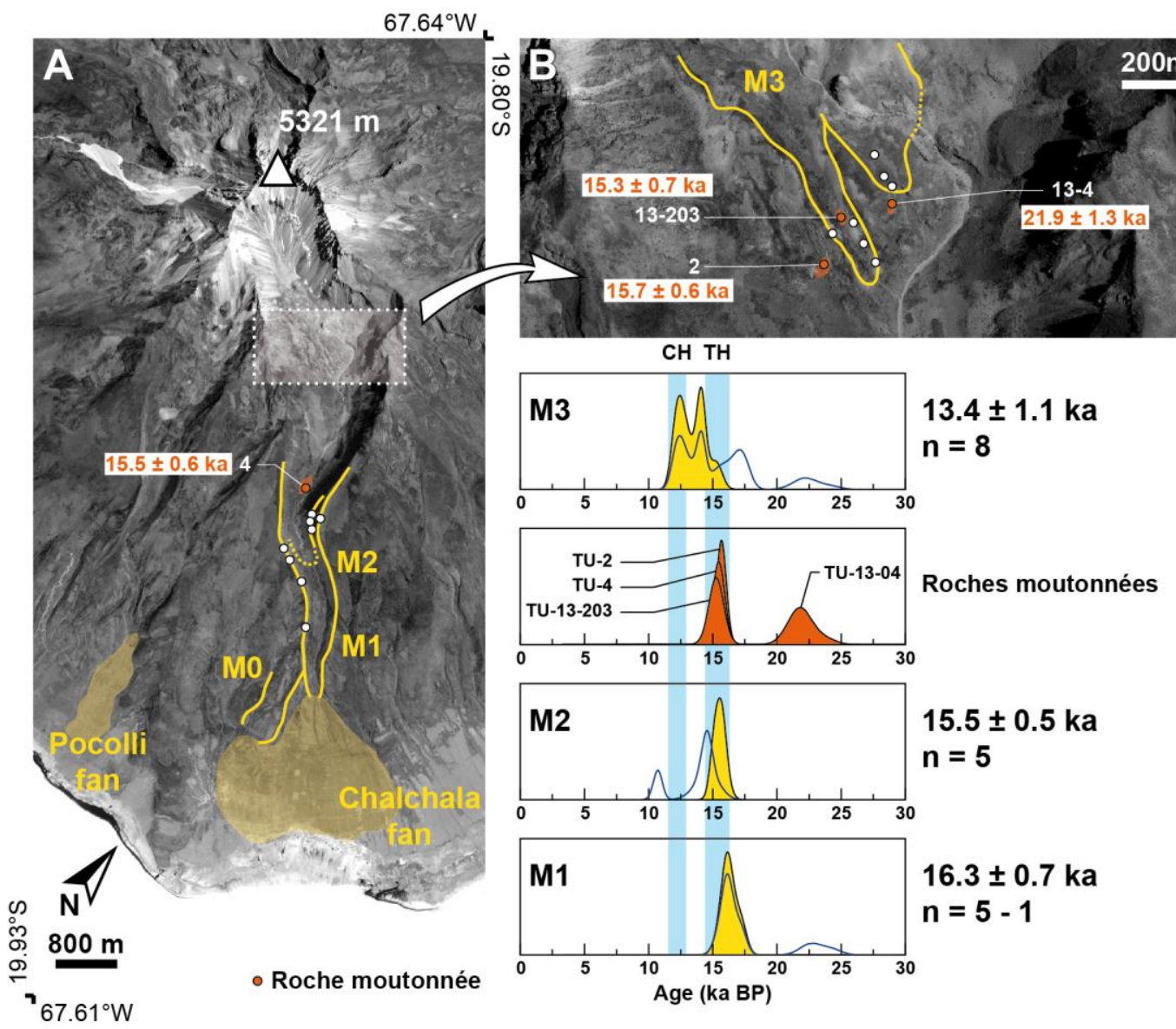

Figure 14. ${ }^{3}$ He CRE ages on Cerro Tunupa. Uncertainties are $1 \sigma$. The age PDF is reported in yellow for each moraine. Boulder ages contributing to the moraine PDF beyond $30 \mathrm{ka} \mathrm{BP}$ are not represented. Roche moutonnées and their age distributions are reported on the map in orange. The median age is reported for each $P D F$. ' $n$ ' indicates the number of samples; when $n$ is reported as ' $n=A-B$ ', $A$ is the total number of boulders dated on the moraine and $B$ is the number of boulders considered to be outliers. Blue curves are the raw PDFs before Bayesian processing, and the shaded histograms are the final PDFs from which ages were derived (see Section 3.1.5). Blue bars labeled 'TH' and ' $\mathrm{CH}$ ' indicate the Tauca and Coipasa highstands, respectively.

\subsection{5. ${ }^{3}$ He moraine chronology of Cerro Luxar}

CRE age results from Cerro Luxar are presented in Table 6 and Figure 15. The age results at

718 For moraine M1, four clustered boulder ages form a major peak around 16 ka BP and the other six

719 boulders returned distinct ages between 21 and $150 \mathrm{ka} \mathrm{BP}$ (data are only reported to $30 \mathrm{ka}$ BP in Fig. 15). Five of these six older boulders lie atop frontal moraine branches (Fig. 15); subtle inflections of the moraine crest and changes in boulder density suggest that this distal part may be distinct from M1 and

722 thus associated with an older moraine. We therefore consider these six boulders as outliers with 
723 significant inherited ${ }^{3} \mathrm{He}$ components. Imposing the Bayesian condition that M2 is younger than M1, the 724 four remaining samples yield an age of $16.6 \pm 0.7 \mathrm{ka}$ BP for M1.

M2 presents an obvious outlier at $26 \mathrm{ka} \mathrm{BP}$ and a bi-modal peak distribution with the major

726 peak at $17.5 \mathrm{ka} \mathrm{BP}(n=3)$ and the minor peak at $15.5 \mathrm{ka} \mathrm{BP}(n=2)$. Imposing the Bayesian condition 727 that M1 is older and the roches moutonnées LUX-6 and LUX-7 are younger than M2 narrows the age 728 distribution and yields an age of $15.7 \pm 0.8 \mathrm{ka} \mathrm{BP}$. The two upper roches moutonnées LUX-6 and LUX7297 have well-clustered ${ }^{3} \mathrm{He}$ ages, indicating a deglaciation of Cerro Luxar around $14.9 \mathrm{ka}$ BP, coeval with 730 the end of the Lake Tauca highstand. The two boulder ages of M3 lie around $20 \mathrm{ka} \mathrm{BP}$ and are not 731 consistent with the younger ages (15 ka BP) of the stratigraphically older moraines M1 and M2. We 732 therefore discarded these two boulder ages and derived a Bayesian age distribution for M3 from the 733 PDFs of M2 and the roches moutonnées, considering that M3 is younger than M2 and older than the 734 roches moutonnées (see Section 3.1.5). This derived PDF yields an age of $15.3 \pm 0.7 \mathrm{ka}$ BP. 


\begin{tabular}{|c|c|c|c|c|c|c|c|c|c|c|c|c|}
\hline $\begin{array}{l}\text { Glacial } \\
\text { Feature }\end{array}$ & Source & Sample & $\begin{array}{l}\text { Latitude } \\
\operatorname{Dec}^{\circ}\end{array}$ & $\begin{array}{c}\text { Longitude } \\
\mathrm{Dec}^{\circ}\end{array}$ & $\begin{array}{l}\text { Altitude } \\
\text { masl }\end{array}$ & $\begin{array}{c}{ }^{3} \mathbf{H e}_{\mathrm{n}}{ }^{\mathbf{a}} \\
10^{5} \text { at. } g^{-1} \\
\end{array}$ & $\begin{array}{l}{ }^{3} \mathrm{He}_{\mathrm{c}}(\mathbf{1 \sigma})^{\mathrm{b}} \\
10^{7} \text { at. } g^{-1} \\
\end{array}$ & $\begin{array}{c}\text { Thickness } \\
\mathrm{cm}\end{array}$ & $\begin{array}{c}\text { Thick. Corr. } \\
\text { - } \\
\end{array}$ & $\begin{array}{c}\text { Shielding } \\
- \\
\end{array}$ & $\begin{array}{c}\text { Scaling Factor }^{\mathrm{d}} \\
- \\
\end{array}$ & $\begin{array}{c}\text { Age }(\mathbf{1} \sigma)^{\mathrm{e}} \\
k a\end{array}$ \\
\hline \multirow{10}{*}{ M1 } & \multirow{10}{*}{ Martin et al., 2018} & LUX-1 & -21.0096 & -68.0129 & 4230 & 3.18 & $7.22 \pm 0.18$ & 1.0 & 0.99 & 0.99 & 10.8 & $50.8 \pm 2.7$ \\
\hline & & LUX-2 & -21.0094 & -68.0132 & 4236 & 3.18 & $4.46 \pm 0.17$ & 4.0 & 0.97 & 0.99 & 10.3 & $33.7 \pm 1.7$ \\
\hline & & LUX-3 & -21.0091 & -68.0139 & 4263 & 3.18 & $9.39 \pm 0.34$ & 1.5 & 0.99 & 0.99 & 10.9 & $65.4 \pm 3.2$ \\
\hline & & LUX-10 & -21.0085 & -68.0128 & 4228 & 3.18 & $3.26 \pm 0.11$ & 2.0 & 0.98 & 0.99 & 10.1 & $24.6 \pm 1.2$ \\
\hline & & LUX-11 & -21.0084 & -68.0131 & 4244 & 3.18 & $2.19 \pm 0.08$ & 1.5 & 0.99 & 0.99 & 9.9 & $16.9 \pm 0.7$ \\
\hline & & LUX-12 & -21.0080 & -68.0135 & 4265 & 3.18 & $21.66 \pm 0.54$ & 1.5 & 0.99 & 0.99 & 10.9 & $150.6 \pm 7.1$ \\
\hline & & LUX-11-1 & -21.0054 & -68.0158 & 4384 & 3.18 & $2.15 \pm 0.09$ & 2.0 & 0.98 & 0.99 & 10.4 & $15.8 \pm 0.7$ \\
\hline & & LUX-11-2 & -21.0047 & -68.0164 & 4418 & 3.18 & $2.04 \pm 0.07$ & 2.0 & 0.98 & 0.99 & 10.4 & $15.0 \pm 0.6$ \\
\hline & & LUX-11-3 & -21.0043 & -68.0167 & 4429 & 3.18 & $2.31 \pm 0.06$ & 2.0 & 0.98 & 0.99 & 10.7 & $16.5 \pm 0.6$ \\
\hline & & LUX-11-4 & -21.0039 & -68.0170 & 4440 & 3.18 & $3.03 \pm 0.09$ & 2.0 & 0.98 & 0.99 & 11.2 & $20.6 \pm 0.8$ \\
\hline \multirow{6}{*}{ M2 } & \multirow{6}{*}{ Martin et al., 2018} & LUX-4 & -21.0044 & -68.0177 & 4320 & 3.18 & $1.94 \pm 0.10$ & 3.0 & 0.98 & 0.99 & 10.0 & $15.0 \pm 0.7$ \\
\hline & & LUX-5 & -21.0043 & -68.0180 & 4383 & 3.18 & $2.42 \pm 0.11$ & 4.0 & 0.97 & 0.99 & 10.6 & $17.7 \pm 0.8$ \\
\hline & & LUX-13 & -21.0039 & -68.0194 & 4420 & 3.18 & $3.83 \pm 0.15$ & 2.0 & 0.98 & 0.99 & 11.2 & $26.2 \pm 1.1$ \\
\hline & & LUX-14 & -21.0039 & -68.0194 & 4420 & 3.18 & $2.48 \pm 0.10$ & 1.5 & 0.99 & 0.99 & 10.8 & $17.5 \pm 0.8$ \\
\hline & & LUX-15 & -21.0036 & -68.0200 & 4431 & 3.18 & $2.18 \pm 0.09$ & 3.0 & 0.98 & 0.99 & 10.6 & $15.8 \pm 0.7$ \\
\hline & & LUX-16 & -21.0038 & -68.0195 & 4415 & 3.18 & $2.31 \pm 0.09$ & 5.0 & 0.96 & 0.98 & 10.7 & $16.9 \pm 0.7$ \\
\hline \multirow{2}{*}{ M3 } & \multirow{2}{*}{ This Study } & LUX-11-12 & -21.0042 & -68.0194 & 4450 & 3.18 & $2.91 \pm 0.20$ & 3.0 & 0.98 & 0.95 & 11.3 & $20.8 \pm 1.4$ \\
\hline & & LUX-11-13 & -21.0042 & -68.0194 & 4454 & 3.18 & $2.69 \pm 0.12$ & 3.0 & 0.98 & 0.99 & 11.1 & $18.9 \pm 0.9$ \\
\hline Roches & \multirow{2}{*}{ This Study } & LUX-6 & -21.0044 & -68.0312 & 4676 & 3.18 & $2.19 \pm 0.12$ & 5.0 & 0.96 & 0.98 & 11.7 & $15.0 \pm 0.8$ \\
\hline Moutonnées & & LUX-7 & -21.0044 & -68.0312 & 4676 & 3.18 & $2.15 \pm 0.11$ & 5.0 & 0.96 & 0.98 & 11.7 & $14.8 \pm 0.7$ \\
\hline \multicolumn{13}{|c|}{ average value from Tunupa, Uturuncu and Sajama volcano } \\
\hline \multicolumn{13}{|c|}{${ }^{b} \mathrm{He}_{\mathrm{c}}=\mathrm{He}_{\text {tot }}-\mathrm{He}_{\mathrm{n}}-\mathrm{He}_{\mathrm{m}}$ (we considered $\mathrm{He}_{\mathrm{m}}=8.5 \times 10^{4}$ at. ${ }^{-1}$ for all samples) } \\
\hline \multicolumn{13}{|c|}{ 'Calculated with a density of $2.7 \mathrm{g.cm}{ }^{-3}$ and an attenuation length of $160 \mathrm{g.cm}{ }^{-2}$} \\
\hline \multicolumn{13}{|c|}{${ }^{d}$ Global scaling factor that accounts for the geomagnetic correction } \\
\hline \multicolumn{13}{|c|}{ e SLHL PR: weighted mean of the rates from Blard et al. (2013a) and Delunel et al. (2016) - Scaling scheme: Lal modified - Atmosphere: ERA40 - VDM: Muscheler et al. (2005) } \\
\hline
\end{tabular}




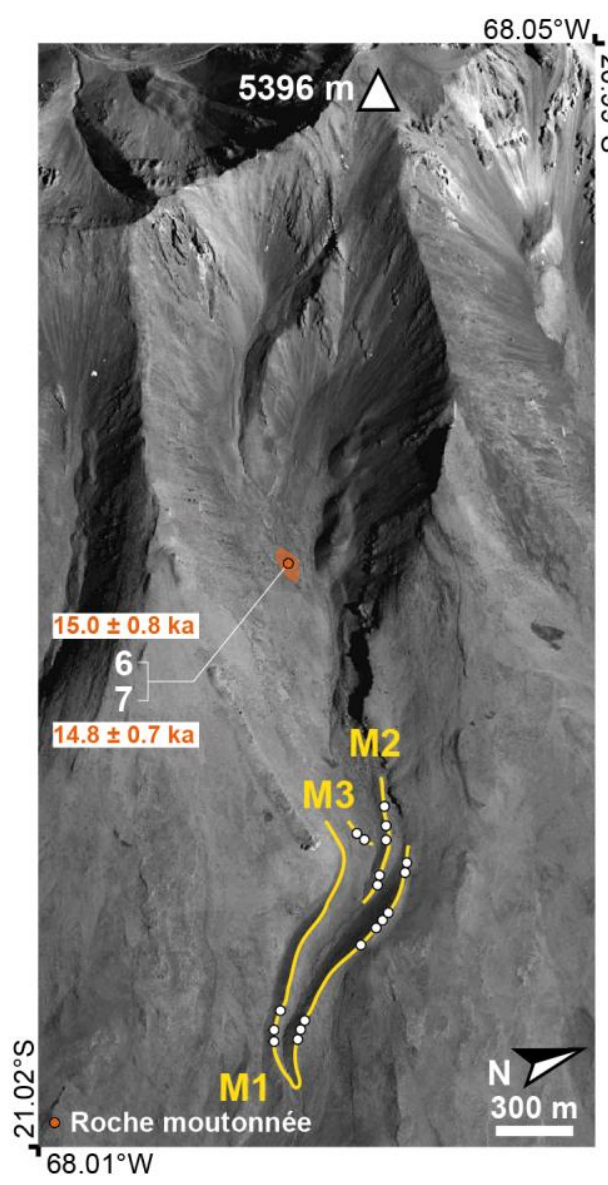

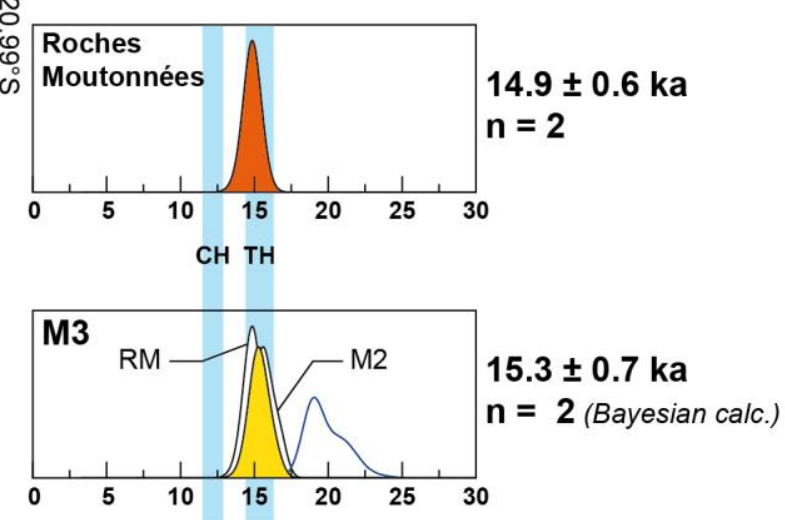
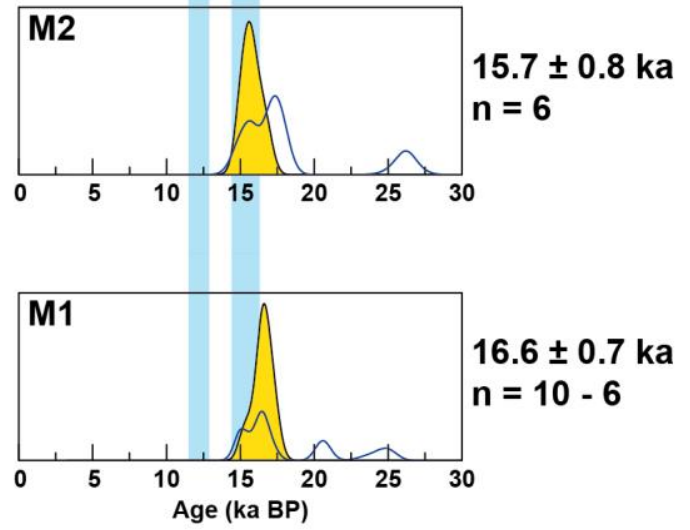

Figure 15. ${ }^{3} \mathrm{He}$ CRE ages on Cerro Luxar. Uncertainties are $1 \sigma$. The age PDFs are indicated for each moraine (yellow). Boulder ages contributing to the moraine PDFs beyond $30 \mathrm{ka}$ BP are not represented. Roche moutonnées and their age distributions are reported on the map in orange. The median age is reported for each PDF. ' $n$ ' indicates the number of samples; when $n$ is reported as ' $n=A-B$ ', $A$ is the total number of boulders dated on the moraine and $B$ is the number of boulders considered to be outliers. The blue curves are the raw PDFs before Bayesian processing, and the shaded histograms are the final $P D F$ from which ages were derived (see Section 3.1.5). Because the raw ages of M3 were not consistent with the youngest ages of the stratigraphically older moraines, the PDF of M3 was derived from those of M2 and the upper roches moutonnées (see Section 4.1.5). Blue bars labeled 'TH' and 'CH' indicate the Tauca and Coipasa highstands, respectively.

\subsection{ELA results}

The ELAs computed for each moraine are summarized in Table 7 and Figure 16. This figure also provides global context by comparing the ELA results with several other paleoclimatic proxies. All ELAs between the LGM and the Holocene range between 4,400 and 4,900 m asl. The paleo-ELA changes over the observed periods for Zongo Valley, Cerro Tunupa, and Nevado Sajama are approximately 400, 250, and $200 \mathrm{~m}$, respectively. Comparison between the four sites is, however, limited because the Tunupa and Luxar glacial records stop at around $13 \mathrm{ka} \mathrm{BP,} \mathrm{whereas} \mathrm{the} \mathrm{Zongo} \mathrm{and}$ Sajama glacial chronologies extend to the Early Holocene (11-10 ka BP). The well-represented 


\subsection{Paleoclimatic results}

773 the local temperature and precipitation associated with each moraine standstill. These results are 774 reported in Table 7 and plotted in Figures 16-18.

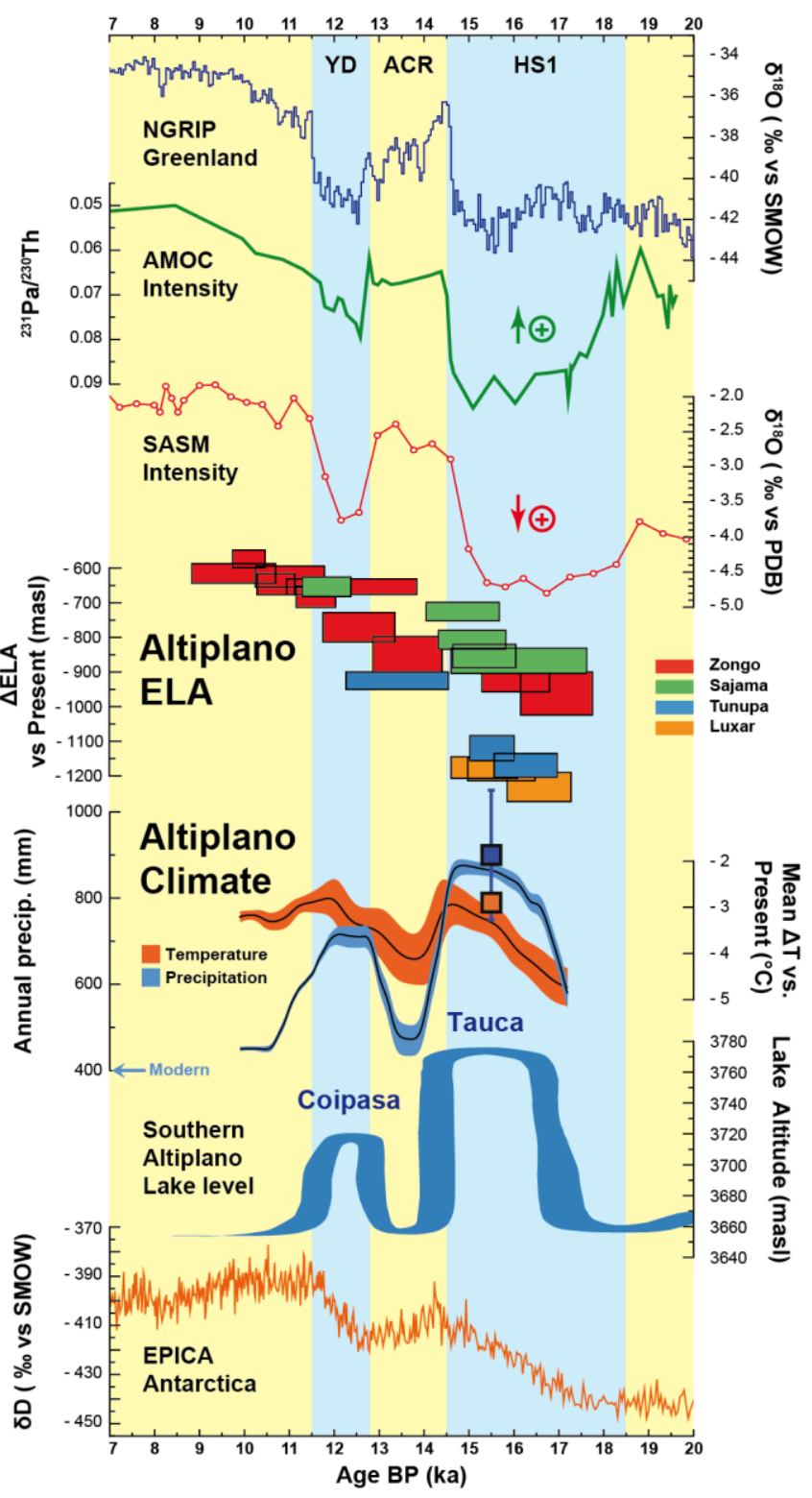

Figure 16. Late-glacial Altiplano ELA and regional precipitation and temperature compared to other late-glacial proxies for the 7-20 ka BP period. NGRIP: $\delta^{18} \mathrm{O}$ (\%o vs. SMOW) of the North Greenland ice core (Andersen et al., 2004). AMOC: ${ }^{231} \mathrm{~Pa}^{230}$ Th ratio in marine sediments (McManus et al., 2004). SASM: $\delta^{18} O$ (\%o vs. PDB) from Botuvera Cave speleothem carbonates, SE Brazil (Wang et al., 2007). Altiplano ELA: Paleo-ELAs computed in this study for the four studied sites, with $1 \sigma$ age uncertainties (box widths). Altiplano Climate: regional mean precipitation and temperature values derived from our reconstructions, including precipitation recycling (see Section 4.3.3). Lake level: Lake level reconstruction from shoreline dating in the southern basin of the Altiplano (Fig. 11). Data from Blard et al. (2011a), Placzek et al. (2006), Sylvestre et al. (1999), and the present study. EPICA: $\delta D$ (\%o vs. SMOW) from the EPICA Dome C ice core (Jouzel et al., 2007). 
The remarkable setting of the Altiplano watershed allows us to interpret the synchronous local

788 glacier and lake records and temporally reconstruct the local temperature for this region (Fig. 17).

789 Reconstructed temperature shifts during the late-glacial period (compared to present day conditions)

790 range from -5 to $-2.5^{\circ} \mathrm{C}$. The four sites show behaviors consistent with progressive warming from -5

791 to $-2.5^{\circ} \mathrm{C}$ during the Lake Tauca transgression and highstand, followed by colder conditions around -

$7924{ }^{\circ} \mathrm{C}$ between the two highstands and the progressive stabilization of the temperature shift at around -3

$793{ }^{\circ} \mathrm{C}$ at the onset of the Holocene. The uncertainties associated with these temperature reconstructions are 794 about $1^{\circ} \mathrm{C}(1 \sigma)$.

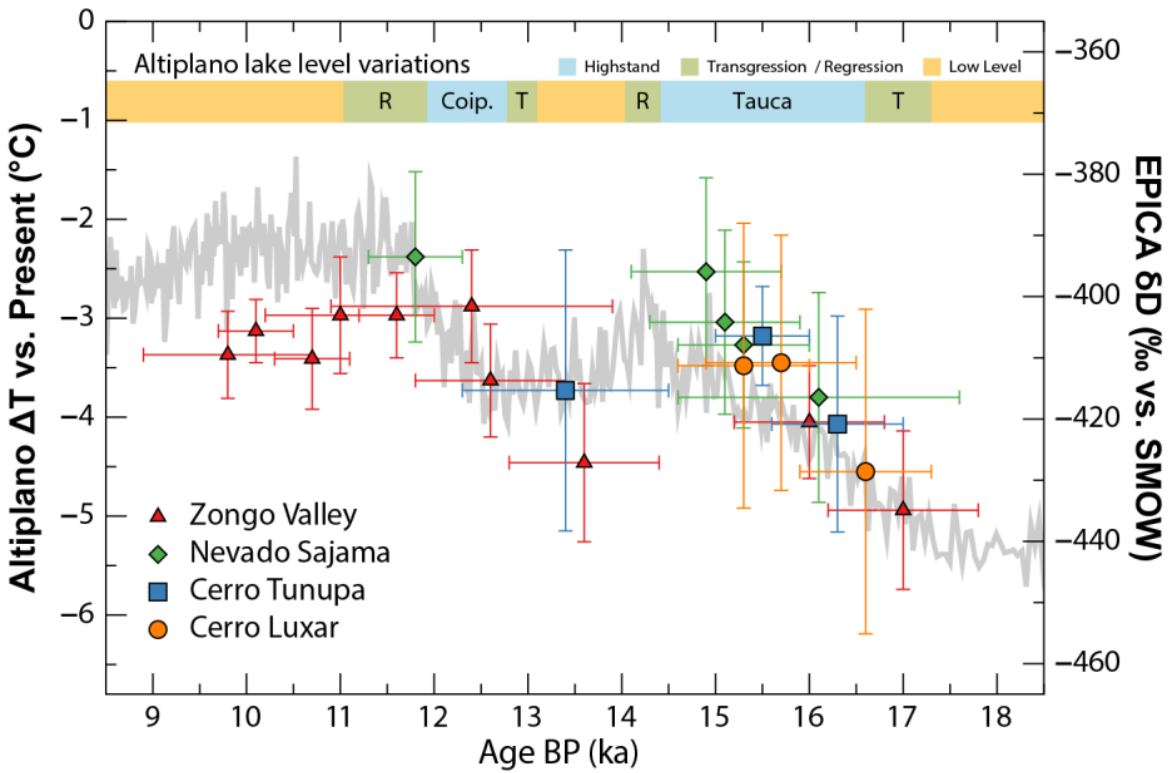

Figure 17. Late-glacial local temperature reconstruction inferred from our paleoglacier and paleolake inversion framework (see Section 3.3). Results are expressed relative to the present day mean annual temperature.

\subsubsection{Precipitation results at the glacial sites}

The reconstructed precipitation changes (reported here as the ratio $P_{\text {Paleo }} / P_{\text {Present }}$ ) at the four studied sites exhibit significantly different behaviors (Fig. 18). The most remarkable feature is the drastically increased precipitation ratio observed during the Tauca highstand for locations near the center of the paleolake. The rainfall ratio is close to 4 at Cerro Luxar and $>3$ at Cerro Tunupa, $\leq 2$ at the Zongo and Sajama sites. This trend is due to both (i) the strong north-south gradient in the present-day precipitation over the basin, which amplifies the relative precipitation increase when moisture advection 
over the basin increases, and (ii) the fact that these sites are too far from the lake to have been affected

807 by substantial rainfall amplification due to local water recycling. The higher ratio observed at Cerro

808 Luxar compared to Cerro Tunupa might appear counterintuitive because Cerro Luxar is near the 809 southwestern shoreline edge of the paleolakes, whereas Cerro Tunupa is in the center of the lake.

810 However, this feature directly results from the shape of the regional rainfall field.

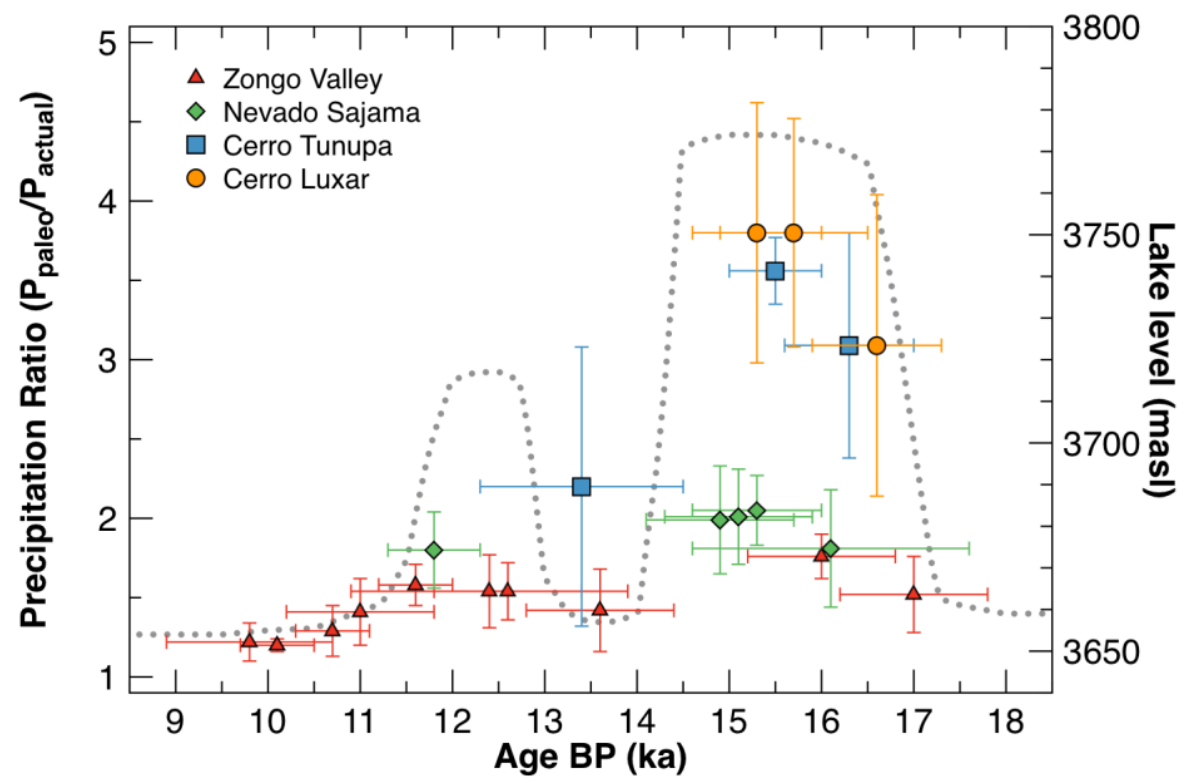

811

812

813

814

\subsubsection{Regional temperature and precipitation}

From the local temperature reconstruction presented in Figure 17, we calculated the mean regional temperature (relative to present-day temperature) and precipitation curves over the entire deglaciation (17-10 ka BP, both curves in Fig. 16). We derived the regional temperature curve by temporally averaging the individual moraine points from the four sites and accounting for their individual uncertainties. Using this mean regional temperature curve and its uncertainty envelope, we used the inversion algorithm (see Section 3.3) to reconstruct the precipitation field over the basin and derive the mean regional annual precipitation curve (Fig. 16). During the deglaciation, the regional temperature curve is characterized by a millennial variability. The mean $\Delta T$ value (relative to presentday) increases from -5 to $-2.5{ }^{\circ} \mathrm{C}$ between 17 and $14.5 \mathrm{ka} \mathrm{BP}$, then decreases to $-4.5{ }^{\circ} \mathrm{C}$ during the ACR, increases up to $-2.5^{\circ} \mathrm{C}$ during the Younger Dryas, and finally stabilizes around $-3{ }^{\circ} \mathrm{C}$ at the onset 
826 of the Holocene, between 11.5 and $10 \mathrm{ka} \mathrm{BP}$. The uncertainty associated with this signal remains around

$827 \pm 0.5^{\circ} \mathrm{C}$ during most of the deglaciation period. Precipitation follows similarly: the mean annual rainfall 828 increases from 530 to $960 \mathrm{~mm}$ during the Tauca transgression and highstand, then decreases to $510 \mathrm{~mm}$ 829 between the two highstands, reaches $690 \mathrm{~mm}$ during the Coipasa highstand, and finally stabilizes around $830450 \mathrm{~mm}$ at the onset of the Holocene. The uncertainty associated with this signal never exceeds \pm 25 831 mm during the study period.

\section{5. Discussion}

\subsection{Glacial chronologies}

\subsubsection{Zongo Valley}

The updated glacial chronology of Zongo Valley yields meaningful results. Only three of the 13

836 analyzed moraines show very high scatter: IP1, IP2, and MV. Given their location, IP1 and IP2 must be 837 older than $17 \mathrm{ka} \mathrm{BP}$, and they are not discussed further in this study. The Bayesian constraints brought by IP5 and CQ1 on MV enabled us to derive its age with an uncertainty better than 1 kyr. Other moraines

839 either present clear outliers (e.g. IP4) or relatively clustered ages. For these moraines, the Bayesian 840 filtering had only a marginal effect on the age distributions. The exceptions to these general observations 841 are the $\mathrm{T} 1$ and $\mathrm{T} 2$ Telata moraines that exhibit significant scatter; their age distributions were 842 importantly modified by the Bayesian constraints. Nonetheless, their ELAs are in good agreement with 843 those of the same age throughout the rest of the valley. IP3 and IP4 indicate that the local last glacial 844 maximum (LLGM) occurred before $17 \mathrm{ka}$ BP. The ELA changes remain limited between 17 and 13.5 845 ka BP in Zongo Valley $(\triangle \mathrm{ELA}<100 \mathrm{~m})$. A $10-\mathrm{km}$ horizontal retreat from IP5 to CQ4 subsequently 846 occurred over a 3-3.5 kyr interval, corresponding to an ELA rise of almost $300 \mathrm{~m}$. IP5 is coeval with 847 the ACR (14.5-12.9 ka BP) and CQ1 with the Younger Dryas (12.8-11.5 ka BP). The CQ3, CQ4, and 848 Telata moraines are concomitant with the Pleistocene-Holocene transition. 
Smith et al. (2009) used ${ }^{36} \mathrm{Cl}$ cosmogenic data to establish the first glacial chronology for

851 Nevado Sajama. In agreement with their results, our ${ }^{3} \mathrm{He}$ dataset confirms the presence of late-glacial 852 moraines on Nevado Sajama. However, the important scatter of their ${ }^{36} \mathrm{Cl}$ ages (possibly due to inter853 sample variability in $\mathrm{Cl}$ content; Schimmelpfennig et al., 2009) precludes a more detailed comparison 854 with our results.

Nevado Sajama records a major glacial advance around $16 \mathrm{ka}$ BP, coeval with the end of the transgression and the beginning of the Lake Tauca highstand. The ELA shift between 16 and $15 \mathrm{ka}$ BP

857 is less than $60 \mathrm{~m}$ ( $2 \mathrm{~km}$ of horizontal retreat), suggesting that climatic conditions remained relatively 858 stable during this period. The age of moraine M4 is coeval with the end of the Coipasa highstand, and 859 its corresponding ELA $(4,871 \mathrm{~m}$ asl $)$ is not significantly higher than that at the end of the Tauca 860 highstand as observed on moraine M3 $(\mathrm{ELA}=4,800 \mathrm{~m}$ asl). However, our results do not permit 861 evaluation of whether the Sajama glaciers receded above the M4 moraine front or remained stationary 862 between 15 and $12 \mathrm{ka}$ BP. A major glacial retreat probably occurred after the end of the Coipasa 863 highstand-Younger Dryas stadial.

\subsubsection{Cerro Tunupa}

Our recalculation does not substantially change the initial conclusions of Blard et al. (2009, 2013a). As they reported, the Tunupa moraines record a major glacial advance around $16.3 \mathrm{ka} \mathrm{BP}$ (M1), followed by the standstill that built moraine M2 synchronous to the Lake Tauca highstand-Heinrich 1 stadial $(15.5 \pm 0.5 \mathrm{ka} \mathrm{BP})$. Our ${ }^{3} \mathrm{He} \mathrm{CRE}$ ages of the upstream roches moutonnées confirm that this standstill was followed by a rather abrupt glacial retreat after $15 \mathrm{ka} \mathrm{BP}$ and an associated ELA shift of $200 \mathrm{~m}$ just before (or synchronous to, within uncertainties) the Lake Tauca regression at $14.5 \mathrm{ka} \mathrm{BP}$

871 (Fig. 14).

\subsubsection{Cerro Luxar}


standing between 4,700 and 4,750 $\mathrm{m}$ asl. Additionally, our ${ }^{3} \mathrm{He} \mathrm{CRE}$ ages of upstream roches

876 moutonnées indicate a rapid glacial retreat just after $15 \mathrm{ka} \mathrm{BP}$ and nearly synchronous to the Lake Tauca 877 regression (Fig. 15), as observed at Cerro Tunupa.

\subsubsection{Overview}

The Sajama, Tunupa, and Luxar moraines present rather similar glacial chronologies. They all record a major glacial standstills or re-advances around 16-15 ka BP coeval with the Tauca highstand. All three sites experienced a significant glacial retreat during the last centuries of the highstand or during the Lake Tauca regression. Tunupa and Luxar experienced the most significant ELA decrease, likely due to their proximity to the center of the paleolake. On Nevado Sajama, the ice tongue stabilized in the upper part of the valley during the Younger Dryas before later retreating.

Zongo Valley exhibits a slightly more complex pattern: although the Tauca moraine is also observed in this valley, the paleoglaciation there is characterized by a LLGM older than $17 \mathrm{ka} \mathrm{BP}$, and the persistence of climatic conditions similar to those during the LLGM until $13.5 \mathrm{ka}$ BP. The subsequent rapid and massive glacial retreat was followed by a marked standstill during the Younger Dryas and a progressive retreat during the Early Holocene. This geographic contrast between the paleoglacial behaviors of the Cordillera Real and the southeast Altiplano is consistent with the present day climatic setting of Andean glaciers (Sagredo and Lowell, 2012), probably due to the proximity of the Amazonian moisture source to Zongo Valley.

\subsection{Robustness of the paleoclimatic inversion}

\subsubsection{Uncertainties on reconstructed temperatures}

Our temperature reconstruction for the deglaciation period (Fig. 17) has an average uncertainty of $\pm 0.5^{\circ} \mathrm{C}$, which was propagated from all uncertainties arising from the parametrizations of the lake and glacier models. Some model parameters, such as AAR, are theoretically similar throughout a given valley, implying that the reported errors should be considered maximum values. Importantly, the temperature reconstructions for different sites yield similar and consistent values: the linear temperature increase between 17 and $15 \mathrm{ka} \mathrm{BP}$ (during the deglaciation) is defined by the paleoglacial records of 
901 each of the four glaciated valleys. Nearly synchronous temperatures are compatible within less than 0.5

$902{ }^{\circ} \mathrm{C}$, highlighting the regional consistency of our reconstruction. The cooling period during $14-13 \mathrm{ka} \mathrm{BP}$

903 is evidenced by two moraines from different glacial sites (Zongo and Tunupa) that yield consistent

904 temperature values. The final warming period during 13-11 ka BP is defined by several moraines of 905 Zongo Valley and one moraine on Nevado Sajama, all of which are compatible within uncertainties. In 906 summary, the trend in the temperature record is significant.

\subsubsection{The climatic conditions recorded by a moraine exposure age:}

908 significance, uncertainty and signal filtering

909 Traditionally, exposure ages of block sitting on top moraines are considered as documenting the 910 final episode of sediment piling and of moraine building, i.e. the final stage of a glacier advance or still

911 stand (Bennett, 2001). Even if uncertainties remain on the exact timing of block stabilization regarding 912 the glacier retreat after a glacier advance (Eichel et al., 2018), as well as on the CRN inheritance of a 913 block acquired during its final supraglacial period of transport (Briner et al., 2005; Heyman et al., 2011), 914 recent dating of Little Ice Age moraines in the Alps have shown that ${ }^{10} \mathrm{Be}$ exposure ages of blocks sitting 915 on moraines are nearly synchronous with the glacier advances documented by historical chronicles (e.g. 916 Schimmelpfennig et al., 2014). Such examples in the Alps suggests that this uncertainty might be lower 917 than $0.1 \mathrm{kyr}$, i.e. much lower than the uncertainties reported for the exposure ages in the present study 918 (0.5 to $1 \mathrm{kyr}$ ). The exact representativeness of CRN ages of boulders on moraine therefore probably has 919 little bearing on the interpretation of the moraine ages described in this study. Nevertheless, it should be 920 noted that the final uncertainty on the moraine ages, as well as the propagation of this uncertainty on the 921 paleolake level to calculate paleo-temperatures and paleoprecipitation, implies that the paleoclimatic 922 curves obtained are smoothed at the millennial scale and filtered from their high-frequency content. As 923 such, our paleoclimatic reconstructions based on moraines preclude discussion on high frequency 924 climate variation and abrupt transition at the centennial scale. 
Our reconstruction provides the first continuous records of absolute temperature and precipitation throughout the deglaciation period for the Altiplano. As such, our reconstructions can only punctually be compared to other regional studies. Blard et al. (2009) and Martin et al. (2018) focused on the Lake Tauca highstand (16-15 ka BP), whereas Placzek et al. (2013) established mean

931 precipitation and temperature records for three successive lake highstands: Lake Sajsi (24-20 ka BP), 932 Lake Tauca (16-15 ka BP), and Lake Coipasa (12 ka BP). Our temperature and precipitation records 933 for the Lake Tauca highstand are consistent with the $3{ }^{\circ} \mathrm{C}$ cooling and mean regional precipitation of $934900 \mathrm{~mm} \mathrm{yr}^{-1}\left(P_{\text {Tauca }} / P_{\text {Present }}=2.2\right)$ obtained by Martin et al. $(2018$; square symbols in Fig. 16$)$. However, 935 these paleoclimatic conditions differ from the cooler $\left(\Delta T_{\text {Tauca }} \approx-4\right.$ to $\left.-7{ }^{\circ} \mathrm{C}\right)$ and drier conditions $936\left(P_{\text {Tauca }} / P_{\text {Present }}<2\right)$ inferred by Blard et al. (2009) and Placzek et al. (2013) for the Lake Tauca highstand. 937 This discrepancy probably arises from the combination of three factors. First, our study uses an up-to938 date and more accurate approach to estimate the spatial distribution of precipitation. This new approach 939 is based on our recent work (Martin et al., 2018), and is more relevant than those of the pioneer studies 940 of Blard et al. (2009) and Placzek et al. (2013) because the spatial distribution of precipitation now 941 accounts for both the entire regional ELA variability and the distributed lake recycling anomaly 942 throughout the southern part of the catchment. Second, we used a different model to convert paleo-ELAs 943 into paleoclimatic variables $(P, T)$. Blard et al. (2009) applied a PDD model, which tends to overestimate

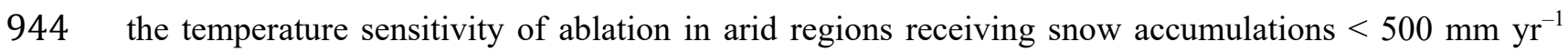
945 (Blard et al., 2011b; Sicart et al., 2008), whereas we used the robust empirical model of Condom et al. 946 (2007). Third, we used newer data to define the present-day climatic conditions: whereas Placzek et al. 947 (2013) considered a mean annual temperature of $10.8^{\circ} \mathrm{C}$ at $3,800 \mathrm{~m}$ asl for the entire Altiplano, our 948 compilation of present-day weather station data yielded spatially variable means from $\sim 6.3$ to $8.5^{\circ} \mathrm{C}$ at $9493,800 \mathrm{~m}$ asl (Table 1; Martin et al., 2018). Regarding the Early Holocene period (10-8 ka BP), Jomelli 950 et al. (2011) reported a cooling of $\sim 3{ }^{\circ} \mathrm{C}$ based on Cerro Telata moraines, which is similar to that derived 951 herein for the nearby Zongo Valley. Although they used a PDD model, the consistency with our results 
952 is likely due to the fact that this region is fed by abundant precipitation (annual snow accumulation >

$9531,000 \mathrm{~mm} \mathrm{a}^{-1}$ ). Indeed, under such wet conditions, PDD models yield an ELA-climate sensitivity similar 954 to that of the empirical model used here (Condom et al., 2007).

955 The glacier ice core $\delta^{18} \mathrm{O}$ records from Huascarán (Peru) and Sajama (Bolivia) have been used 956 to suggest that Andean temperatures during the deglaciation were similar to those in Greenland and the 957 North Atlantic, with HS-1 notably being the coldest period of the past $\sim 19$ ka BP (Thompson et al., 958 1995, 1998). However, other studies have argued that the O isotopic compositions of tropical ice cores 959 do not provide a pure temperature signal because they are also controlled by the composition of 960 precipitation and atmospheric processes (Ramirez et al., 2003). The $\delta^{18} \mathrm{O}$ signal in tropical ice may also 961 have been biased by vapor originating from Lakes Tauca and Coipasa, water sources with high $\delta^{18} \mathrm{O}$ 962 values (Quesada et al., 2015).

\subsection{Regional and global paleoclimatic implications}

Our reconstruction of both absolute precipitation and temperature during the last deglaciation represents a unique dataset documenting the regional and global paleoclimatic mechanisms affecting the southern Tropical Andes. Our new reconstructions reveal that (i) precipitation variability over the Altiplano reacted synchronously with the Greenland-Atlantic dynamic during the deglaciation

968 (Andersen et al., 2004; McManus et al., 2004), whereas (ii) temperatures were in phase with Antarctic 969 temperature fluctuations (Jouzel et al., 2007). These new observations are key in deciphering the 970 paleoclimatic connections between the Northern and Southern Hemispheres and the Tropics.

\subsubsection{Precipitation results} abrupt climatic oscillations of the Northern Hemisphere during the last deglaciation (Baker et al., 2001;

974 Blard et al., 2011a; Crivellari et al., 2018; Fritz et al., 2007; Gayo et al., 2012; Haug, 2001; Licciardi et 975 al., 2009; Martin et al., 2018; Placzek et al., 2006). However, until now, a continuous absolute record 976 of Altiplano paleoprecipitation during the last deglaciation was not available. Filling this gap, our 
reconstruction supports an interhemispheric connection between precipitation over the Altiplano,

978 temperatures in Greenland, and the Atlantic meridional overturning circulation (AMOC) during the

979 entire deglaciation (Fig. 16). However, our results do not allow us to extend this observation beyond the

980 Altiplano Basin to the entire tropical Andes.

981 Martin et al. (2018) reconstructed the spatial variability of precipitation at unprecedented resolution

982 during the Lake Tauca highstand (Heinrich 1 event) and suggested that atmospheric mechanisms

983 modulated the SASM, producing major precipitation changes over the Altiplano. Increases in

984 precipitation likely resulted from southward displacement and intensification of the Bolivian High (a

985 high-pressure cell), which enabled substantial westward moisture advection towards the Altiplano

986 Basin. A continental forcing of this phenomenon might be fluctuations of the South Atlantic 987 Convergence Zone (SACZ), which controls the position and intensity of the Bolivian High (Lenters and 988 Cook, 1999) and showed extreme fluctuations during the Tauca highstand ("Mega-SACZ" events;

989 Stríkis et al., 2015). Similar events can be invoked to explain the abundant precipitation during the 990 Coipasa highstand.

991 The mechanisms linking changes of the SASM to the global climate remain debated. Additional 992 reconstructions of continental precipitation during the last deglaciation based on inverse glacier 993 modeling could contribute to better identifying the controlling atmospheric patterns. However, the 994 southward migration of synoptic atmospheric features during cold periods in the North Atlantic has been 995 repeatedly observed or modeled for the Northern Westerlies (Roe and Lindzen, 2001; Zhang et al., 996 2014), the Intertropical Convergence Zone (Crivellari et al., 2018; Kanner et al., 2012; Peterson, 2000), 997 and the Southern Westerlies (Anderson et al., 2009; Denton et al., 2010; Toggweiler et al., 2006).

\subsubsection{Temperature results}

Only a few empirical studies have suggested common Antarctic and Tropical atmospheric temperature patterns. The meta-analysis of Tropical Andean moraine ages by Jomelli et al. (2014) showed that most Tropical Andean glaciers had a greater extent during the ACR than during the Younger

1002 Dryas. They also used a transient general circulation model (GCM) simulation to show that the 1003 connection between Southern Hemispheric and Tropical temperatures results from a combination of 
1004 several atmospheric mechanisms, including AMOC modulation, $\mathrm{CO}_{2}$ level, precipitation, vegetation, 1005 and local heat budgets. However, Groot et al. (2011) presented a contradictory paleotemperature dataset; 1006 based on a continuous 284-kyr-long pollinic record from a core drilled in Lake Fúquene, Columbia $1007\left(5^{\circ} \mathrm{N}, 2,540 \mathrm{~m}\right.$ asl $)$, they asserted that temperature fluctuations in Columbia follow North Atlantic1008 Greenland fluctuations on glacial-interglacial time scales. In this context, our results show that an Antarctic-like temperature pattern characterized the high 1010 Andes, at least as far north as $15^{\circ} \mathrm{S}$, during the last deglaciation, with a linear warming trend of $\sim 2.5^{\circ} \mathrm{C}$ 1011 during $17-14.5 \mathrm{ka} \mathrm{BP}$, a return to conditions $\sim 1.5^{\circ} \mathrm{C}$ colder during the $\mathrm{ACR}(14.5-13 \mathrm{ka} \mathrm{BP})$, a second 1012 warming of $\sim 1.5$ to $2{ }^{\circ} \mathrm{C}$ during $13-12 \mathrm{ka} \mathrm{BP}$, and a subsequent stabilization of temperatures during the 1013 early Holocene (Fig. 17). This trend is remarkably consistent with temperature variations in Antarctica 1014 over the same period, as recorded by the $\mathrm{H}$ isotopic composition of ice cores (Fig. 17). This correlation suggests a homogeneous, large-scale temperature evolution in the Southern Hemisphere, i.e. from the 1016 southernmost latitudes to the southern Tropical Andes, during the last deglaciation. This similarity 1017 between tropical and Antarctic temperatures may also result from a common response of both regions 1018 to independent, but synchronous, forcings. Barker et al. (2011) established that temperature variations 1019 in the Antarctic and Southern Ocean regions are partially controlled by the bipolar seesaw, and thus, by 1020 AMOC fluctuations. Moreover, at seasonal to inter-annual time scales, the southerly flow of Antarctic 1021 glacial air masses is thought to control significant cooling in the southern and mid-latitude Andes 1022 (Schneider et al., 2003). If the frequency of such airflow intrusions increased and persisted over 1023 millennial timescales, it could explain the Antarctic-like temperature pattern of the Altiplano as 1024 observed herein.

1025 However, the temperature pattern of the Altiplano observed during the last deglaciation could 1026 also reflect a regional response to variations in regional precipitation via their impact on the energy 1027 budget. This could explain the positive correlation between precipitation and temperature over the 1028 Altiplano, with the warmest periods being associated with the wettest events (Fig. 16). Further studies 1029 employing high-resolution GCM simulations over that Late Pleistocene-Holocene transition will be key 1030 to disentangling these various scenarios. 
An important methodological conclusion that can be drawn from our paleoclimatic

1033 reconstruction is that paleoglacial fluctuations may not simply be a proxy for temperature that can be

1034 directly used to infer large-scale paleoclimatic changes. In dry regions where glacial mass balances are 1035 under a precipitation-limited regime, such a simplification may yield inaccurate conclusions. For 1036 example, our data show that, despite atmospheric warming during the last deglaciation (17-15 ka BP), 1037 Altiplano glaciers advanced due to increased precipitation concomitant with the Lake Tauca highstand 1038 (Fig. 18). Although temperature is the main control of glacier dynamics, substantial precipitation 1039 variations modulate glacial advances and retreats, and can counterbalance or even surpass the effects of 1040 slight warming. For example, according to equation (2), a precipitation increase of 1000 to $1600 \mathrm{~mm} . \mathrm{yr}^{-}$

$1041{ }^{1}$ can compensate a $2^{\circ} \mathrm{C}$ warming. Such glacier fluctuations regionally driven by precipitations might 1042 appear as a rather counter intuitive result. According to this mechanism, local moisture increase during 1043 the YD may have triggered glacier readvances that have erased the moraines left by the former and 1044 colder period of the ACR.

1045 Such obliteration could be of limited spatial extent, and could have occurred in areas affected by a 1046 marked local increase in precipitation, such as promoted by moisture recycling in the vicinity of a large 1047 lake. This might explain why preserved ACR moraines are less prevalent in the central Altiplano than 1048 in other regions of the wet Tropical Andes (Jomelli et al., 2014). Therefore, the potential importance of 1049 the respective roles of precipitation and temperature should be carefully considered in future 1050 paleoclimatic studies relying on paleo-ELA reconstructions, ideally by coupling the interpretation of 1051 paleo-ELA inventories with independent proxies of precipitation and temperature. 


\section{Concluding remarks}

In Zongo Valley, the oldest glacial extent for which geochronological constraints are available

1054 ( $\geq 17 \mathrm{ka} \mathrm{BP}$ ) was approximately maintained until $13.5 \mathrm{ka} \mathrm{BP}$, and was followed by a massive glacial retreat until the early Holocene. This retreat was associated with an ELA variation of $300 \mathrm{~m}$. Nevado Sajama, Cerro Tunupa, and Cerro Luxar exhibit moraines synchronous with the Tauca Lake highstand (c. $16 \mathrm{ka} \mathrm{BP}$ ), followed by different retreat timings. For these three sites, the ELA rose by $\sim 200 \mathrm{~m}$ after the end of the Tauca highstand.

At the scale of individual glacial sites, our precipitation reconstruction is characterized by a

1060 strong spatial variability during the Tauca highstand due to lake-enhanced precipitation. At the regional

1061 scale, precipitation variations over the Altiplano basin were paced by the Northern Hemispheric dynamic, with the wettest period on the Altiplano being synchronous to the cold HS1a and Younger Dryas events. Our regional temperature reconstruction shows good consistency with Antarctic temperatures: the temperature curve (relative to present-day temperatures) defines (i) a linear warming 1065 trend from -5 to $-2.5{ }^{\circ} \mathrm{C}$ during $17-14.5 \mathrm{ka} \mathrm{BP}$, (ii) a return to colder conditions $\left(-4{ }^{\circ} \mathrm{C}\right)$ during $14.5-$ $106613 \mathrm{ka} \mathrm{BP}$, (iii) a second warming after $13 \mathrm{ka} \mathrm{BP}$ (to $-3{ }^{\circ} \mathrm{C}$ ), followed by (iv) the stabilization of 1067 temperatures into the Early Holocene.

Because the conditions within the Altiplano basin were sufficiently cold for glacial settlement and growth, glacial dynamics were driven by the regional precipitation increase during the Lake Tauca and Lake Coipasa highstands, which explains the abundance of morainic records synchronous with the

1071 Tauca highstand despite warming temperatures. Outside of these periods, glaciers were driven by large1072 scale temperature variations. Our results provide an original framework for understanding why the ACR 1073 is more represented than the Younger Dryas among morainic records throughout the Tropical Andes, 1074 and why North Atlantic cooling events (coeval with Altiplano lake highstands), that enhanced local precipitation, correspond to glacial advances over the Altiplano basin. These results exemplify that paleoglacial variations cannot solely be interpreted in terms of temperature variations, and that regional precipitation patterns can significantly affect glacial dynamics. 


\section{Acknowledgments}

This work was funded by the INSU EVE-LEFE program and the ANR Jeunes Chercheurs

1080 GALAC project (ANR-11-JS56-011-01). We greatly appreciated the logistical support of the Institut de 1081 Recherche pour le Développement (IRD) of La Paz (Bolivia) during our field trips between 2010 and 2013. The ASTER French national AMS facility (CEREGE, Aix-en-Provence) is supported by INSU/CNRS, the ANR through the "Equipements d'Excellence" program, IRD, and CEA. Field measurements of mass balance and ELA on Bolivian and Ecuadorian glaciers were provided by the Andean part of the Service National d'Observation GLACIOCLIM, funded by the French IRD, the Universidad Mayor de San Andres (IGEMA, IHH) in Bolivia and the Insituto Nacional de Meteorologia e Hidrologiain Ecuador.

We warmly thank C. Hautefeuille and Benj Barry for their contributions to the Luxar datings, devices during analytic sessions, V. Mariotti and M. Prémaillon for their help during field trips and sample collection, Flo Gallo, M. Protin, and D. Brunstein for their support during ${ }^{10}$ Be chemical analyses, and L. Tissandier and Y. Marrocchi for help with SEM and mineral analyses. We are grateful manuscript clarity.

\section{References}

Aceituno, P., 1996. Elementos del clima en el Altiplano Sudamericano. Rev. Geofis. 44, 37-55.

\section{Ammann, C., Jenny, B., Kammer, K., Messerli, B., 2001. Late Quaternary Glacier response to humidity changes in the arid} Andes of Chile (18-29º S). Palaeogeogr. Palaeoclimatol. Palaeoecol. 172, 313-326. https://doi.org/10.1016/S00310182(01)00306-6

Andersen, K.K., Azuma, N., Barnola, J.-M.J.-M., Bigler, M., Biscaye, P., Caillon, N., Chappellaz, J., Clausen, H.B., DahlJensen, D., Fischer, H., Flückiger, J., Fritzsche, D., Fujii, Y., Goto-Azuma, K., Grønvold, K., Gundestrup, N.S., Hansson, M., Huber, C., Hvidberg, C.S., Johnsen, S.J., Jonsell, U., Jouzel, J., Kipfstuhl, S., Landais, A., Leuenberger, M., Lorrain, R., Masson-Delmotte, V., Miller, H., Motoyama, H., Narita, H., Popp, T., Rasmussen, S.O., Raynaud, D. Rothlisberger, R., Ruth, U., Samyn, D., Schwander, J., Shoji, H., Siggard-Andersen, M.-L.M.-L., Steffensen, J.P., Stocker, T., Sveinbjörnsdóttir, A.E., Svensson, A., Takata, M., Tison, J.-L.J.-L., Thorsteinsson, T., Watanabe, O., Wilhelms, F., White, J.W.C., 2004. High-resolution record of Northern Hemisphere climate extending into the last interglacial period. Nature 431, 147-51. https://doi.org/10.1038/nature02805 
Anderson, R.F., Ali, S., Bradtmiller, L.I., Nielsen, S.H.H., Fleisher, M.Q., Anderson, B.E., Burckle, L.H., 2009. WindDriven Upwelling in the Southern Ocean and the Deglacial Rise in Atmospheric CO2. Science. 323, 1443-1448. https://doi.org/10.1126/science.1167441

Andrews, J.N., 1985. The isotopic composition of radiogenic helium and its use to study groundwater movement in confined aquifers. Chem. Geol. 49, 339-351. https://doi.org/10.1016/0009-2541(85)90166-4

Andrews, J.N., Kay, R.L.F., 1982. Natural production of tritium in permeable rocks. Nature 298, 361-363. https://doi.org/10.1038/298361a0

Argollo, J., Mourguiart, P., 2000. Late Quaternary climate history of the Bolivian Altiplano. Quat. Int. 72, $37-51$. https://doi.org/10.1016/S1040-6182(00)00019-7

Baker, P. a, Seltzer, G.O., Fritz, S.C., Dunbar, R.B., Grove, M.J., Tapia, P.M., Cross, S.L., Rowe, H.D., Broda, J.P., 2001. The history of South American tropical precipitation for the past 25,000 years. Science 291, 640-3. https://doi.org/10.1126/science.291.5504.640

Balco, G., Stone, J.O., Lifton, N. a., Dunai, T.J., 2008. A complete and easily accessible means of calculating surface exposure ages or erosion rates from 10Be and 26Al measurements. Quat. Geochronol. 3, 174-195. https://doi.org/10.1016/j.quageo.2007.12.001

Barker, S., Diz, P., Vautravers, M.J., Pike, J., Knorr, G., Hall, I.R., Broecker, W.S., 2009. Interhemispheric Atlantic seesaw response during the last deglaciation. Nature 457, 1097-1102. https://doi.org/10.1038/nature07770

Barker, S., Knorr, G., Edwards, R.L., Parrenin, F., Putnam, A.E., Skinner, L.C., Wolff, E., Ziegler, M., 2011. 800,000 Years of Abrupt Climate Variability. Science 334, 347-51. https://doi.org/10.1126/science. 1203580

Benn, D.I., Lehmkuhl, F., 2000. Mass balance and equilibrium-line altitudes of glaciers in high-mountain environments. Quat. Int. 65-66, 15-29. https://doi.org/10.1016/S1040-6182(99)00034-8

Benn, D.I., Owen, L.A., Osmaston, H.A., Seltzer, G.O., Porter, S.C., Mark, B., 2005. Reconstruction of equilibrium-line altitudes for tropical and sub-tropical glaciers. Quat. Int. 138-139, 8-21. https://doi.org/10.1016/j.quaint.2005.02.003

Bennett, M.R., 2001. The morphology, structural evolution and significance of push moraines. Earth-Science Rev. 53, 197236. https://doi.org/10.1016/S0012-8252(00)00039-8

Blard, P.-H., Balco, G., Burnard, P.G., Farley, K.A., Fenton, C.R., Friedrich, R., Jull, A.J.T., Niedermann, S., Pik, R., Schaefer, J.M., Scott, E.M., Shuster, D.L., Stuart, F.M., Stute, M., Tibari, B., Winckler, G., Zimmermann, L., 2015. An inter-laboratory comparison of cosmogenic $3 \mathrm{He}$ and radiogenic $4 \mathrm{He}$ in the CRONUS-P pyroxene standard. Quat. Geochronol. 26, 11-19. https://doi.org/10.1016/j.quageo.2014.08.004

Blard, P.-H., Braucher, R., Lavé, J., Bourlès, D., 2013a. Cosmogenic 10Be production rate calibrated against $3 \mathrm{He}$ in the high Tropical Andes (3800-4900 m, 20-22 ${ }^{\circ}$ S). Earth Planet. Sci. Lett. 382, 140-149. https://doi.org/10.1016/j.epsl.2013.09.010

Blard, P.-H., Lavé, J., Farley, K. a., Fornari, M., Jiménez, N., Ramirez, V., 2009. Late local glacial maximum in the Central Altiplano triggered by cold and locally-wet conditions during the paleolake Tauca episode (17-15ka, Heinrich 1). Quat. Sci. Rev. 28, 3414-3427. https://doi.org/10.1016/j.quascirev.2009.09.025

Blard, P.-H., Lave, J., Farley, K. a., Ramirez, V., Jimenez, N., Martin, L.C.P., Charreau, J., Tibari, B., Fornari, M., 2014. Progressive glacial retreat in the Southern Altiplano (Uturuncu volcano, $22^{\circ} \mathrm{S}$ ) between 65 and 14 ka constrained by cosmogenic 3He dating. Quat. Res. 82, 209-221. https://doi.org/10.1016/j.yqres.2014.02.002

Blard, P.-H., Lavé, J., Sylvestre, F., Placzek, C.J., Claude, C., Galy, V., Condom, T., Tibari, B., 2013b. Cosmogenic 3He production rate in the high tropical Andes $\left(3800 \mathrm{~m}, 20^{\circ} \mathrm{S}\right)$ : Implications for the local last glacial maximum. Earth Planet. Sci. Lett. 377-378, 260-275. https://doi.org/10.1016/j.epsl.2013.07.006

Blard, P.-H., Sylvestre, F., Tripati, A.K., Claude, C., Causse, C., Coudrain, A., Condom, T., Seidel, J.-L., Vimeux, F., Moreau, C., Dumoulin, J.-P., Lavé, J., 2011a. Lake highstands on the Altiplano (Tropical Andes) contemporaneous with Heinrich 1 and the Younger Dryas: new insights from $14 \mathrm{C}, \mathrm{U}-\mathrm{Th}$ dating and $\delta 18 \mathrm{O}$ of carbonates. Quat. Sci. Rev. 30, 3973-3989. https://doi.org/10.1016/j.quascirev.2011.11.001

Blard, P.-H., Wagnon, P., Lavé, J., Soruco, A., Sicart, J.-E., Francou, B., 2011b. Degree-day melt models for paleoclimate reconstruction from tropical glaciers: calibration from mass balance and meteorological data of the Zongo glacier (Bolivia, 16 S). Clim. Past Discuss. 7, 2119-2158. https://doi.org/10.5194/cpd-7-2119-2011

Briner, J.P., Kaufman, D.S., Manley, W.F., Finkel, R.C., Caffee, M.W., 2005. Cosmogenic exposure dating of late Pleistocene moraine stabilization in Alaska. Geol. Soc. Am. Bull. 117, 1108. https://doi.org/10.1130/B25649.1

Broecker, W., Putnam, A.E., 2012. How did the hydrologic cycle respond to the two-phase mystery interval? Quat. Sci. Rev. 57, 17-25. https://doi.org/10.1016/j.quascirev.2012.09.024

Broecker, W.S., 1998. Paleocean circulation during the Last Deglaciation: A bipolar seesaw? Paleoceanography 13, 119. https://doi.org/10.1029/97PA03707

Bromley, G.R.M., Schaefer, J.M., Hall, B.L., Rademaker, K.M., Putnam, A.E., Todd, C.E., Hegland, M., Winckler, G., Jackson, M.S., Strand, P.D., 2016. A cosmogenic 10 Be chronology for the local last glacial maximum and termination in the Cordillera Oriental, southern Peruvian Andes: Implications for the tropical role in global climate. Quat. Sci. Rev. 148, 54-67. https://doi.org/10.1016/j.quascirev.2016.07.010

Carcaillet, J., Angel, I., Carrillo, E., Audemard, F. a., Beck, C., 2013. Timing of the last deglaciation in the Sierra Nevada of the Mérida Andes, Venezuela. Quat. Res. 80, 482-494. https://doi.org/10.1016/j.yqres.2013.08.001

Clayton, J.D., Clapperton, C.M., 1997. Broad synchrony of a Late-glacial glacier advance and the highstand of palaeolake Tauca in the Bolivian Altiplano. J. Quat. Sci. 12, 169-182. https://doi.org/10.1002/(SICI)10991417(199705/06)12:3<169::AID-JQS304>3.0.CO;2-S

Condom, T., 2002. Dynamiques d'extension lacustre et glaciaire associées aux modifications du climat dans les Andes Centrales. Université Paris VI, France.

Condom, T., Coudrain, A., Dezetter, A., Brunstein, D., Delclaux, F., Jean-Emmanuel, S., 2004. Transient modelling of lacustrine regressions: two case studies from the Andean Altiplano. Hydrol. Process. 18, 2395-2408. 
Condom, T., Coudrain, A., Sicart, J.E., Théry, S., 2007. Computation of the space and time evolution of equilibrium-line altitudes on Andean glaciers $\left(10^{\circ} \mathrm{N}-55^{\circ} \mathrm{S}\right)$. Glob. Planet. Change 59, 189-202. https://doi.org/10.1016/j.gloplacha.2006.11.021

Crivellari, S., Chiessi, C.M., Kuhnert, H., Häggi, C., da Costa Portilho-Ramos, R., Zeng, J.-Y., Zhang, Y., Schefuß, E., Mollenhauer, G., Hefter, J., Alexandre, F., Sampaio, G., Mulitza, S., 2018. Increased Amazon freshwater discharge during late Heinrich Stadial 1. Quat. Sci. Rev. 181, 144-155. https://doi.org/10.1016/j.quascirev.2017.12.005

Cruz, F.W., Burns, S.J., Karmann, I., Sharp, W.D., Vuille, M., Cardoso, A.O., Ferrari, J.A., Silva Dias, P.L., Viana, O., 2005. Insolation-driven changes in atmospheric circulation over the past 116,000 years in subtropical Brazil. Nature $434,63-$ 66. https://doi.org/10.1038/nature03365

Dee, D.P., Uppala, S.M., Simmons, A.J., Berrisford, P., Poli, P., Kobayashi, S., Andrae, U., Balmaseda, M.A., Balsamo, G., Bauer, P., Bechtold, P., Beljaars, A.C.M., van de Berg, L., Bidlot, J., Bormann, N., Delsol, C., Dragani, R., Fuentes, M., Geer, A.J., Haimberger, L., Healy, S.B., Hersbach, H., Hólm, E. V., Isaksen, L., Kållberg, P., Köhler, M., Matricardi, M., McNally, A.P., Monge-Sanz, B.M., Morcrette, J.-J., Park, B.-K., Peubey, C., de Rosnay, P., Tavolato, C., Thépaut, J.-N., Vitart, F., 2011. The ERA-Interim reanalysis: configuration and performance of the data assimilation system. Q. J. R. Meteorol. Soc. 137, 553-597. https://doi.org/10.1002/qj.828

Delunel, R., Blard, P.-H., Martin, L.C.P., Nomade, S., Schlunegger, F., 2016. Long term low latitude and high elevation cosmogenic $3 \mathrm{He}$ production rate inferred from a $107 \mathrm{ka}$-old lava flow in northern Chile; $22^{\circ} \mathrm{S}-3400 \mathrm{ma}$. .1 . Geochim. Cosmochim. Acta 184, 71-87. https://doi.org/10.1016/j.gca.2016.04.023

Denton, G.H., Anderson, R.F., Toggweiler, J.R., Edwards, R.L., Schaefer, J.M., Putnam, A.E., 2010. The Last Glacial Termination. Science (80-. ). 328, 1652-1656. https://doi.org/10.1126/science.1184119

Eichel, J., Draebing, D., Meyer, N., 2018. From active to stable: Paraglacial transition of Alpine lateral moraine slopes. L. Degrad. Dev. 29, 4158-4172. https://doi.org/10.1002/1dr.3140

Farber, D.L., Hancock, G.S., Finkel, R.C., Rodbell, D.T., 2005. The age and extent of tropical alpine glaciation in the Cordillera Blanca, Peru. J. Quat. Sci. 20, 759-776. https://doi.org/10.1002/jqs.994

Fox, A.N., 1993. Snowline altitude and climate at present and during the Last Pleistocene Glacial Maximum in the Central Andes $\left(5^{\circ}-28^{\circ} \mathrm{S}\right)$. Cornell University.

Fritz, S.C., Baker, P.A., Seltzer, G.O., Ballantyne, A., Tapia, P., Cheng, H., Edwards, R.L., 2007. Quaternary glaciation and hydrologic variation in the South American tropics as reconstructed from the Lake Titicaca drilling project. Quat. Res. 68, 410-420. https://doi.org/10.1016/j.yqres.2007.07.008

Garreaud, R., Vuille, M., Clement, A.C., 2003. The climate of the Altiplano: observed current conditions and mechanisms of past changes. Palaeogeogr. Palaeoclimatol. Palaeoecol. 194, 5-22. https://doi.org/10.1016/S0031-0182(03)00269-4

Garreaud, R.D., Vuille, M., Compagnucci, R., Marengo, J., 2009. Present-day South American climate. Palaeogeogr. Palaeoclimatol. Palaeoecol. 281, 180-195. https://doi.org/10.1016/j.palaeo.2007.10.032

Gayo, E.M., Latorre, C., Jordan, T.E., Nester, P.L., Estay, S.A., Ojeda, K.F., Santoro, C.M., 2012. Late Quaternary hydrological and ecological changes in the hyperarid core of the northern Atacama Desert $\left(221^{\circ} \mathrm{S}\right)$. Earth-Science Rev. 113, 120-140. https://doi.org/10.1016/j.earscirev.2012.04.003

Groot, M.H.M., Bogotá, R.G., Lourens, L.J., Hooghiemstra, H., Vriend, M., Berrio, J.C., Tuenter, E., Van der Plicht, J., Van Geel, B., Ziegler, M., Weber, S.L., Betancourt, A., Contreras, L., Gaviria, S., Giraldo, C., González, N., Jansen, J.H.F., Konert, M., Ortega, D., Rangel, O., Sarmiento, G., Vandenberghe, J., Van der Hammen, T., Van der Linden, M., Westerhoff, W., 2011. Ultra-high resolution pollen record from the northern Andes reveals rapid shifts in montane climates within the last two glacial cycles. Clim. Past 7, 299-316. https://doi.org/10.5194/cp-7-299-2011

Hastenrath, S., 1991. Climate Dynamics of the Tropics. Springer Netherlands, Dordrecht. https://doi.org/10.1007/978-94011-3156-8

Haug, G.H., 2001. Southward Migration of the Intertropical Convergence Zone Through the Holocene. Science (80-. ). 293, 1304-1308. https://doi.org/10.1126/science. 1059725

Heyman, J., Stroeven, A.P., Harbor, J.M., Caffee, M.W., 2011. Too young or too old: Evaluating cosmogenic exposure dating based on an analysis of compiled boulder exposure ages. Earth Planet. Sci. Lett. 302, 71-80. https://doi.org/10.1016/j.epsl.2010.11.040

Jackson, M.S., Kelly, M.A., Russell, J.M., Doughty, A.M., Howley, J.A., Chipman, J.W., Cavagnaro, D., Nakileza, B., Zimmerman, S.R.H., 2019. High-latitude warming initiated the onset of the last deglaciation in the tropics. Sci. Adv. 5, eaaw2610. https://doi.org/10.1126/sciadv.aaw2610

Jomelli, V., Favier, V., He, F., Liu, Z., 2016. High altitude temperature changes in the tropical Andes over the last 15000 years estimated from a glaciological model. Glaciers Form. Clim. Chang. their Eff. Nov. Sci. Publ. New York.

Jomelli, V., Favier, V., Vuille, M., Braucher, R., Martin, L., Blard, P.-H.P.-H., Colose, C., Brunstein, D., He, F., Khodri, M., Bourlès, D.L.L., Leanni, L., Rinterknecht, V., Grancher, D., Francou, B., Ceballos, J.L.L., Fonseca, H., Liu, Z., OttoBliesner, B.L.L., 2014. A major advance of tropical Andean glaciers during the Antarctic cold reversal. Nature 513, 224-228. https://doi.org/10.1038/nature13546

Jomelli, V., Khodri, M., Favier, V., Brunstein, D., Ledru, M.-P., Wagnon, P., Blard, P.-H., Sicart, J.-E., Braucher, R., Grancher, D., Bourlès, D.L., Braconnot, P., Vuille, M., 2011. Irregular tropical glacier retreat over the Holocene epoch driven by progressive warming. Nature 474, 196-9. https://doi.org/10.1038/nature10150

Jouzel, J., Masson-Delmotte, V., Cattani, O., Dreyfus, G., Falourd, S., Hoffmann, G., Minster, B., Nouet, J., Barnola, J.M., Chappellaz, J., Fischer, H., Gallet, J.C., Johnsen, S., Leuenberger, M., Loulergue, L., Luethi, D., Oerter, H., Parrenin, F., Raisbeck, G., Raynaud, D., Schilt, A., Schwander, J., Selmo, E., Souchez, R., Spahni, R., Stauffer, B., Steffensen, J.P., Stenni, B., Stocker, T.F., Tison, J.L., Werner, M., Wolff, E.W., 2007. Orbital and Millennial Antarctic Climate Variability over the Past 800,000 Years. Science (80-. ). 317, 793-796. https://doi.org/10.1126/science.1141038

Kanner, L.C., Burns, S.J., Cheng, H., Edwards, R.L., 2012. High-Latitude Forcing of the South American Summer Monsoon 
During the Last Glacial. Science (80-. ). 335, 570-573. https://doi.org/10.1126/science.1213397

Kelly, M. a., Lowell, T. V., Applegate, P.J., Phillips, F.M., Schaefer, J.M., Smith, C. a., Kim, H., Leonard, K.C., Hudson, A.M., 2015. A locally calibrated, late glacial $10 \mathrm{Be}$ production rate from a low-latitude, high-altitude site in the Peruvian Andes. Quat. Geochronol. 26, 70-85. https://doi.org/10.1016/j.quageo.2013.10.007

Kuhn, M., 1989. The Response of the Equilibrium Line Altitude to Climate Fluctuations: Theory and Observations, in: Oerlemans, J. (Ed.), . Springer Netherlands, Dordrecht, pp. 407-417. https://doi.org/10.1007/978-94-015-7823-3_26

Kull, C., Grosjean, M., 2000. Late Pleistocene climate conditions in the north Chilean Andes drawn from a climate-glacier model. J. Glaciol. 46, 622-632. https://doi.org/10.3189/172756500781832611

Kull, C., Hänni, F., Grosjean, M., Veit, H., 2003. Evidence of an LGM cooling in NW-Argentina $\left(22^{\circ}\right.$ S) derived from a glacier climate model. Quat. Int. 108, 3-11. https://doi.org/10.1016/S1040-6182(02)00190-8

Kull, C., Imhof, S., Grosjean, M., Zech, R., Veit, H., 2008. Late Pleistocene glaciation in the Central Andes: Temperature versus humidity control - A case study from the eastern Bolivian Andes $\left(17^{\circ} \mathrm{S}\right)$ and regional synthesis. Glob. Planet. Change 60, 148-164. https://doi.org/10.1016/j.gloplacha.2007.03.011

Lal, D., 1991. Cosmic ray labeling of erosion surfaces: in situ nuclide production rates and erosion models. Earth Planet. Sci. Lett. 104, 424-439. https://doi.org/10.1016/0012-821X(91)90220-C

Leclercq, P.W., Oerlemans, J., Basagic, H.J., Bushueva, I., Cook, A.J., Le Bris, R., 2014. A data set of worldwide glacier length fluctuations. Cryosph. 8, 659-672. https://doi.org/10.5194/tc-8-659-2014

Lenters, J.D., Cook, K.H., 1999. Summertime Precipitation Variability over South America: Role of the Large-Scale Circulation. Mon. Weather Rev. 127, 409-431. https://doi.org/10.1175/15200493(1999)127<0409:SPVOSA>2.0.CO;2

Licciardi, J.M., Schaefer, J.M., Taggart, J.R., Lund, D.C., 2009. Holocene glacier fluctuations in the Peruvian Andes indicate northern climate linkages. Science 325, 1677-9. https://doi.org/10.1126/science.1175010

Lifton, N., 2016. Implications of two Holocene time-dependent geomagnetic models for cosmogenic nuclide production rate scaling. Earth Planet. Sci. Lett. 433, 257-268. https://doi.org/10.1016/j.eps1.2015.11.006

Lifton, N., Sato, T., Dunai, T.J., 2014. Scaling in situ cosmogenic nuclide production rates using analytical approximations to atmospheric cosmic-ray fluxes. Earth Planet. Sci. Lett. 386, 149-160. https://doi.org/10.1016/j.epsl.2013.10.052

Loibl, D., Lehmkuhl, F., Grießinger, J., 2014. Reconstructing glacier retreat since the Little Ice Age in SE Tibet by glacier mapping and equilibrium line altitude calculation. Geomorphology 214, 22-39. https://doi.org/10.1016/j.geomorph.2014.03.018

Mabry, J., Burnard, P., Blard, P.-H., Zimmermann, L., 2012. Mapping changes in helium sensitivity and peak shape for varying parameters of a Nier-type noble gas ion source. J. Anal. At. Spectrom. 27, 1012. https://doi.org/10.1039/c2ja10339g

Malone, A.G.O., Pierrehumbert, R.T., Lowell, T. V., Kelly, M.A., Stroup, J.S., 2015. Constraints on southern hemisphere tropical climate change during the Little Ice Age and Younger Dryas based on glacier modeling of the Quelccaya Ice Cap, Peru. Quat. Sci. Rev. 125, 106-116. https://doi.org/10.1016/j.quascirev.2015.08.001

Martin, L.C.P., Blard, P.-H., Balco, G., Lavé, J., Delunel, R., Lifton, N., Laurent, V., 2017. The CREp program and the ICED production rate calibration database: A fully parameterizable and updated online tool to compute cosmic-ray exposure ages. Quat. Geochronol. 38, 25-49. https://doi.org/10.1016/j.quageo.2016.11.006

Martin, L.C.P., Blard, P.-H., Lavé, J., Braucher, R., Lupker, M., Condom, T., Charreau, J., Mariotti, V., ASTER Team, Davy, E., 2015. In situ cosmogenic 10Be production rate in the High Tropical Andes. Quat. Geochronol. 30, 54-68. https://doi.org/10.1016/j.quageo.2015.06.012

Martin, L.C.P., Blard, P.-H., Lavé, J., Condom, T., Prémaillon, M., Jomelli, V., Brunstein, D., Lupker, M., Charreau, J., Mariotti, V., Tibari, B., Davy, E., 2018. Lake Tauca highstand (Heinrich Stadial 1a) driven by a southward shift of the Bolivian High. Sci. Adv. 4, eaar2514. https://doi.org/10.1126/sciadv.aar2514

Matsuda, J., Matsumoto, T., Sumino, H., Nagao, K., Yamamoto, J., Miura, Y., Kaneoka, I., Takahata, N., Sano, Y., 2002. The 3He/4He ratio of the new internal He Standard of Japan (HESJ). Geochem. J. 36, 191-195. https://doi.org/10.2343/geochemj.36.191

McManus, J.F., Francois, R., Gherardi, J.-M., Keigwin, L.D., Brown-Leger, S., 2004. Collapse and rapid resumption of Atlantic meridional circulation linked to deglacial climate changes. Nature 428, 834-837. https://doi.org/10.1038/nature02494

Meierding, T.C., 1982. Late Pleistocene Glacial Equilibrium-Line Front Range: A Comparison Altitudes in the Colorado of Methods. Quat. Res. 18, 289-310. https://doi.org/https://doi.org/10.1016/0033-5894(82)90076-X

Muscheler, R., Beer, J., Kubik, P.W., Synal, H. -a., 2005. Geomagnetic field intensity during the last 60,000 years based on $10 \mathrm{Be}$ and $36 \mathrm{Cl}$ from the Summit ice cores and 14C. Quat. Sci. Rev. 24, 1849-1860. https://doi.org/10.1016/j.quascirev.2005.01.012

New, M., Lister, D., Hulme, M., Makin, I., 2002. A high-resolution data set of surface climate over global land areas. Clim. Res. 21, 1-25. https://doi.org/10.3354/cr021001

Nishiizumi, K., Imamura, M., Caffee, M.W., Southon, J.R., Finkel, R.C., McAninch, J., 2007. Absolute calibration of 10Be AMS standards. Nucl. Instruments Methods Phys. Res. Sect. B Beam Interact. with Mater. Atoms 258, 403-413. https://doi.org/10.1016/j.nimb.2007.01.297

Nunnery, J.A., Fritz, S.C., Baker, P.A., Salenbien, W., 2019. Lake-level variability in Salar de Coipasa, Bolivia during the past $\sim 40,000$ yr. Quat. Res. 91, 881-891. https://doi.org/10.1017/qua.2018.108

Ohmura, A., Kasser, P., Funk, M., 1992. Climate at the Equilibrium Line of Glaciers. J. Glaciol. 38, 397-411. https://doi.org/10.3189/S0022143000002276

Osmaston, H., 2005. Estimates of glacier equilibrium line altitudes by the Area $\times$ Altitude, the Area $\times$ Altitude Balance Ratio and the Area $\times$ Altitude Balance Index methods and their validation. Quat. Int. 138-139, 22-31. https://doi.org/10.1016/j.quaint.2005.02.004 
Palacios, D., Stokes, C.R., Phillips, F.M., Clague, J.J., Alcalá-Reygosa, J., Andres, N., Angel, I., Blard, P.-H., Briner, J.P., Hall, B.L., Dahms, D., Hein, A.S., Jomelli, V., Mark, B.G., Martini, M.A., Moreno, P., Riedel, J., Sagredo, E., Stansell, N.D., Vazquez-Selem, L., Vuille, M., Ward, D.J., 2020. The deglaciation of the Americas during the Last Glacial Termination. Earth-Science Rev. 103113. https://doi.org/10.1016/j.earscirev.2020.103113

Parnell, A.C., Buck, C.E., Doan, T.K., 2011. A review of statistical chronology models for high-resolution, proxy-based Holocene palaeoenvironmental reconstruction. Quat. Sci. Rev. 30, 2948-2960. https://doi.org/10.1016/j.quascirev.2011.07.024

Peterson, L.C., 2000. Rapid Changes in the Hydrologic Cycle of the Tropical Atlantic During the Last Glacial. Science (80-. ). 290, 1947-1951. https://doi.org/10.1126/science.290.5498.1947

Placzek, C., Quade, J., Patchett, P.J., 2006. Geochronology and stratigraphy of late Pleistocene lake cycles on the southern Bolivian Altiplano: Implications for causes of tropical climate change. Geol. Soc. Am. Bull. 118, 515-532. https://doi.org/10.1130/B25770.1

Placzek, C.J., Quade, J., Patchett, P.J., 2013. A 130ka reconstruction of rainfall on the Bolivian Altiplano. Earth Planet. Sci. Lett. 363, 97-108. https://doi.org/10.1016/j.eps1.2012.12.017

Porter, S.C., 2000. Snowline depression in the tropics during the Last Glaciation. Quat. Sci. Rev. 20, 1067-1091. https://doi.org/10.1016/S0277-3791(00)00178-5

Quesada, B., Sylvestre, F., Vimeux, F., Black, J., Paillès, C., Sonzogni, C., Alexandre, A., Blard, P.-H., Tonetto, A., Mazur, J.-C., Bruneton, H., 2015. Impact of Bolivian paleolake evaporation on the $\delta 18 \mathrm{O}$ of the Andean glaciers during the last deglaciation (18.5-11.7 ka): diatom-inferred $\delta 180$ values and hydro-isotopic modeling. Quat. Sci. Rev. 120, 93-106. https://doi.org/10.1016/j.quascirev.2015.04.022

Rabatel, A., Francou, B., Soruco, A., Gomez, J., Cáceres, B., Ceballos, J.L., Basantes, R., Vuille, M., Sicart, J.-E., Huggel, C., Scheel, M., Lejeune, Y., Arnaud, Y., Collet, M., Condom, T., Consoli, G., Favier, V., Jomelli, V., Galarraga, R., Ginot, P., Maisincho, L., Mendoza, J., Ménégoz, M., Ramirez, E., Ribstein, P., Suarez, W., Villacis, M., Wagnon, P., 2013. Current state of glaciers in the tropical Andes: a multi-century perspective on glacier evolution and climate change. Cryosph. 7, 81-102. https://doi.org/10.5194/tc-7-81-2013

Ramirez, E., Hoffmann, G., Taupin, J.., Francou, B., Ribstein, P., Caillon, N., Ferron, F.., Landais, A., Petit, J.., Pouyaud, B., Schotterer, U., Simoes, J.., Stievenard, M., 2003. A new Andean deep ice core from Nevado Illimani (6350 m), Bolivia. Earth Planet. Sci. Lett. 212, 337-350. https://doi.org/10.1016/S0012-821X(03)00240-1

Ramsey, C.B., 2009. BAYESIAN ANALYSIS OF RADIOCARBON DATES Christopher Bronk Ramsey. Radiocarbon 51, 337-360. https://doi.org/10.2458/azu_js_rc.v51i1.3494

Reimer, P., 2013. IntCal13 and Marine13 Radiocarbon Age Calibration Curves 0-50,000 Years cal BP. Radiocarbon 55, 1869-1887. https://doi.org/10.2458/azu js rc.55.16947

Roe, G.H., Lindzen, R.S., 2001. A one-dimensional model for the interaction between continental-scale ice sheets and atmospheric stationary waves. Clim. Dyn. 17, 479-487. https://doi.org/10.1007/s003820000123

Sagredo, E.A., Lowell, T.V., 2012. Climatology of Andean glaciers: A framework to understand glacier response to climate change. Glob. Planet. Change 86-87, 101-109. https://doi.org/10.1016/j.gloplacha.2012.02.010

Satgé, F., Espinoza, R., Zolá, R., Roig, H., Timouk, F., Molina, J., Garnier, J., Calmant, S., Seyler, F., Bonnet, M.-P., 2017. Role of Climate Variability and Human Activity on Poopó Lake Droughts between 1990 and 2015 Assessed Using Remote Sensing Data. Remote Sens. 9, 218. https://doi.org/10.3390/rs9030218

Schimmelpfennig, I., Benedetti, L., Finkel, R., Pik, R., Blard, P.-H., Bourlès, D., Burnard, P., Williams, A., 2009. Sources of in-situ $36 \mathrm{Cl}$ in basaltic rocks. Implications for calibration of production rates. Quat. Geochronol. 4, 441-461. https://doi.org/10.1016/j.quageo.2009.06.003

Schimmelpfennig, I., Williams, A., Pik, R., Burnard, P., Niedermann, S., Finkel, R., Schneider, B., Benedetti, L., 2011. Intercomparison of cosmogenic in-situ $3 \mathrm{He}, 21 \mathrm{Ne}$ and $36 \mathrm{Cl}$ at low latitude along an altitude transect on the SE slope of Kilimanjaro volcano (3??S, Tanzania). Quat. Geochronol. 6, 425-436. https://doi.org/10.1016/j.quageo.2011.05.002

Schneider, C., Glaser, M., Kilian, R., Santana, A., Butorovic, N., Casassa, G., 2003. Weather Observations Across the Southern Andes at $53^{\circ}$ S. Phys. Geogr. 24, 97-119. https://doi.org/10.2747/0272-3646.24.2.97

Segura, H., Junquas, C., Espinoza, J.C., Vuille, M., Jauregui, Y.R., Rabatel, A., Condom, T., Lebel, T., 2019. New insights into the rainfall variability in the tropical Andes on seasonal and interannual time scales. Clim. Dyn. 53, 405-426. https://doi.org/10.1007/s00382-018-4590-8

Seltzer, G.O., 1994. Climatic Interpretation of Alpine Snowline Variations on Millennial Time Scales. Quat. Res. 41, 154159. https://doi.org/10.1006/qres.1994.1017

Shakun, J.D., Clark, P.U., Marcott, S.A., Brook, E.J., Lifton, N.A., Caffee, M., Shakun, W.R., 2015. Cosmogenic dating of Late Pleistocene glaciation, southern tropical Andes, Peru. J. Quat. Sci. 30, 841-847. https://doi.org/10.1002/jqs.2822

Sicart, J.E., Hock, R., Six, D., 2008. Glacier melt, air temperature, and energy balance in different climates: The Bolivian Tropics, the French Alps, and northern Sweden. J. Geophys. Res. 113, D24113. https://doi.org/10.1029/2008JD010406

Sissons, J.B., Sutherland, D.G., 1976. Climatic Inferences from Former Glaciers in the South-East Grampian Highlands, Scotland. J. Glaciol. 17, 325-346. https://doi.org/10.1017/S0022143000013617

Smith, C.A., Lowell, T. V., Caffee, M.W., 2009. Lateglacial and Holocene cosmogenic surface exposure age glacial chronology and geomorphological evidence for the presence of cold-based glaciers at Nevado Sajama, Bolivia. J. Quat. Sci. 24, 360-372. https://doi.org/10.1002/jqs.1239

Smith, J.A., Seltzer, G.O., Farber, D.L., Rodbell, D.T., Finkel, R.C., 2005. Early Local Last Glacial Maximum in the Tropical Andes. Science (80-. ). 308, 678-681. https://doi.org/10.1126/science.1107075

Soruco, A., Vincent, C., Francou, B., Ribstein, P., Berger, T., Sicart, J.E., Wagnon, P., Arnaud, Y., Favier, V., Lejeune, Y., 2009. Mass balance of Glaciar Zongo, Bolivia, between 1956 and 2006, using glaciological, hydrological and geodetic methods. Ann. Glaciol. 50, 1-8. https://doi.org/10.3189/172756409787769799

Stauch, G., Lehmkuhl, F., 2010. Quaternary glaciations in the Verkhoyansk Mountains, Northeast Siberia. Quat. Res. 74, 

https://doi.org/10.1029/2000JB900181

Stríkis, N.M., Chiessi, C.M., Cruz, F.W., Vuille, M., Cheng, H., de Souza Barreto, E.A., Mollenhauer, G., Kasten, S., Karmann, I., Edwards, R.L., Bernal, J.P., Sales, H. dos R., 2015. Timing and structure of Mega-SACZ events during Heinrich Stadial 1. Geophys. Res. Lett. 42, 5477-5484A. https://doi.org/10.1002/2015GL064048

Sylvestre, F., Servant, M., Servant-Vildary, S., Causse, C., Fournier, M., Ybert, J.-P., 1999. Lake-Level Chronology on the Southern Bolivian Altiplano (18 $\left.-23^{\circ} \mathrm{S}\right)$ During Late-Glacial Time and the Early Holocene. Quat. Res. 51, 54-66. https://doi.org/10.1006/qres.1998.2017

Thompson, L.G., Davis, M.E., Mosley-Thompson, E., Sowers, T.A., Henderson, K.A., Zagorodnov, V.S., Lin, P., Mikhalenko, V.N., Campen, R.K., Bolzan, J.F., Cole-Dai, J., Francou, B., 1998. A 25,000-Year Tropical Climate History from Bolivian Ice Cores. Science (80-. ). 282, 1858-1864. https://doi.org/10.1126/science.282.5395.1858

Thompson, L.G., Mosley-Thompson, E., Davis, M.E., Lin, P.N., Henderson, K.A., Cole-Dai, J., Bolzan, J.F., Liu, K.B., 1995. Late Glacial Stage and Holocene Tropical Ice Core Records from Huascaran, Peru. Science (80-. ). 269, 46-50. https://doi.org/10.1126/science.269.5220.46

Toggweiler, J.R., 2009. Climate change: Shifting Westerlies. Science (80-. ). 323, 1434-1435. https://doi.org/10.1126/science.1169823

Toggweiler, J.R., Russell, J.L., Carson, S.R., 2006. Midlatitude westerlies, atmospheric CO 2 , and climate change during the ice ages. Paleoceanography 21, n/a-n/a. https://doi.org/10.1029/2005PA001154

Uppala, S.M., KÅllberg, P.W., Simmons, a. J., Andrae, U., Bechtold, V.D.C., Fiorino, M., Gibson, J.K., Haseler, J., Hernandez, A., Kelly, G. a., Li, X., Onogi, K., Saarinen, S., Sokka, N., Allan, R.P., Andersson, E., Arpe, K., Balmaseda, M. a., Beljaars, a. C.M., Berg, L. Van De, Bidlot, J., Bormann, N., Caires, S., Chevallier, F., Dethof, A., Dragosavac, M., Fisher, M., Fuentes, M., Hagemann, S., Hólm, E., Hoskins, B.J., Isaksen, L., Janssen, P. a. E.M., Jenne, R., Mcnally, a. P., Mahfouf, J.-F., Morcrette, J.-J., Rayner, N. a., Saunders, R.W., Simon, P., Sterl, A., Trenberth, K.E., Untch, A., Vasiljevic, D., Viterbo, P., Woollen, J., 2005. The ERA-40 re-analysis. Q. J. R. Meteorol. Soc. 131, 2961-3012. https://doi.org/10.1256/qj.04.176

Vera, C., Higgins, W., Amador, J., Ambrizzi, T., Garreaud, R., Gochis, D., Gutzler, D., Lettenmaier, D., Marengo, J., Mechoso, C.R., Nogues-Paegle, J., Dias, P.L.S., Zhang, C., 2006. Toward a Unified View of the American Monsoon Systems. J. Clim. 19, 4977-5000. https://doi.org/10.1175/JCLI3896.1

Vuille, M., 1999. Atmospheric circulation over the Bolivian Altiplano during dry and wet periods and extreme phases of the Southern Oscillation. Int. J. Climatol. 19, 1579-1600. https://doi.org/10.1002/(SICI)10970088(19991130)19:14<1579::AID-JOC441>3.0.CO;2-N

Vuille, M., Francou, B., Wagnon, P., Juen, I., Kaser, G., Mark, B.G., Bradley, R.S., 2008. Climate change and tropical Andean glaciers: Past, present and future. Earth-Science Rev. 89, 79-96. https://doi.org/10.1016/j.earscirev.2008.04.002

Vuille, M., Keimig, F., 2004. Interannual Variability of Summertime Convective Cloudiness and Precipitation in the Central Andes Derived from ISCCP-B3 Data. J. Clim. 17, 3334-3348. https://doi.org/10.1175/15200442(2004)017<3334:IVOSCC $>2.0 . \mathrm{CO} ; 2$

Wang, X., Auler, A.S., Edwards, R.L., Cheng, H., Ito, E., Wang, Y., Kong, X., Solheid, M., 2007. Millennial-scale precipitation changes in southern Brazil over the past 90,000 years. Geophys. Res. Lett. 34, 1-5. https://doi.org/10.1029/2007GL031149

Ward, D.J., Cesta, J.M., Galewsky, J., Sagredo, E., 2015. Late Pleistocene glaciations of the arid subtropical Andes and new results from the Chajnantor Plateau, northern Chile. Quat. Sci. Rev. 128, 98-116. https://doi.org/10.1016/j.quascirev.2015.09.022

Xu, C.-Y., Singh, V.P., 2000. Evaluation and generalization of radiation-based methods for calculating evaporation. Hydrol. Process. 14, 339-349. https://doi.org/10.1002/(SICI)1099-1085(20000215)14:2<339::AID-HYP928>3.0.CO;2-O

Zech, J., Zech, R., Kubik, P.W., Veit, H., 2009. Glacier and climate reconstruction at Tres Lagunas, NW Argentina, based on 10Be surface exposure dating and lake sediment analyses. Palaeogeogr. Palaeoclimatol. Palaeoecol. 284, 180-190. https://doi.org/10.1016/j.palaeo.2009.09.023

Zhang, X., Lohmann, G., Knorr, G., Purcell, C., 2014. Abrupt glacial climate shifts controlled by ice sheet changes. Nature 512, 290-294. https://doi.org/10.1038/nature13592

Zhou, J., Lau, K.-M., 1998. Does a Monsoon Climate Exist over South America? J. Clim. 11, 1020-1040. https://doi.org/10.1175/1520-0442(1998)011<1020:DAMCEO >2.0.CO;2

Zimmermann, L., Blard, P.H., Burnard, P., Medynski, S., Pik, R., Puchol, N., 2012. A New Single Vacuum Furnace Design for Cosmogenic 3He Dating. Geostand. Geoanalytical Res. 36, 121-129. https://doi.org/10.1111/j.1751908X.2011.00145.X 


\section{Supplementary Information}

\section{S.1. Additional ${ }^{\mathbf{1 0}}$ Be data for Zongo Valley}

\begin{tabular}{|c|c|c|c|c|c|c|c|c|c|c|}
\hline Moraine & Sample & $\begin{array}{c}\text { Latitude } \\
\text { Dec }^{\circ}\end{array}$ & $\begin{array}{c}\text { Longitude } \\
\text { Dec }^{\circ}\end{array}$ & $\begin{array}{c}\text { Altitude } \\
\text { masl }\end{array}$ & $\begin{array}{c}{ }^{10} \mathrm{Be}(\mathbf{1 \sigma}) \\
10^{5} \text { at. } \mathrm{g}^{-1} \\
\end{array}$ & $\begin{array}{c}\text { Thickness } \\
\mathrm{cm} \\
\end{array}$ & $\begin{array}{c}\text { Thick. Corr. }^{\mathrm{a}} \\
- \\
\end{array}$ & $\begin{array}{c}\text { Shielding }^{\mathrm{b}} \\
- \\
\end{array}$ & $\begin{array}{c}\text { Scaling Factor }^{c} \\
- \\
\end{array}$ & $\begin{array}{c}\text { Age }(\mathbf{1 \sigma})^{\mathrm{d}} \\
k a \\
\end{array}$ \\
\hline \multirow{4}{*}{ T1 } & B1 & -16.2601 & -68.1132 & 4529 & $4.87 \pm 0.42$ & 4 & 0.97 & 0.99 & 10.0 & $12.5 \pm 1.1$ \\
\hline & B2 & -16.2610 & -68.1123 & 4609 & $5.02 \pm 0.43$ & 4 & 0.97 & 0.98 & 10.4 & $12.5 \pm 1.1$ \\
\hline & B3 & -16.2580 & -68.1136 & 4434 & $3.49 \pm 0.20$ & 3 & 0.98 & 0.96 & 9.4 & $9.7 \pm 0.6$ \\
\hline & B4 & -16.2611 & -68.1123 & 4698 & $3.36 \pm 0.34$ & 3 & 0.98 & 0.99 & 10.5 & $8.2 \pm 0.8$ \\
\hline \multirow{29}{*}{$\mathrm{T} 2$} & B5 & -16.2606 & -68.1121 & 4581 & $3.32 \pm 0.18$ & 4 & 0.97 & 0.97 & 10.0 & $8.7 \pm 0.5$ \\
\hline & B6 & -16.2586 & -68.1136 & 4475 & $4.74 \pm 0.19$ & 4 & 0.97 & 0.98 & 9.8 & $12.6 \pm 0.6$ \\
\hline & B7 & -16.2597 & -68.1118 & 4536 & $4.46 \pm 0.27$ & 3 & 0.97 & 0.98 & 10.0 & $11.5 \pm 0.7$ \\
\hline & B8 & -16.2605 & -68.1119 & 4580 & $4.23 \pm 0.14$ & 4 & 0.97 & 0.98 & 10.1 & $10.9 \pm 0.4$ \\
\hline & B9 & -16.2574 & -68.1098 & 4605 & $3.94 \pm 0.43$ & 4 & 0.97 & 0.98 & 10.2 & $10.1 \pm 1.0$ \\
\hline & B10 & -16.2605 & -68.1118 & 4575 & $3.85 \pm 0.48$ & 4 & 0.97 & 0.99 & 10.0 & $9.9 \pm 1.2$ \\
\hline & B11 & -16.2578 & -68.1122 & 4503 & $3.29 \pm 0.45$ & 4 & 0.97 & 0.94 & 9.7 & $9.2 \pm 1.2$ \\
\hline & B12 & -16.2599 & -68.1121 & 4534 & $4.25 \pm 0.12$ & 4 & 0.97 & 1.00 & 9.9 & $10.9 \pm 0.4$ \\
\hline & B13 & -16.2576 & -68.1110 & 4559 & $0.60 \pm 0.35$ & 4 & 0.96 & 0.97 & 9.1 & $1.7 \pm 1.0$ \\
\hline & B14 & -16.2573 & -68.1093 & 4624 & $2.92 \pm 0.79$ & 4 & 0.96 & 0.97 & 10.1 & $7.7 \pm 1.8$ \\
\hline & B15 & -16.2597 & -68.1119 & 4479 & $4.41 \pm 0.13$ & 3 & 0.97 & 0.98 & 9.8 & $11.6 \pm 0.4$ \\
\hline & B16 & -16.2575 & -68.1093 & 4619 & $4.52 \pm 0.21$ & 4 & 0.97 & 0.99 & 10.4 & $11.2 \pm 0.5$ \\
\hline & B17 & -16.2601 & -68.1109 & 4601 & $4.38 \pm 0.12$ & 4 & 0.97 & 0.98 & 10.3 & $11.1 \pm 0.4$ \\
\hline & B18 & -16.2601 & -68.1109 & 4553 & $4.27 \pm 0.64$ & 4 & 0.97 & 0.98 & 10.0 & $11.1 \pm 1.5$ \\
\hline & B19 & -16.2601 & -68.1115 & 4553 & $4.37 \pm 0.24$ & 4 & 0.97 & 0.98 & 10.1 & $11.3 \pm 0.6$ \\
\hline & B20 & -16.2601 & -68.1109 & 4584 & $4.44 \pm 0.14$ & 3 & 0.97 & 0.98 & 10.2 & $11.3 \pm 0.4$ \\
\hline & B21 & -16.2580 & -68.1097 & 4579 & $4.05 \pm 0.15$ & 4 & 0.96 & 0.98 & 10.1 & $10.4 \pm 0.4$ \\
\hline & B22 & -16.2602 & -68.1105 & 4540 & $4.59 \pm 0.13$ & 3 & 0.97 & 0.98 & 10.1 & $11.8 \pm 0.4$ \\
\hline & B23 & -16.2600 & -68.1102 & 4561 & $3.89 \pm 0.19$ & 4 & 0.97 & 0.97 & 10.0 & $10.2 \pm 0.5$ \\
\hline & B24 & -16.2602 & -68.1101 & 4562 & $3.84 \pm 0.34$ & 4 & 0.96 & 0.98 & 10.0 & $10.1 \pm 0.9$ \\
\hline & B25 & -16.2578 & -68.1090 & 4608 & $4.02 \pm 0.29$ & 4 & 0.96 & 0.99 & 10.2 & $10.2 \pm 0.7$ \\
\hline & B26 & -16.2601 & -68.1099 & 4547 & $4.45 \pm 0.10$ & 4 & 0.97 & 0.98 & 10.1 & $11.5 \pm 0.3$ \\
\hline & B27 & -16.2578 & -68.1086 & 4619 & $4.03 \pm 0.51$ & 4 & 0.97 & 0.98 & 10.2 & $10.2 \pm 1.2$ \\
\hline & B28 & -16.2594 & -68.1097 & 4562 & $3.52 \pm 0.40$ & 4 & 0.97 & 0.97 & 9.9 & $9.2 \pm 1.0$ \\
\hline & B29 & -16.2594 & -68.1097 & 4562 & $3.48 \pm 0.25$ & 3 & 0.97 & 0.97 & 9.9 & $9.1 \pm 0.7$ \\
\hline & B30 & -16.2576 & -68.1084 & 4630 & $4.53 \pm 0.21$ & 4 & 0.96 & 0.98 & 10.4 & $11.3 \pm 0.5$ \\
\hline & B31 & -16.2606 & -68.1081 & 4605 & $3.53 \pm 0.45$ & 4 & 0.97 & 0.98 & 10.1 & $9.1 \pm 1.1$ \\
\hline & B32 & -16.2593 & -68.1092 & 4551 & $4.31 \pm 0.16$ & 4 & 0.97 & 0.98 & 10.0 & $11.1 \pm 0.4$ \\
\hline & B33 & -16.2599 & -68.1090 & 4548 & $4.14 \pm 0.49$ & 4 & 0.97 & 0.98 & 10.0 & $10.7 \pm 1.2$ \\
\hline \multirow{26}{*}{ T3 } & B34 & -16.2599 & -68.1090 & 4548 & $4.58 \pm 0.34$ & 4 & 0.97 & 0.98 & 10.1 & $11.7 \pm 0.8$ \\
\hline & B35 & -16.2575 & -68.1076 & 4632 & $3.86 \pm 0.40$ & 4 & 0.97 & 0.98 & 10.3 & $9.8 \pm 1.0$ \\
\hline & B36 & -16.2594 & -68.1124 & 4706 & $4.16 \pm 0.16$ & 4 & 0.97 & 0.97 & 10.6 & $10.3 \pm 0.4$ \\
\hline & B37 & -16.2598 & -68.1071 & 4612 & $3.23 \pm 0.24$ & 4 & 0.97 & 0.98 & 10.1 & $8.3 \pm 0.6$ \\
\hline & B38 & -16.2597 & -68.1069 & 4640 & $3.65 \pm 0.20$ & 3 & 0.98 & 0.98 & 10.3 & $9.2 \pm 0.5$ \\
\hline & в39 & -16.2596 & -68.1070 & 4734 & $4.16 \pm 0.15$ & 3 & 0.98 & 0.98 & 10.7 & $10.0 \pm 0.4$ \\
\hline & B40 & -16.2594 & -68.1070 & 4642 & $3.92 \pm 0.15$ & 3 & 0.98 & 0.98 & 10.3 & $9.8 \pm 0.4$ \\
\hline & B41 & -16.2598 & -68.1068 & 4639 & $3.59 \pm 0.35$ & 3 & 0.98 & 0.99 & 10.2 & $9.0 \pm 0.8$ \\
\hline & B42 & -16.2579 & -68.1064 & 4630 & $3.97 \pm 0.15$ & 3 & 0.97 & 0.97 & 10.3 & $10.1 \pm 0.4$ \\
\hline & B43 & -16.2592 & -68.1069 & 4642 & $4.08 \pm 0.15$ & 3 & 0.98 & 0.98 & 10.3 & $10.2 \pm 0.4$ \\
\hline & B44 & -16.2600 & -68.1061 & 4647 & $4.02 \pm 0.17$ & 3 & 0.98 & 0.99 & 10.3 & $10.0 \pm 0.5$ \\
\hline & B45 & -16.2592 & -68.1069 & 4641 & $4.42 \pm 0.15$ & 3 & 0.98 & 0.98 & 10.4 & $10.9 \pm 0.4$ \\
\hline & B46 & -16.2591 & -68.1066 & 4607 & $2.75 \pm 0.20$ & 4 & 0.97 & 0.98 & 9.9 & $7.2 \pm 0.5$ \\
\hline & B47 & -16.2574 & -68.1061 & 4646 & $3.95 \pm 0.39$ & 4 & 0.97 & 0.98 & 10.3 & $9.9 \pm 0.9$ \\
\hline & B48 & -16.2577 & -68.1060 & 4640 & $4.08 \pm 0.42$ & 3 & 0.97 & 0.98 & 10.3 & $10.2 \pm 1.0$ \\
\hline & B49 & -16.2577 & -68.1060 & 4641 & $4.17 \pm 0.27$ & 4 & 0.97 & 0.97 & 10.4 & $10.6 \pm 0.7$ \\
\hline & B50 & -16.2595 & -68.1054 & 4648 & $3.65 \pm 0.20$ & 3 & 0.98 & 0.97 & 10.3 & $9.2 \pm 0.5$ \\
\hline & B51 & -16.2599 & -68.1050 & 4655 & $3.78 \pm 0.13$ & 3 & 0.98 & 0.98 & 10.3 & $9.4 \pm 0.4$ \\
\hline & B52 & -16.2592 & -68.1054 & 4652 & $4.04 \pm 0.14$ & 3 & 0.98 & 0.97 & 10.4 & $10.1 \pm 0.4$ \\
\hline & B53 & -16.2594 & -68.1044 & 4668 & $3.63 \pm 0.13$ & 3 & 0.98 & 0.98 & 10.4 & $9.0 \pm 0.4$ \\
\hline & B54 & -16.2586 & -68.1047 & 4671 & $4.24 \pm 0.15$ & 3 & 0.98 & 0.99 & 10.5 & $10.3 \pm 0.4$ \\
\hline & B55 & -16.2592 & -68.1045 & 4667 & $4.24 \pm 0.15$ & 3 & 0.98 & 0.98 & 10.5 & $10.4 \pm 0.4$ \\
\hline & B56 & -16.2586 & -68.1048 & 4669 & $4.34 \pm 0.15$ & 3 & 0.98 & 0.99 & 10.5 & $10.6 \pm 0.4$ \\
\hline & B57 & -16.2594 & -68.1041 & 4666 & $4.33 \pm 0.15$ & 3 & 0.98 & 0.97 & 10.5 & $10.7 \pm 0.4$ \\
\hline & B58 & -16.2571 & -68.1016 & 4703 & $0.31 \pm 0.04$ & 3 & 0.98 & 0.99 & 10.0 & $0.8 \pm 0.1$ \\
\hline & B59 & -16.2572 & -68.1016 & 4734 & $0.09 \pm 0.01$ & 3 & 0.98 & 0.98 & 10.8 & $0.20 \pm 0.03$ \\
\hline \multicolumn{11}{|c|}{ 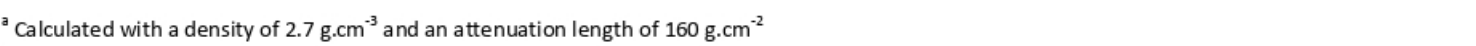 } \\
\hline \multicolumn{11}{|c|}{${ }^{b}$ Calculated using the CRONUS shielding application } \\
\hline \multicolumn{11}{|c|}{ 'Global scaling factor that accounts for the geomagnetic correction } \\
\hline \multicolumn{11}{|c|}{ ¿PR: weighted mean of Kelly et al. (2013), Blard et al. (2013b) and Martin et al. (2015) - Scaling: Lal modified - Atmosphere: ERA40 - VDM: Muscheler et al. (2005) } \\
\hline
\end{tabular}




\begin{tabular}{|c|c|c|c|c|c|c|c|}
\hline Moraine & Sample & $\begin{array}{c}\text { Mass of quartz } \\
g\end{array}$ & Measured ${ }^{10} \mathrm{Be} /{ }^{9} \mathrm{Be}^{\mathrm{a}}$ & ${ }^{10}$ Be counts & Blank ${ }^{10} \mathrm{Be} /{ }^{9} \mathrm{Be}^{\mathrm{b}}$ & $\begin{array}{c}{ }^{9} \mathrm{Be} \text { carrier } \\
\text { at }\end{array}$ & $\begin{array}{l}{ }_{\mathrm{B}}^{10} \mathrm{Be} \pm 1 \sigma^{\mathrm{c}} \\
10^{5} \text { at. }^{-1}\end{array}$ \\
\hline \multirow{10}{*}{ MV } & MB9 & 3.74 & $1.00 \mathrm{E}-13$ & 187 & $2.68 \mathrm{E}-15$ & $2.06 \mathrm{E}+19$ & $5.38 \pm 0.29$ \\
\hline & MB10 & 12.36 & $3.11 \mathrm{E}-13$ & 1224 & $2.68 \mathrm{E}-15$ & $2.07 E+19$ & $5.16 \pm 0.16$ \\
\hline & MB11 & 6.44 & $1.39 \mathrm{E}-13$ & 1012 & $2.68 \mathrm{E}-15$ & $2.07 E+19$ & $4.38 \pm 0.16$ \\
\hline & MB12 & 1.99 & $7.79 \mathrm{E}-14$ & 618 & $2.68 \mathrm{E}-15$ & $2.07 E+19$ & $7.82 \pm 0.38$ \\
\hline & MB13 & 2.14 & $4.23 \mathrm{E}-14$ & 344 & $2.68 \mathrm{E}-15$ & $2.04 \mathrm{E}+19$ & $3.79 \pm 0.24$ \\
\hline & MB14 & 6.28 & $1.60 \mathrm{E}-13$ & 170 & $2.68 \mathrm{E}-15$ & $2.06 \mathrm{E}+19$ & $5.16 \pm 0.26$ \\
\hline & Zong-13-01 & 12.13 & $8.78 \mathrm{E}-14$ & 965 & $1.46 \mathrm{E}-15$ & $4.18 \mathrm{E}+19$ & $2.97 \pm 0.11$ \\
\hline & Zong-13-02 & 11.03 & $7.79 \mathrm{E}-14$ & 887 & $1.46 \mathrm{E}-15$ & 4.19E+19 & $2.90 \pm 0.11$ \\
\hline & Zong-13-03 & 10.93 & $5.58 \mathrm{E}-14$ & 564 & $1.46 \mathrm{E}-15$ & $4.18 \mathrm{E}+19$ & $2.08 \pm 0.10$ \\
\hline & Zong-13-04 & 7.92 & $6.64 \mathrm{E}-14$ & 799 & $1.46 \mathrm{E}-15$ & $4.18 \mathrm{E}+19$ & $3.43 \pm 0.15$ \\
\hline \multirow{5}{*}{ CQ1 } & CNB1 & 3.96 & $9.89 \mathrm{E}-14$ & 308 & $2.68 \mathrm{E}-15$ & $2.05 E+19$ & $4.99 \pm 0.31$ \\
\hline & CNB2 & 7.84 & $1.82 \mathrm{E}-13$ & 1215 & $2.68 \mathrm{E}-15$ & $2.07 E+19$ & $4.74 \pm 0.16$ \\
\hline & CNB3 & 7.49 & $1.79 \mathrm{E}-13$ & 1230 & $2.68 \mathrm{E}-15$ & $2.06 \mathrm{E}+19$ & $4.85 \pm 0.16$ \\
\hline & CNB4 & 14.08 & $3.15 \mathrm{E}-13$ & 696 & $2.68 \mathrm{E}-15$ & $2.05 \mathrm{E}+19$ & $4.56 \pm 0.19$ \\
\hline & CNB5 & 6.80 & $1.61 \mathrm{E}-13$ & 804 & $2.68 \mathrm{E}-15$ & $2.04 \mathrm{E}+19$ & $4.76 \pm 0.19$ \\
\hline \multirow{5}{*}{ CQ3 } & CNB16 & 13.10 & $2.38 \mathrm{E}-13$ & 1110 & $3.89 \mathrm{E}-15$ & $2.11 \mathrm{E}+19$ & $3.77 \pm 0.13$ \\
\hline & CNB17 & 22.38 & $4.49 \mathrm{E}-13$ & 1155 & $3.89 \mathrm{E}-15$ & $2.08 \mathrm{E}+19$ & $4.15 \pm 0.15$ \\
\hline & CNB18 & 8.60 & $1.68 \mathrm{E}-13$ & 1218 & $3.89 \mathrm{E}-15$ & $2.11 \mathrm{E}+19$ & $4.03 \pm 0.13$ \\
\hline & CNB19 & 7.37 & $1.48 \mathrm{E}-13$ & 364 & $3.89 \mathrm{E}-15$ & $2.10 \mathrm{E}+19$ & $4.11 \pm 0.25$ \\
\hline & CNB20 & 15.86 & $2.84 \mathrm{E}-13$ & 779 & $3.89 \mathrm{E}-15$ & $2.10 \mathrm{E}+19$ & $3.71 \pm 0.14$ \\
\hline \multirow{3}{*}{ CQ4 } & CNB11 & 19.32 & $3.64 \mathrm{E}-13$ & 1240 & $3.89 \mathrm{E}-15$ & $2.11 \mathrm{E}+19$ & $3.94 \pm 0.13$ \\
\hline & CNB13 & 9.43 & $1.80 \mathrm{E}-13$ & 797 & $3.89 \mathrm{E}-15$ & $2.12 \mathrm{E}+19$ & $3.96 \pm 0.17$ \\
\hline & CNB15 & 11.05 & $2.06 \mathrm{E}-13$ & 1212 & $3.89 \mathrm{E}-15$ & $2.11 \mathrm{E}+19$ & $3.88 \pm 0.13$ \\
\hline
\end{tabular}

\section{S.2. Hydrologic connection between the Altiplano sub-basins}

We used the shoreline archive to provide hydrological constraints on our climatic inversions

1444 based the on hydrologic budget of the southern basin lake at a given level. Because the hydrologic

1445 connection between the four basins of the Altiplano during the late-glacial period has not been proven,

1446 computing the relevant hydrologic budget required that we determine which basins were connected to

1447 the southern basin for a given set of $\Delta T$ and $\Delta P$ values (relative to present-day values).

1448 We computed the hydrological balance of each sub-basin watershed balance sequentially to

1449 evaluate the connection between each basin and its downstream counterpart(s). First, we computed the

1450 Titicaca overflow toward the Poopo basin, then the annual hydrologic budgets for the Poopo basin,

1451 allowing lake-level adjustments from one year to another until reaching a steady state. If this steady

1452 state corresponds to an overflow towards the Coipasa basin, we determine the corresponding input for

1453 the Coipasa. We applied the same approach to the Coipasa basin to see if it overflows into the Uyuni

1454 basin. We thusly identified the basins hydrologically connected with the southern basin, for which we

1455 know the lake level from shoreline ages. We finally computed the hydrological budget for the identified basins and solved for $\Delta T$ and $\Delta P$. 
The initial steps of this calculation are presented in Section 3.3.5. Within each sector, the

1459 punctual $A_{\text {Tauca }}(x, y)$ value was associated to its normalized distance $r^{*}$ s to the barycenter, taken as the 1460 actual distance divided by the sector's lake radius. From these values, a scatter plot of $A_{\text {Tauca }}=f\left(r^{*} \mathrm{~s}\right)$ was 1461 constructed for each sector, and a curve averaging the point cloud was constructed. Thus, for the Tauca 1462 highstand, we produced a set of 20 curves describing the radial evolution of the anomaly from the 1463 barycenter of Lake Tauca along the normalized distance $r^{*}$ s. Because each of these curves averages this 1464 behavior over a given angular sector, we associated each $A\left(r^{*} \mathrm{~s}\right)$ curve with $\theta_{\mathrm{S}}$, the angle (in radians) 1465 between the bisector of sector S and a reference vector (due south).

1466 Then, for any time $t$ of the last deglaciation, we proceeded as follows. We first derived the lake 1467 level from the shoreline dataset. We then derived the lake extent from this elevation and the DEM of 1468 the basin, and calculated its barycenter. From the barycenter, we divided the basin into 20 angular sectors 1469 and calculated the mean lake radius per sector (see Section 3.3.5). We then calculated $r_{i}{ }_{i}$ and $\theta_{i}$ for each 1470 point $i$ in the sector. We then used the set of $20 A\left(r^{*} \mathrm{~s}\right)$ curves in $\theta_{\mathrm{S}}-r^{*} \mathrm{~s}$ space to perform a $2 \mathrm{D}$ polar 1471 interpolation of the values of $A$ in $\theta_{i}-r^{*}{ }_{i}$ space. We were thus able to calculate the grid $A$ for any lake 1472 configuration of the study period. This algorithm was implemented such that during the Tauca 1473 highstand, the anomaly algorithm was bypassed and the grid $A$ input into the lake model was the original 1474 grid directly derived from the results of Martin et al. (2018). The reconstructed anomaly fields (given 1475 as $\beta \times A$ ) for the Coipasa and Tauca highstands are shown in Figure 10, and a graphical illustration of 1476 the anomaly algorithm is provided in Figure S3. 


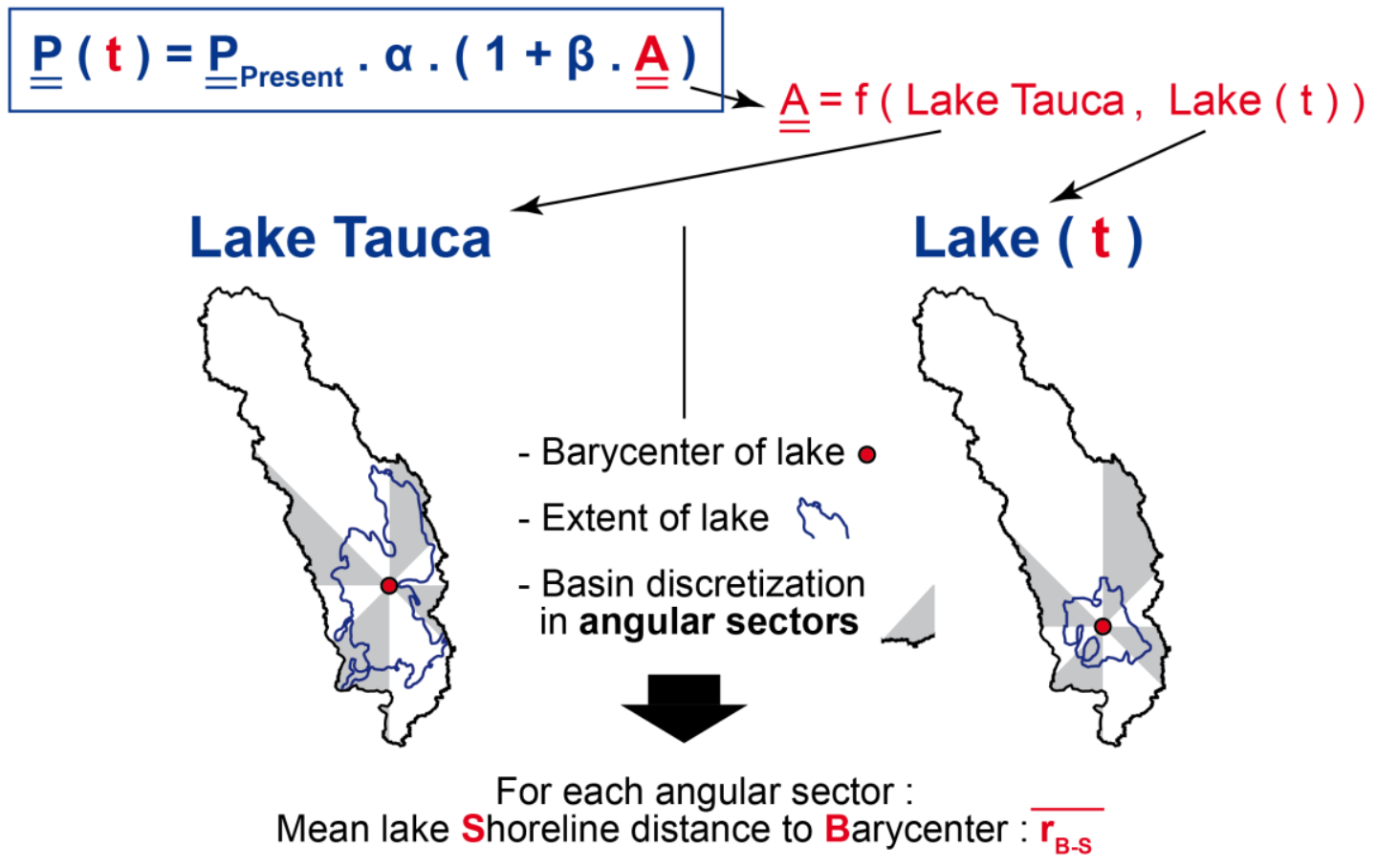

KNOWN : (Martin et al., 2018)

$\left.\begin{array}{l}-P_{\text {Tauca }} / P_{\text {Present }} \\ -\alpha_{\text {Tauca }} \\ -\beta_{\text {Tauca }}\end{array}\right\} \Rightarrow \boldsymbol{A}_{\text {Tauca }}$

For each angular sector, considering the angle $\theta_{s}$, to the bissector of each sector, we consider the $\mathcal{A}_{\theta_{s}}\left(r^{*}{ }_{s}\right)$ mean curve as follow :

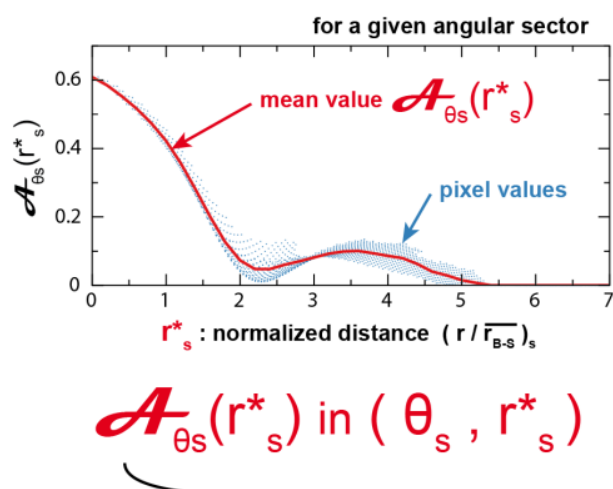

WANTED :

\section{$\stackrel{A}{=}(\mathrm{t})$}

For each pixel $i$ in the basin, we consider its radial coordinate relative to the barycenter : $\theta_{i}$ and $r_{i}$

And then normalize $r_{i}$ considering its angular sector :

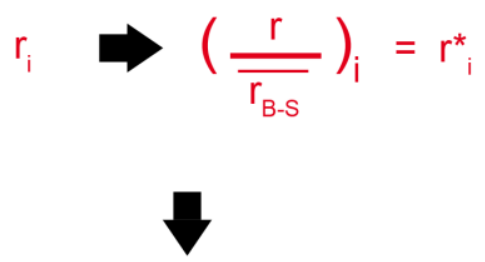

$\left(\theta_{i}, r_{i}^{*}\right)$
Figure S3. Workflow to compute the precipitation anomaly grid. The workflow describes the computation of matrix A as described in Section 3.3.5 and Equation (3). Matrix A was computed based on the Tauca highstand case study of Martin et al. (2018). The matrix A for the Tauca highstand was discretized from the barycenter of Lake Tauca into different angular sectors ("pie slices") such that it can be summed as a set of curves describing the decrease of A with distance from the barycenter. These curves were then used for any lake configuration during the last deglaciation by employing a scaling procedure that accounts for the location of the lake and its spatial extent. We note that for legibility, the schematic diagram s divided into eight angular sectors instead of the twenty used in the computation. 
1488 be linked to lake size (Table S4, Fig. S4). Because the sizes of Lake Coipasa $\left(32,300 \mathrm{~km}^{2}\right)$ and Lake 1489 Tauca $\left(52,000 \mathrm{~km}^{2}\right)$ differ, and because we also dealt with their transgressive and regressive states 1490 synchronous with the reported ice extents, we calibrated $\beta$ to account for this size-dependence (see 1491 Section 3.3.5 and Equation 4) using the data presented in Table S4 and Figure S4.

\begin{tabular}{|c|c|c|c|}
\hline Lake & Surface $\left.\mathbf{( k m}^{\mathbf{2}}\right)$ & Observed $\boldsymbol{\beta}$ & Uncertainty \\
\hline Lake Mweru & 5022 & 0.2 & 0.1 \\
\hline Lake Titicaca & 8562 & 0.4 & 0.1 \\
\hline Lake Malawi & 29429 & 0.8 & 0.1 \\
\hline Lake Victoria & 68800 & 0.9 & 0.1 \\
\hline
\end{tabular}

Table S4. Dataset used to empirically calibrate $\beta$. Source: www. lakebasin.org.

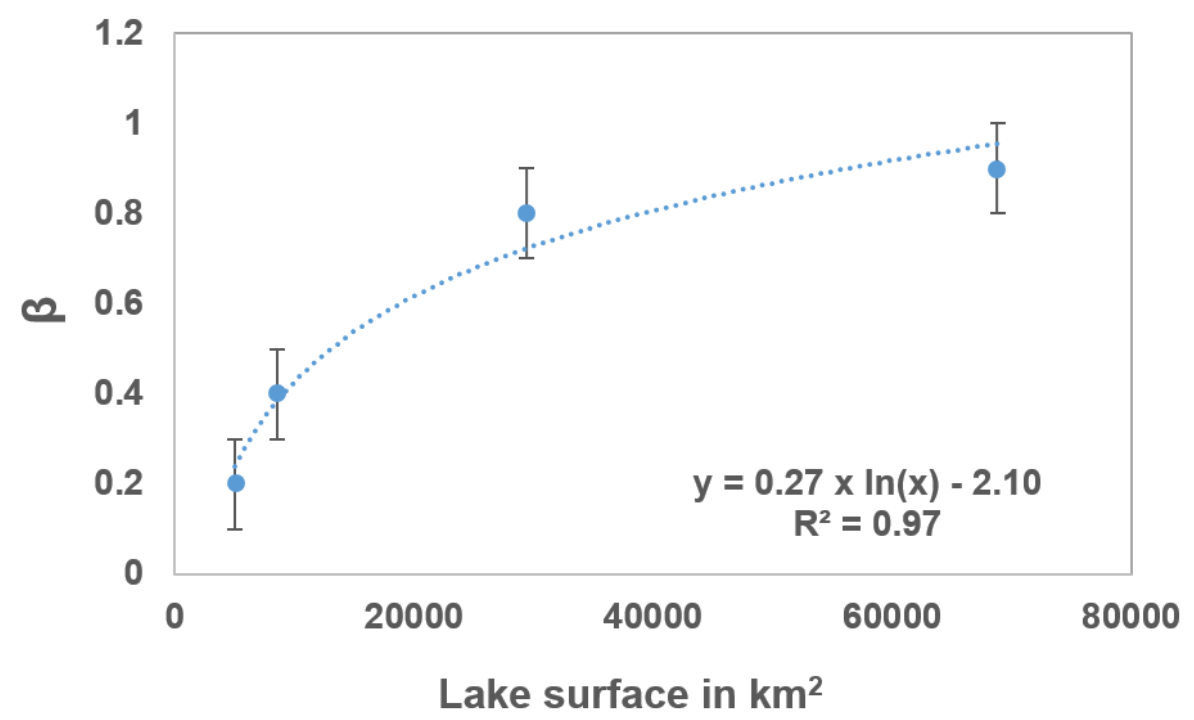




\section{S.5. Impact of the scaling scheme model on the CRE age computations}

To assess the dependence of the computed ages to the scaling procedure, we used CREp

1498 (https://crep.otelo.univ-lorraine.fr) to re-compute all the ages of this study using a different scaling

1499 framework. In Fig. S5, we compare the ages obtained with the Lal/Stone ('Lm') time-dependent scaling

1500 model (Balco et al., 2008) and the geomagnetic database of Muscheler et al. (2005) to those obtained

1501 with the LSD scaling model (Lifton et al., 2014) and the Lifton (2016) geomagnetic database. Both

1502 calculations rely on the ERA40 atmospheric database (Uppala et al., 2005). This comparison

1503 demonstrates that our results show little dependence on the scaling procedure. The Lm scaling tends to

1504 produce ages 400 years older than the LSD scaling. Given the uncertainties on the measurements, this

1505 difference indicates that $90 \%$ of the computed ages are compatible within $1 \sigma$. For the other $10 \%$, the

1506 average $1 \sigma$ incompatibility is 100 years. Hence, the CRE ages have very limited model dependence,

1507 underlying the robustness of the reported glacial chronologies.

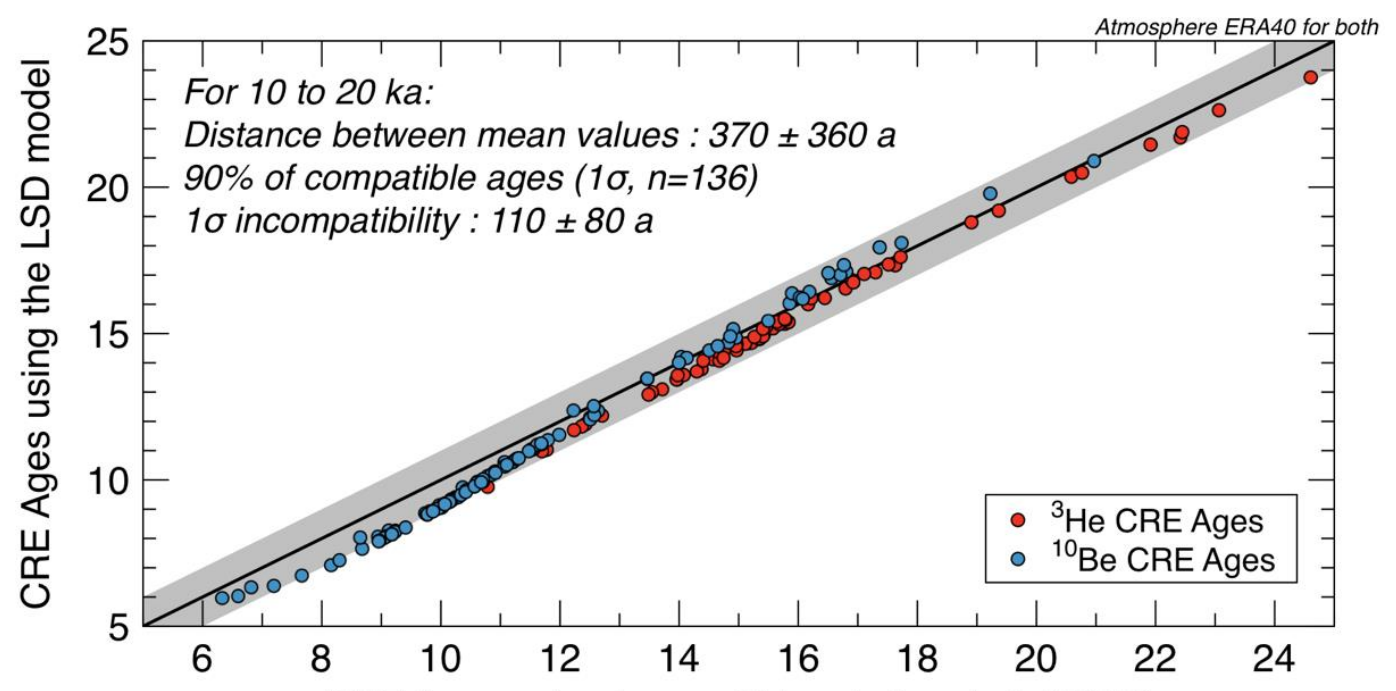

CRE Ages using Lm and Muscheler et al. (2005)

1508

1509

1510

1511

1512

1513

Figure S5. Comparison between two scaling procedures to compute CRE ages with the CREp online calculator (https://crep.otelo.univ-lorraine.fr). For this study, we used the Lm scaling model (Balco et al., 2008) and the geomagnetic database of Muscheler et al. (2005). We compare our results to those obtained using the LSD scaling model (Lifton et al., 2014) and the geomagnetic data compiled by Lifton (2016). We used the spatialized atmosphere ERA40 (Uppala et al., 2005) for both calculations 


\section{S.6. Illustration of the Bayesian filtering process on the age data}

$1515 \quad$ Figure S6 schematically illustrates how stratigraphic relations between moraines are used to 1516 filter the age PDFs.

1517

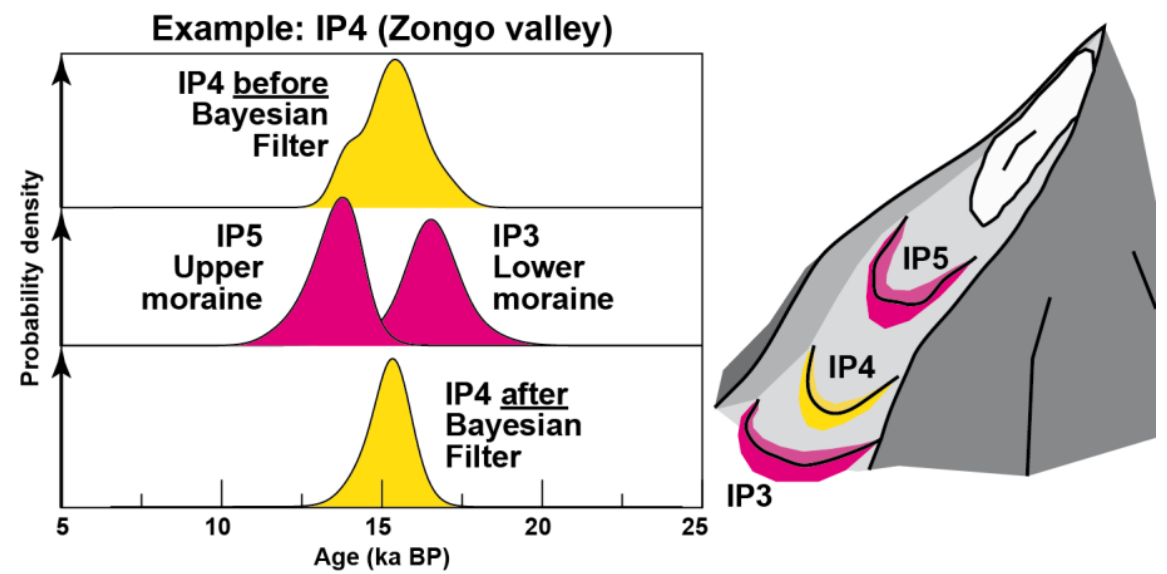

Figure S6. Illustration of the Bayesian filtering process in the case of moraine IP4 in Zongo Valley. The raw age distribution of the upper and lower moraines that stratigraphically bracket IP4 are used to filter the raw age distribution of IP4 and improve the accuracy of its age. 